\title{
A morphometric approach to conch ontogeny of Cymaclymenia and related genera (Ammonoidea, Late Devonian)
}

\author{
C. Klein and D. Korn \\ Museum für Naturkunde Berlin, Invalidenstraße 43, 10115 Berlin, Germany \\ Correspondence to: D. Korn (dieter.korn@mfn-berlin.de)
}

Received: 4 November 2013 - Revised: 17 December 2013 - Accepted: 14 January 2014 - Published: 20 February 2014

\begin{abstract}
Representatives of the Late Devonian ammonoid family Cymaclymeniidae were studied for their conch ontogeny. Two methods were applied: (1) the analysis of classical morphometric conch parameters and (2) an outline analysis of the aperture using elliptic Fourier analysis. Application of both methods leads to similar results, allowing a separation of some of the species by means of their ontogenetic pathways. The new species Procymaclymenia ebbighauseni n. sp., Cymaclymenia subvexa n. sp., Cymaclymenia formosa n. sp., Cymaclymenia lambidia n. sp., Cymaclymenia carnata n. sp., Cymaclymenia aulax n. sp., Cymaclymenia serotina $\mathrm{n}$. sp. and Postclymenia calceola n. sp. are described in the systematic part.
\end{abstract}

\section{Introduction}

The study of ontogeny is becoming more important to biological research, particularly when combined with evolutionary patterns. In this respect, the study of allometric growth (i.e. the deviation from equal proportions during growth) is an important task for the study of life histories and functional properties of many organisms. Huxley $(1924,1932)$ and Huxley and Teissier (1936) outlined the major principles of allometry. The three levels of allometry (static, ontogenetic and phylogenetic allometry) were characterised by Gould (1977), Cheverud (1982) and Klingenberg (1998). Accretionary growth of ammonoids with conservation of juvenile stages allows for the investigation of complete ontogenetic transformations of conch geometry and is particularly suitable for studying ontogenetic allometry (Korn, 2012).

Data for the study of ontogenetic allometry can be classified in two principal groups (Klingenberg, 1998): (1) "crosssectional data", in which individual specimens are measured at a single stage and (2) "longitudinal data", in which each individual is measured multiple times during growth. Only the second class makes it possible to assess the individual variability of ontogenetic allometry. Ammonoids can be regarded as excellent study objects for the acquisition of "longitudinal data" (Korn, 2012).

In the following we present a study on the morphological evolution of the family Cymaclymeniidae based on material from the Anti-Atlas of Morocco. Of the eight discriminated North African species of the family, six were analysed in terms of conch ontogeny using data acquired from conch cross sections.

\section{Allometric growth in ammonoids}

Gould (1966), Klingenberg and Froese (1991) and Klingenberg $(1996,1998)$ reviewed the principles of allometry. Allometry in the simplest form can be expressed by the power function

$y=b x^{a}$,

where $y$ is a variable (e.g. the width of an ammonoid conch), $x$ the reference parameter (e.g. the diameter of an ammonoid conch), $b$ a constant for the calculation (e.g. the ratio between conch width and conch diameter) and the allometry coefficient $a$ measures the deviation from isometry. Values of $a$ greater than 1 express positive allometry, and values of $a$ lower than 1 indicate negative allometry; they thus document different ontogenetic trajectories of $x$ and $y$. Isometry occurs where $a=1$.

Ammonoids usually possess planispiral conchs with perfect bilateral symmetry. The study of their growth including data acquisition can best be achieved using high-precision cross sections, i.e. cross sections meeting the protoconch (i.e. 

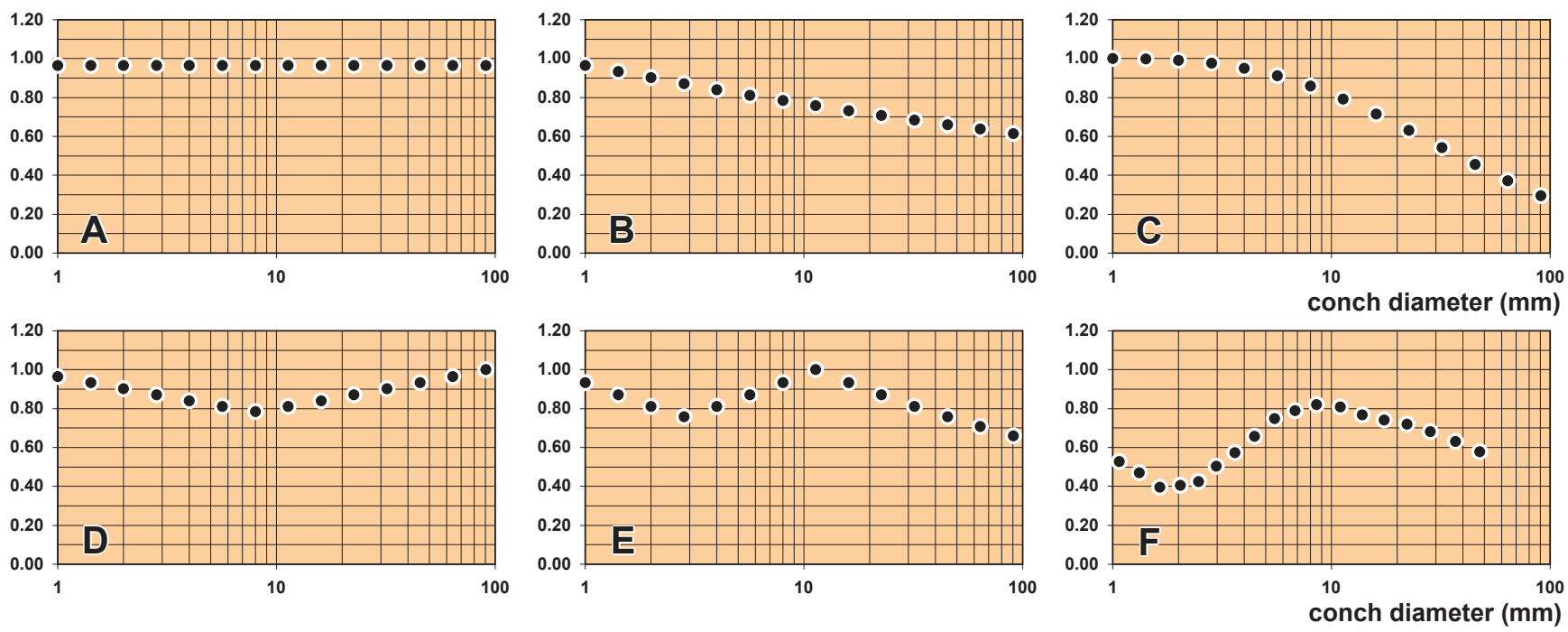

Figure 1. Modes of allometry expressed in ammonoid conchs, exemplified in the conch width index (CWI) of modelled and real ammonoids (Korn, 2012). (A) Isometry (stable allometry coefficient $\alpha=1$ ). (B) Monophasic linear allometry (stable $\alpha$; $\alpha<1$ ). (C) Monophasic nonlinear allometry (decreasing $\alpha$ ). (D) Biphasic linear allometry (succession of two different allometry coefficients $\alpha$ ). (E) Triphasic linear allometry (succession of three different allometry coefficients $\alpha$ ). (F) Triphasic non-linear allometry in the Early Carboniferous example Cravenoceras leion Bisat, 1930 (ontogenetically variable allometry coefficient $\alpha$ ).

the initial chamber of the conch that coincides with the centre of coiling) at its largest diameter. From such cross sections, two data sets can be obtained for each volution, meaning that growth increments of the conch spiral with a distance of 180 degrees can be studied. These growth increments are defined by the so-called Raupian conch parameters (Raup and Michelson, 1965; Raup, 1966, 1967; Korn and Klug, 2003, 2007; Korn, 2010) as well as by the shape of the aperture (e.g. Simon et al., 2010, 2011).

Palaeozoic ammonoids never show isometric growth. Linear allometry (i.e. growth with an invariable allometry constant $a$ ) is also very rare. Instead allometric growth in ammonoid conchs most frequently occurs not only with a dynamic $a$ but also with uncoupled changes of $a$ with respect to the different conch parameters (Fig. 1). Three modes of ontogenetic allometry can be seen in ammonoids: (1) monophasic allometry (which can be linear or non-linear), (2) biphasic allometry and (3) triphasic or polyphasic allometry (Kullmann and Scheuch, 1970; Kant, 1973). Each of the three cardinal conch parameters - conch width index (CWI), umbilical width index (UWI) and whorl expansion rate (WER) may display allometric growth. The combination of the three different modes of allometry expressed in the three conch parameters enables a large variety of ontogenetic trajectories realised within the Ammonoidea.

The Late Devonian Cymaclymenia is, in its adult conch geometry, a genus with a morphology that repeatedly occurs during the evolutionary history of the Ammonoidea; it represents the average conch morphology with respect to the three cardinal conch parameters. Furthermore, the genus belongs to those Palaeozoic ammonoids with moderately strong ontogenetic changes of the conch. However, just this "mediocrity" makes Cymaclymenia an interesting study object, because in this, some of the main principles of Palaeozoic ammonoid conch ontogeny can be investigated.

\section{Material}

\subsection{The family Cymaclymeniidae}

Towards the end of the Devonian and shortly before the extinction of the majority of ammonoid lineages at the Hangenberg event, the clymeniid ammonoids are characterised by occupation of a wide morphological spectrum. The morphological disparity of the clymeniids is expressed by a wide range of conch morphology (from serpenticonic to discoidal and globular shapes), suture lines (from extremely simple with only one wide lateral lobe to rather complex with a number of pointed lobes) and shell ornament (from absence of coarse ornament to ribs and spines). Cymaclymenia shows, in many respects, a morphology within the centre of the clymeniid morphospace.

Cymaclymenia is the geographically most widespread of all clymeniid genera with occurrences in a large number of places in central Europe, Spain, Great Britain, the South Urals, North Africa, Australia, etc.; it usually outnumbers all of the other genera in the late Famennian ammonoid assemblages. The genus Cymaclymenia contains about 20 species (Korn and Ilg, 2007), which are mainly separated be means of conch geometry and suture line 


\begin{tabular}{|c|c|c|c|c|c|c|}
\hline \multicolumn{2}{|c|}{$\begin{array}{l}\text { Chrono- } \\
\text { Stratigr. }\end{array}$} & \multicolumn{2}{|c|}{ Conodonts } & $\begin{array}{c}\text { Biostratigraphy } \\
\text { Ammonoids Rhenish Mts. }\end{array}$ & \multirow[t]{2}{*}{$\begin{array}{c}\text { Ammonoids } \\
\text { Anti-Atlas }\end{array}$} & $\begin{array}{c}\text { Cymaclymeniid } \\
\text { species }\end{array}$ \\
\hline & & sulcata & & Gattendorfia subinvoluta & & \multirow{26}{*}{ 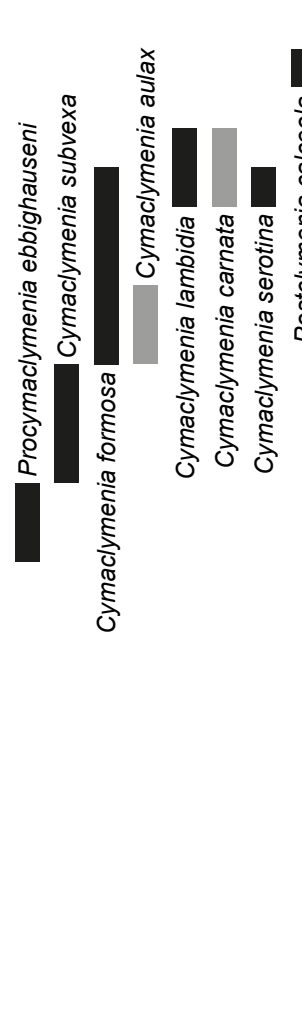 } \\
\hline \multirow{12}{*}{$\begin{array}{l}z \\
z \\
z\end{array}$} & \multirow{12}{*}{$\begin{array}{l}\text { Ш } \\
\vdash \\
\longleftarrow\end{array}$} & \multirow{6}{*}{ praesulcata } & Upper & Acutimitoceras prorsum & Acutimitoceras & \\
\hline & & & \multirow{2}{*}{ Middle } & Cymaclymenia nigra & & \\
\hline & & & & Wocklumeria sphaeroides & Wocklumeria & \\
\hline & & & \multirow{3}{*}{ Lower } & Parawocklumeria paradoxa & \multirow{2}{*}{ Parawocklumeria } & \\
\hline & & & & Kamptoclymenia endogona & & \\
\hline & & & & Effenbergia lens & \multirow{3}{*}{ Kalloclymenia } & \\
\hline & & \multirow{6}{*}{ expansa } & \multirow{2}{*}{ Upper } & Muessenbiaergia parundulata & & \\
\hline & & & & Muessenbiaergia sublaevis & & \\
\hline & & & \multirow{2}{*}{ Middle } & Piriclymenia piriformis & \multirow{3}{*}{ Gonioclymenia } & \\
\hline & & & & Ornatoclymenia ornata & & \\
\hline & & & \multirow{2}{*}{ Lower } & Clymenia laevigata & & \\
\hline & & & & Franconioclymenia serpentina & Endosiphonites & \\
\hline \multirow{7}{*}{ Ш } & & postera & $\begin{array}{l}\text { Upper } \\
\text { Lower }\end{array}$ & Protoxyclymenia dunkeri & \multirow{2}{*}{ Platyclymenia } & \\
\hline & & \multirow{3}{*}{ trachytera } & \multirow{2}{*}{ Upper } & Platyclymenia annulata & & \\
\hline & & & & Prolobites delphinus & Sulcoclymenia & \\
\hline & & & Lower & Pseudoclymenia pseudogoniatites & \multirow{2}{*}{ Planitornoceras } & \\
\hline & & \multirow{3}{*}{ marginifera } & Uppermost & Pernoceras dorsatum & & \\
\hline & \multirow{2}{*}{$\begin{array}{l}w \\
\square \\
0 \\
0 \\
\bar{\Sigma} \\
\Sigma\end{array}$} & & Upper & Maeneceras biferum & Maeneceras & \\
\hline & & & Lower & Paratornoceras lentiforme & \multirow{2}{*}{ Praemeroceras } & \\
\hline \multirow{5}{*}{\multicolumn{2}{|c|}{$\begin{array}{l}\nu \\
\\
\alpha \\
4 \\
\end{array}$}} & \multirow{2}{*}{ rhomboidea } & Upper & Praemeroceras petterae & & \\
\hline & & & $\begin{array}{l}\text { Lower } \\
\text { Uppermost }\end{array}$ & Paratorleyoceras globosum & Paratorleyoceras & \\
\hline & & crepida & $\begin{array}{l}\text { Upper } \\
\text { Middle }\end{array}$ & Cheiloceras subpartitum & \multirow{2}{*}{ Cheiloceras } & \\
\hline & & \multirow[b]{2}{*}{ triangularis } & $\begin{array}{l}\text { Lidaer } \\
\text { Lower } \\
\text { Upper }\end{array}$ & "Cheiloceras sp." & & \\
\hline & & & $\begin{array}{l}\text { Middle } \\
\text { Lower } \\
\end{array}$ & Phoenixites frechi & Phoenixites & \\
\hline 4 & نـ & linguiformis & & Crickites holzapfeli & Crickites & \\
\hline
\end{tabular}

Figure 2. Famennian biostratigraphy (based on Korn, 1999; Becker et al., 2002) with the approximate stratigraphic occurrences of the cymaclymeniid species in the Anti-Atlas of Morocco (T., Tournaisian; Fr., Frasnian).

(Korn, 1981). Cymaclymeniids occur throughout the late Famennian (Fig. 2), and the family provides rich study material.

The evolutionary lineage of the cymaclymeniids was the only one among the clymeniids that survived the global Hangenberg event near the Devonian-Carboniferous boundary (Korn et al., 2004), one of the most severe extinction events for the Ammonoidea. However, these failed survivors became extinct shortly after the event without descendants.

In the course of this project, we investigated eight species of cymaclymeniids, which were collected in outcrops in the Anti-Atlas of Morocco. A taxonomic revision of the species will be provided in the descriptive part. Six of the following species were studied (Fig. 3):

- Procymaclymenia ebbighauseni $\mathrm{n}$. sp.,

- Cymaclymenia subvexa $\mathrm{n}$. sp.,

- Cymaclymenia formosa n. sp.,

- Cymaclymenia lambidia $\mathrm{n}$. sp.,

- Cymaclymenia carnata $\mathrm{n}$. sp.,

- Cymaclymenia serotina $\mathrm{n}$. sp.,

- Cymaclymenia aulax $\mathrm{n} . \mathrm{sp}$.,

- Postclymenia calceola n. sp.
The three genera Cymaclymenia, Procymaclymenia and Postclymenia can be separated on the basis of their suture lines (Fig. 4). Procymaclymenia, as the stratigraphically oldest genus, possesses a small, blunt and nearly symmetric lateral lobe, while the lateral lobe in Cymaclymenia is strongly asymmetric and pointed on the ventral side. The stratigraphically youngest genus Postclymenia possesses a very large, strongly asymmetric lateral lobe.

\subsection{Origin of the study material}

All specimens of Cymaclymenia and related genera, on which this study is based, were collected in the eastern AntiAtlas of Morocco, which is known as a magnificent source of study material for long timescales (e.g. Petter, 1959, 1960). Marvellous outcrop conditions and good preservation of the fossils in this region serve as excellent preconditions for such a study. Furthermore, the palaeogeography (Wendt, 1985, 1988 ) and stratigraphy of the Famennian sedimentary succession (e.g. Korn, 1999; Becker et al., 2000, 2002) have been intensely studied and form a framework for further, more detailed investigations. 

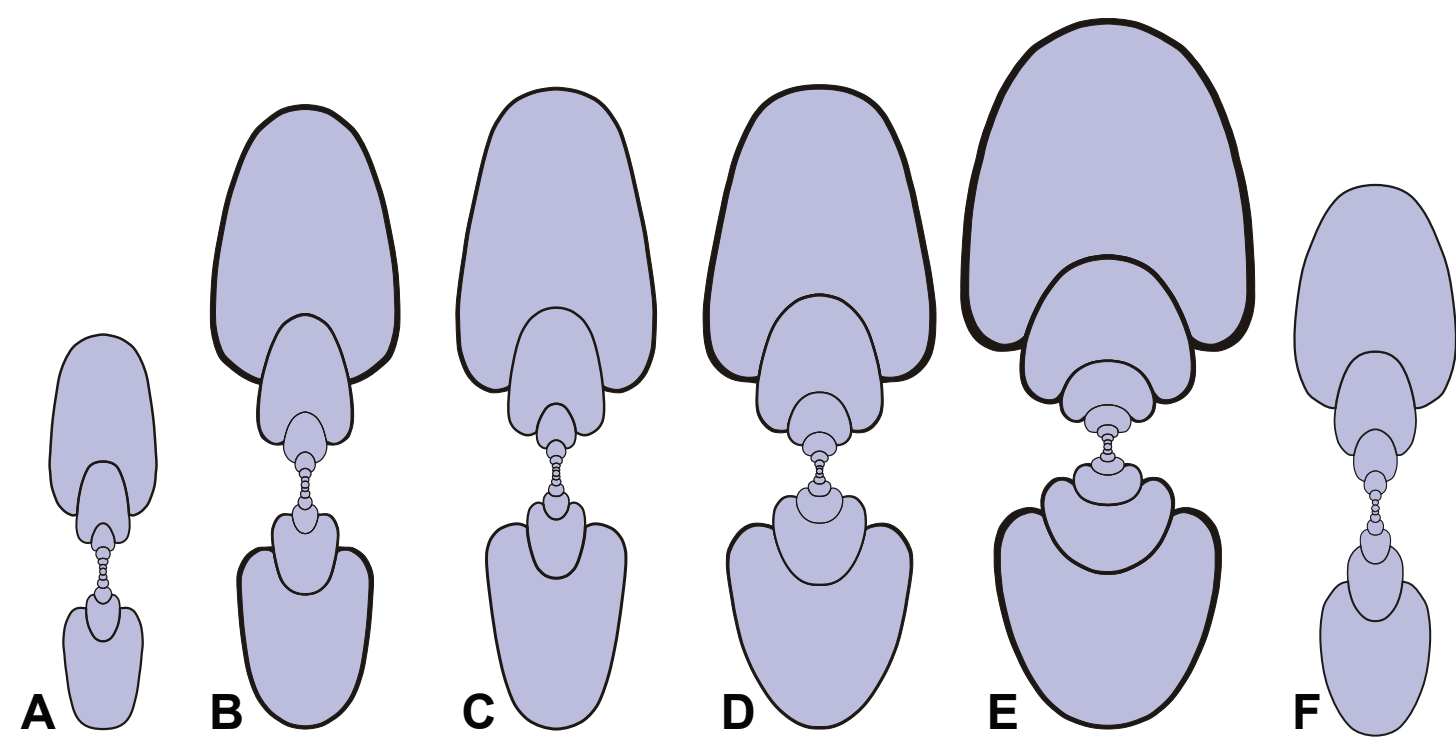

Figure 3. Cross sections of the six analysed cymaclymeniid ammonoids from the Anti-Atlas of Morocco; all $\times 1.5$. (A) Procymaclymenia ebbighauseni n. sp., paratype MB.C.22639 (Korn 1998 Coll.) from Madène el Mrakib. (B) Cymaclymenia subvexa n. sp., paratype MB.C.22675 (Wendt Coll.) from Bou Ifarherioun. (C) Cymaclymenia formosa n. sp., paratype MB.C.22649.3 (Korn 2009 Coll.) from Lambidia (Aguelmous). (D) Cymaclymenia lambidia n. sp., paratype MB.C.22632.3 (Korn 1998 Coll.) from Madène el Mrakib. (E) Cymaclymenia carnata n. sp., holotype MB.C.22654 (Kullmann Coll.) from Lambidia (Aguelmous). (F) Postclymenia calceola n. sp., paratype MB.C.9302.1 (Korn 2004 Coll.) from Lalla Mimouna.

The most important localities (Fig. 5), from which the studied material derived, are as follows (Appendix Table A1):

- Ouidane Chebbi (Tafilalt Basin),

- Bordj d'Erfoud, Bou Ifarherioun and El Atrous (Tafilalt Platform),

- Taourirt, Bou Tlidat, Lambidia and Madène el Mrakib (Ma'der Basin),

- Lalla Mimouna (Ma'der Platform).

\section{Methods}

\subsection{Principles of morphometrics}

Morphometrics is the quantitative description, analysis and interpretation of form and form modification in the field of biology. Bookstein (1991) characterised morphometrics as the science of covariance of biological form. The objects of morphometric studies are thus not the forms as such, but their interrelationships, origins and causes.

The comparison of anatomical properties of organisms has been a central theme in biology for centuries. In the early 20th century the analysis of morphology became increasingly quantitative (Bookstein, 1998), and the development of statistical methods such as the calculation of a correlation coefficient (Pearson, 1895), variance analysis (Fisher, 1935) and principal component analysis (PCA) (Pearson, 1901; Hotelling, 1933) led to a large number of analytical tools. In the traditional morphometrics, multivariant statistical analyses using quantitative sets of variables (e.g. length, width and height of distinct features) were applied. In the late 1980s and early 1990s, a change began towards "geometric morphometrics", in which geometric structures under interest were used for more complete analyses; these allowed for a regression of statistical results in geometric structures (Rohlf and Marcus, 1993; Adams et al., 2004; Mitteroecker and Gunz, 2009). The most widespread among the methods of geometric morphometrics is the analysis of landmarks and outlines, as achieved in the Fourier analysis (for reviews, see MacLeod, 2002; Adams et al., 2004).

\subsection{Data acquisition}

From digitised drawings of conch cross sections, three of the basic conch dimensions can immediately be obtained for each half volution (for a detailed description of the parameters, see Korn, 2012) (Fig. 6):

- conch diameter $(\mathrm{dm})$; for some calculations the $\log$ diameter $\left(\mathrm{dm}_{\log }\right)$ is used here,

- whorl width (ww),

- whorl height (wh).

Using these basic conch dimensions, secondary dimensions (in $\mathrm{mm}$ ) can be computed as follows: 


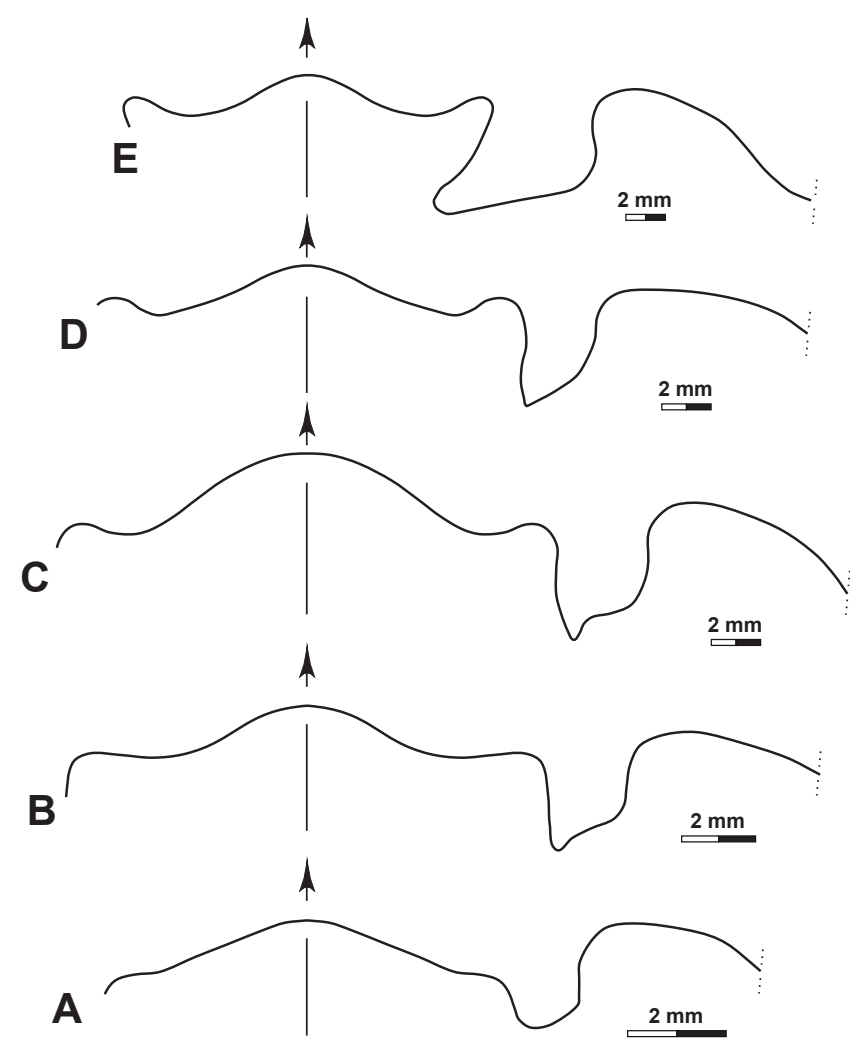

Figure 4. Suture lines of cymaclymeniid ammonoids from the Anti-Atlas of Morocco. (A) Procymaclymenia ebbighauseni n. sp., paratype MB.C.22620.1 (Ebbighausen and Korn 2009 Coll.) from Madène el Mrakib; at $19.5 \mathrm{mmdm}, 8.8 \mathrm{~mm} w h, \times 5.0$. (B) $C y$ maclymenia subvexa n. sp., paratype MB.C.22636.1 (Korn 1998 Coll.) from Madène el Mrakib; at $30.5 \mathrm{~mm} \mathrm{dm}, 13.8 \mathrm{~mm} w \mathrm{~h}$, $\times$ 3.75. (C) Cymaclymenia formosa n. sp., paratype MB.C.22669.4 (Wendt Coll.) from Hamar Laghdad; at $40.5 \mathrm{~mm} \mathrm{dm}, 19.8 \mathrm{~mm}$ wh, $\times 2.5$. (D) Cymaclymenia lambidia n. sp., paratype MB.C. 22677 (Wendt Coll.) from Aguelmous; at $39.3 \mathrm{~mm} \mathrm{dm}, 18.4 \mathrm{~mm} w \mathrm{w}$, $\times 2.5$. (E) Postclymenia calceola n. sp., holotype MB.C.22662.1 (Ebbighausen 2005 Coll.) from Lalla Mimouna; at $53.5 \mathrm{~mm} \mathrm{dm}$, $23.4 \mathrm{~mm}$ wh, $\times 2.0$.

- umbilical width (uw) $=\left(\mathrm{dm}-\mathrm{wh}_{1}-\mathrm{wh}_{2}\right)(=$ conch diameter minus the whorl height of the last volution and the volution 180 degrees before),

- apertural height $(\mathrm{ah})=\left(\mathrm{dm}_{1}-\mathrm{dm}_{2}\right)(=$ largest conch diameter minus the conch diameter 180 degrees before).

Conch proportions and expansion rates (growth rates) were calculated in the following way by using the three basic conch dimensions (these are called conch parameters in the following):

- conch width index $(\mathrm{CWI})=\mathrm{ww} / \mathrm{dm}$,

- umbilical width index $(\mathrm{UWI})=\mathrm{uw} / \mathrm{dm}$ or $\left(\mathrm{dm}_{1}-\mathrm{wh}_{1}-\right.$ $\left.\mathrm{wh}_{2}\right) / \mathrm{dm}_{1}$,
- whorl width index $(\mathrm{WWI})=\mathrm{ww} / \mathrm{wh}$,

- whorl expansion rate $($ WER $)=\left(\mathrm{dm}_{1} / \mathrm{dm}_{2}\right)^{2}$ or

$\left[\mathrm{dm}_{1} /\left(\mathrm{dm}_{1}-\mathrm{ah}\right)\right]^{2}$ (= squared quotient of the largest conch diameter and the conch diameter 180 degrees before).

\subsection{Analysis of data}

\section{Outline tracing and Fourier analysis}

In the outline analysis in geometric morphometrics, as used in the Fourier analysis, points along a contour are digitised (Adams et al., 2004). For the analysis of conch cross sections, we therefore produced outline images for each half whorl of all growth stages larger than $1 \mathrm{~mm}$ conch diameter; the earliest stages below $1 \mathrm{~mm}$ diameter were excluded because of the large impact of minor measurement error. Data collection was done using the program tpsDig (Rohlf, 2006); we used 500 coordinates for each outline (Simon et al., 2010).

Fourier analysis is probably the most frequently used method for outline analyses (Wills, 2001); for the analysis of complex forms, the use of the elliptical Fourier analysis is required (Kuhl and Giardinia, 1982; Ferson et al., 1985; Temple, 1992; Crampton, 1995; Haines and Crampton, 2000). The transformation of the outline data into periodical functions is here achieved by the programs hangle and hmatch, in which 22 Fourier coefficients were calculated (Simon et al., 2010, 2011). Using these Fourier coefficients, the curves are analysed by a principal component analysis (Adams et al., 2004).

\section{Results}

\subsection{Ontogenetic trajectories of the analysed species}

For the graphic visualisation of the ontogenetic trajectories, we produced diagrams that show the conch diameter on the $x$ axis (as log values according to the logarithmic growth of ammonoid conchs) and the conch parameters (CWI, UWI and WER) on the $y$ axis (Fig. 7 using the example of $C y$ maclymenia lambidia). These diagrams demonstrate that the conchs of Cymaclymenia and related genera deviate from isometric growth (in which the parameters would always have the same value). Allometric growth is the rule, and the allometry is non-linear with the separation of distinct phases.

The illustration of conch proportions and expansion rates in bivariate plots (with the diameter of the conch on the $x$ axis) allows the detection of the following ontogenetic trends, which are shared by all investigated species of the family Cymaclymeniidae:

- All of the three conch parameters CWI, UWI and WER show allometric development; the adult conchs differ more or less significantly from the juveniles.

- Almost none of these parameters show linear allometry; biphasic or triphasic ontogenetic trajectories are 


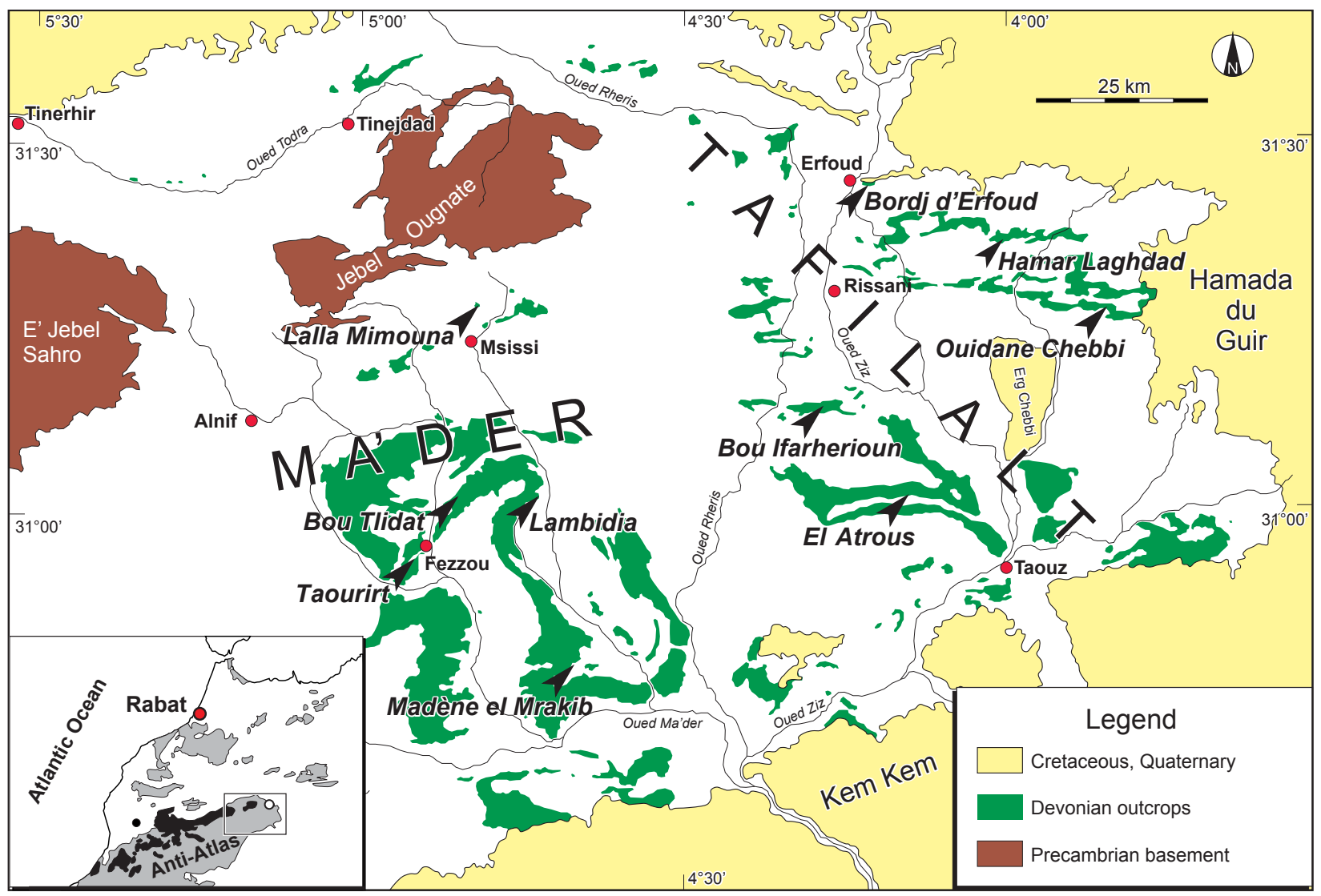

Figure 5. Geological map of the eastern Anti-Atlas of Morocco with the most important localities of cymaclymeniid ammonoids.

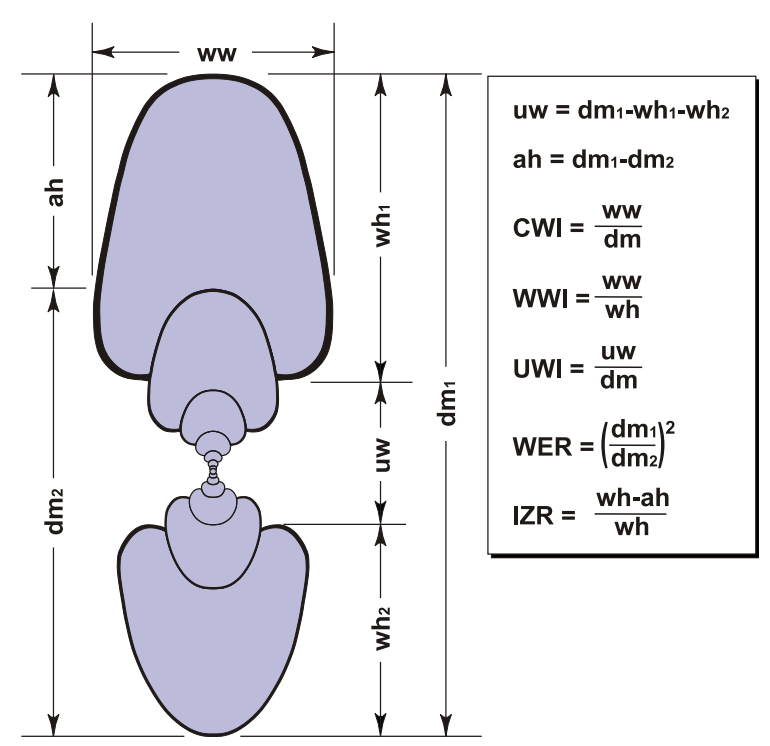

Figure 6. Conch dimensions, conch proportions and expansion rates (growth rates) obtained from ammonoid conch cross sections. predominant. This means that the allometry coefficient $a$ changes during ontogeny.

- CWI and UWI generally decrease during ontogeny; however, the rates differ between the various species.

- In all species, the largest relative umbilical width (UWI $=0.35-0.50)$ occurs in the early juvenile stage between 2 and $4 \mathrm{~mm}$ conch diameter. Thereafter the UWI decreases in the intermediate stage; the adult stage is often characterised by a stable UWI.

- The WER decreases in early ontogeny (to 1.80 at $2-3 \mathrm{~mm}$ conch diameter) and increases later in ontogeny.

In the general ontogenetic trends, Cymaclymenia and its relatives resemble the majority of Palaeozoic ammonoids. The investigated species share some common characters with respect to their conch ontogeny, but they also show differences, which allow for a separation (Table 1).

\subsection{Morphological disparity of the metric conch parameters}

The morphometric data of the cardinal conch parameters (CWI, UWI, WER) of the cymaclymeniid conch cross sections were analysed using a principal component analysis (PCA). In this analysis, only growth stages larger than $1 \mathrm{~mm}$ 

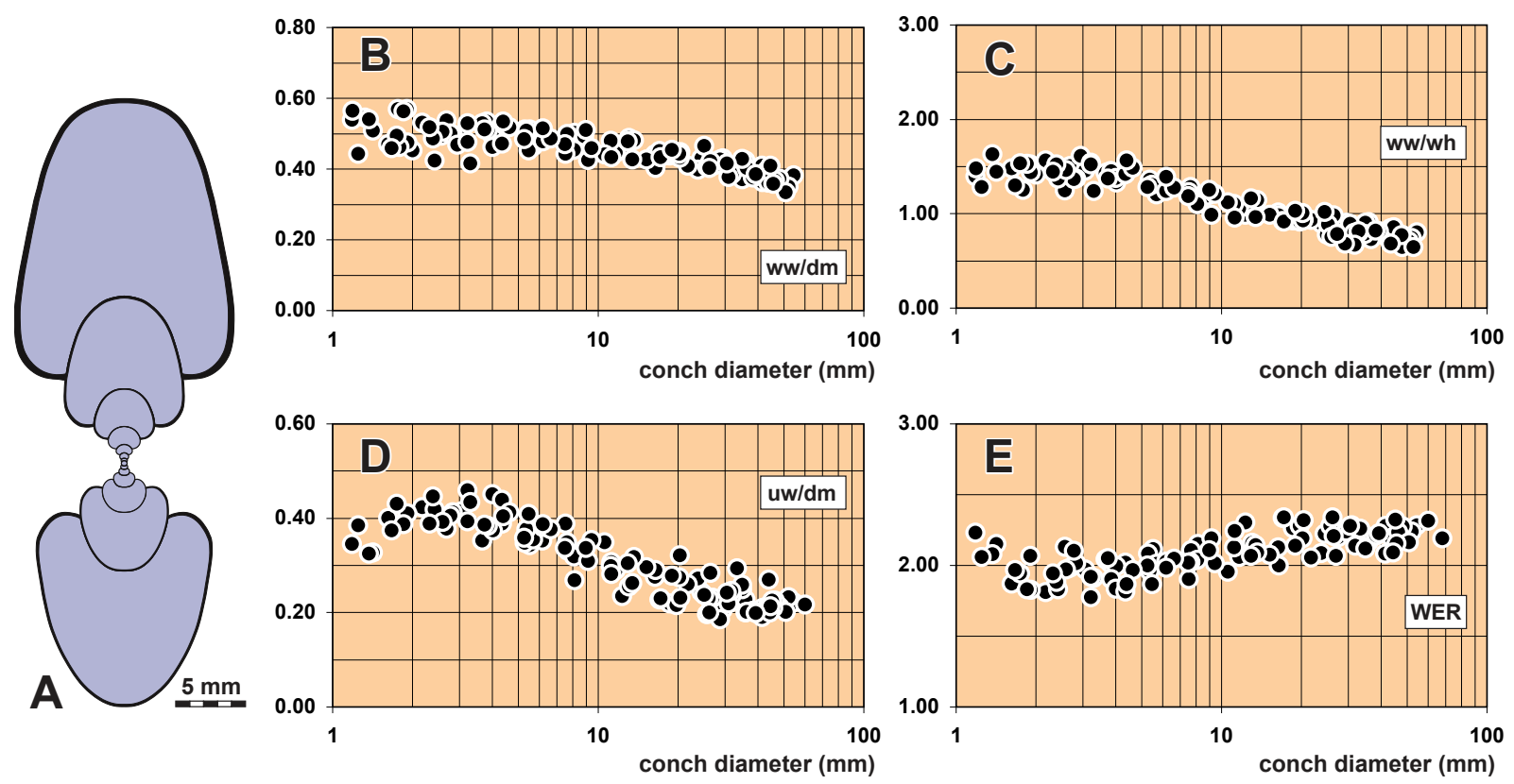

Figure 7. Ontogenetic trajectories of the four cardinal conch parameters conch width index $(\mathrm{CWI}=\mathrm{ww} / \mathrm{dm})$, whorl width index $(\mathrm{WWI}=\mathrm{ww} / \mathrm{wh})$, umbilical width index $(\mathrm{UWI}=\mathrm{uw} / \mathrm{dm})$ and whorl expansion rate $(\mathrm{WER})$ in Cymaclymenia lambidia.

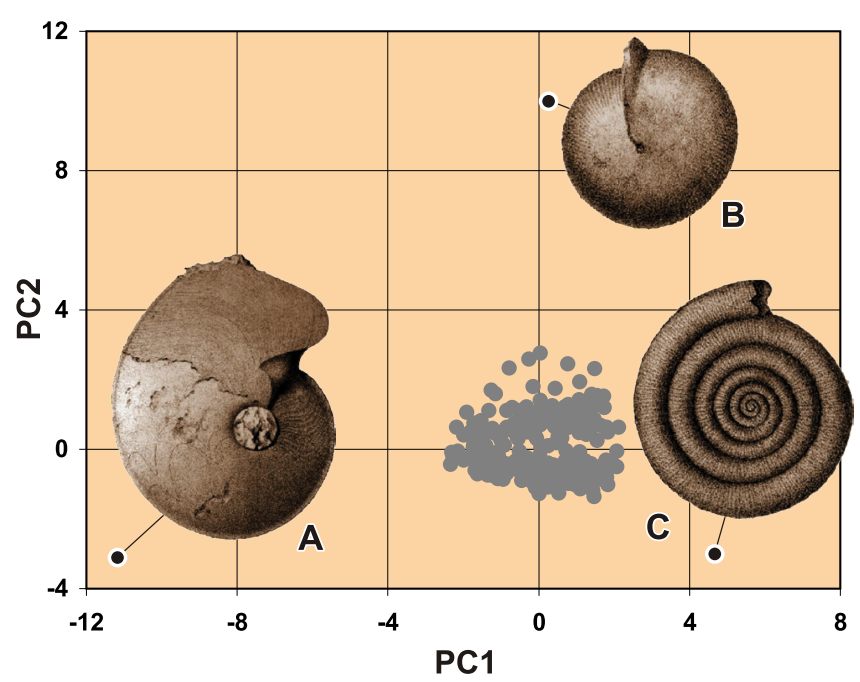

Figure 8. Morphospace of cymaclymeniid specimens (grey dots) in the scatter plot of the first two PCA axes. Three examples of Devonian ammonoids ranging in the corners of the triangular total morphospace are shown: (A) Carinoceras as a slender, involute ammonoid with high aperture, (B) Prolobites as a globular, involute ammonoid with low aperture and (C) Phenacoceras as a slender, evolute ammonoid with low aperture.

were included. Additionally to the cymaclymeniids, three extreme morphologies of the Devonian ammonoids are included to point at the range and position of the cymaclymeniids in the total morphospace (Fig. 8). The analysis used the correlation mode; of the three resulting PCA axes,
PC1 expresses $56.8 \%$ (negative values refer to a reduction of the UWI and increasing WER values) of variation and PC2 expresses $35.6 \%$ (positive values refer to increasing CWI values).

In the triangular morphospace of the Devonian ammonoids (Korn and Klug, 2012), the growth stages of cymaclymeniids cover only a relatively small area (Fig. 8). This means that their juvenile and adult stages show a limited morphological range when compared with extreme morphologies. All investigated specimens show a migration within the morphospace with a loop in early ontogeny and later a migration along the $x$ axes from positive to negative values. The latter reflects a morphological development from widely umbilicate juvenile conchs with a low aperture towards narrowly umbilicate, discoidal or pachyconic conchs with a higher aperture. Differences between the genera and species are mainly expressed in the conch width index (expressed by variations in the $y$ axis) and the timing of developmental events such as changes in allometry.

The occupied areas of the six species display some overlap; a clear separation of the species within the scatter plot is thus not possible (Fig. 9).

The studied species show different ontogenetic pathways in the scatter plot of the PCA diagram, demonstrating the most important differences in conch ontogeny:

- Cymaclymenia carnata is the widest form and therefore has a position at the upper margin of the scatter plot with high values in PC2. Cymaclymenia lambidia has an intermediate position, and the four species Cymaclymenia subvexa, 
Table 1. Ontogenetic trajectories of the analysed species.

\begin{tabular}{|c|c|c|c|}
\hline & CWI & UWI & WER \\
\hline $\begin{array}{l}\text { Procymaclymenia } \\
\text { ebbighauseni } \mathrm{n} . \mathrm{sp} .\end{array}$ & $\begin{array}{l}\text { biphasic: (1) decrease from } 0.50 \\
(1 \mathrm{~mm} \mathrm{dm}) \text { to } 0.30(4 \mathrm{~mm}) \text {; } \\
\text { (2) stable until } 33 \mathrm{~mm} \mathrm{dm}\end{array}$ & $\begin{array}{l}\text { biphasic: (1) increase from } 0.30 \\
\text { ( } 1 \mathrm{~mm} \mathrm{dm}) \text { to } 0.50(3.5 \mathrm{~mm} \mathrm{dm}) \text {; } \\
\text { (2) decrease to } 0.23 \text { at } 33 \mathrm{~mm} \mathrm{dm}\end{array}$ & $\begin{array}{l}\text { triphasic: (1) decrease from } 2.20 \\
(1 \mathrm{~mm} \mathrm{dm}) \text { to } 1.90(2.5 \mathrm{~mm} \mathrm{dm}) \text {; } \\
\text { (2) increase to } 2.25(16 \mathrm{~mm} \mathrm{dm}) \text {; } \\
\text { (3) stable until } 33 \mathrm{~mm} \mathrm{dm}\end{array}$ \\
\hline
\end{tabular}

\begin{tabular}{|c|c|c|c|}
\hline $\begin{array}{l}\text { Cymaclymenia } \\
\text { subvexa } \mathrm{n} . \mathrm{sp} .\end{array}$ & $\begin{array}{l}\text { biphasic: (1) decrease from } \\
0.42-0.52(1 \mathrm{~mm} \mathrm{dm}) \text { to } 0.25- \\
0.40(4 \mathrm{~mm} \mathrm{dm}) ;(2) \text { stable } \\
\text { until } 50 \mathrm{~mm} \mathrm{dm}\end{array}$ & $\begin{array}{l}\text { triphasic: (1) increase from } 0.30 \\
(1 \mathrm{~mm} \mathrm{dm}) \text { to } 0.45(3 \mathrm{~mm} \mathrm{dm}) ; \\
\text { (2) decrease to } 0.20-0.35 \\
(25 \mathrm{~mm} \mathrm{dm}) ;(3) \text { stable until } \\
50 \mathrm{~mm} \mathrm{dm}\end{array}$ & $\begin{array}{l}\text { triphasic: }(1) \text { decrease from } 2.25 \\
(1 \mathrm{~mm} \mathrm{dm}) \text { to } 1.75(2.5 \mathrm{~mm} \mathrm{dm}) \text {; } \\
\text { (2) continuous increase to } 2.20-2.50 \\
(20 \mathrm{~mm} \mathrm{dm}) ;(3) \text { slight decrease to } \\
2.00-2.30(50 \mathrm{~mm} \mathrm{dm})\end{array}$ \\
\hline
\end{tabular}

\begin{tabular}{|c|c|c|c|}
\hline $\begin{array}{l}\text { Cymaclymenia } \\
\text { formosa } \mathrm{n} . \mathrm{sp} .\end{array}$ & $\begin{array}{l}\text { triphasic: }(1) \text { decrease from } \\
0.42-0.52(1 \mathrm{~mm} \mathrm{dm}) \text { to } 0.30- \\
0.40(4 \mathrm{~mm} \mathrm{dm}) ;(2) \text { stable until } \\
30 \mathrm{~mm} \mathrm{dm} ;(3) \text { slight decrease to } \\
0.25-0.30(55 \mathrm{~mm} \mathrm{dm})\end{array}$ & $\begin{array}{l}\text { triphasic: (1) increase from } 0.30 \\
(1 \mathrm{~mm} \mathrm{dm}) \text { to } 0.50(3 \mathrm{~mm} \mathrm{dm}) \\
(2) \text { decrease to } 0.20-0.30 \\
(25 \mathrm{~mm} \mathrm{dm}) ;(3) \text { stable until } \\
55 \mathrm{~mm} \mathrm{dm}\end{array}$ & $\begin{array}{l}\text { triphasic: (1) decrease from } 2.25 \\
(1 \mathrm{~mm} \mathrm{dm}) \text { to } 1.75(2.5 \mathrm{~mm} \mathrm{dm}) ; \\
(2) \text { continuous increase to } 2.25-2.50 \\
(30 \mathrm{~mm} \mathrm{dm}) ;(3) \text { slight decrease to } \\
2.00-2.25(55 \mathrm{~mm} \mathrm{dm})\end{array}$ \\
\hline $\begin{array}{l}\text { Cymaclymenia } \\
\text { lambidia } \mathrm{n} . \mathrm{sp} \text {. }\end{array}$ & $\begin{array}{l}\text { monophasic: }(1) \text { decrease from } \\
0.45-0.55(1 \mathrm{~mm} \mathrm{dm}) \text { to } 0.35- \\
0.40(60 \mathrm{~mm} \mathrm{dm})\end{array}$ & $\begin{array}{l}\text { triphasic: }(1) \text { increase from } 0.35- \\
0.40(1 \mathrm{~mm} \mathrm{dm}) \text { to } 0.40-0.45 \\
(3 \mathrm{~mm} \mathrm{dm}) ;(2) \text { decrease to } 0.20- \\
0.30(26-30 \mathrm{~mm} \mathrm{dm}) ;(3) \text { stable } \\
\text { until } 60 \mathrm{~mm} \mathrm{dm}\end{array}$ & $\begin{array}{l}\text { biphasic: (1) decrease from } 2.25 \\
(1 \mathrm{~mm} \mathrm{dm}) \text { to } 1.80 \text { ( } 2 \mathrm{~mm} \mathrm{dm}) \text {; } \\
\text { (2) continuous increase to } 2.25 \\
(60 \mathrm{~mm} \mathrm{dm})\end{array}$ \\
\hline $\begin{array}{l}\text { Cymaclymenia } \\
\text { carnata } \mathrm{n} . \mathrm{sp} .\end{array}$ & $\begin{array}{l}\text { biphasic: }(1) \text { increase from } \\
0.50(1 \mathrm{~mm} \mathrm{dm}) \text { to } 0.60-0.70 \\
(7 \mathrm{~mm} \mathrm{dm}) ;(2) \text { decrease to } 0.40 \\
(48 \mathrm{~mm} \mathrm{dm})\end{array}$ & $\begin{array}{l}\text { triphasic: (1) stable juvenile } \\
\text { stage (UWI }=0.40 \text { between } 1 \\
\text { and } 4 \mathrm{~mm} \mathrm{dm}) ;(1) \text { decrease to } \\
0.20(20 \mathrm{~mm} \mathrm{dm}) ;(3) \text { stable until } \\
48 \mathrm{~mm} \mathrm{dm}\end{array}$ & $\begin{array}{l}\text { biphasic: (1) decrease from } 2.00 \\
\text { ( } 1 \mathrm{~mm} \mathrm{dm}) \text { to } 1.80 \text { ( } 2.5 \mathrm{~mm} \mathrm{dm}) ; \\
\text { (2) continuous increase to } 2.20-2.40 \\
\text { ( } 48 \mathrm{~mm} \mathrm{dm})\end{array}$ \\
\hline $\begin{array}{l}\text { Postclymenia } \\
\text { calceola } \mathrm{n} . \mathrm{sp} .\end{array}$ & $\begin{array}{l}\text { biphasic: (1) rapid decrease } \\
\text { from } 0.40(1 \mathrm{~mm} \mathrm{dm}) \text { to } 0.30 \\
(1.7 \mathrm{~mm} \mathrm{dm}) ;(2) \text { nearly stable } \\
\text { until } 42 \mathrm{~mm} \mathrm{dm}\end{array}$ & $\begin{array}{l}\text { biphasic: (1) increase from } 0.35 \\
(1 \mathrm{~mm} \mathrm{dm}) \text { to } 0.45(4 \mathrm{~mm} \mathrm{dm}) \\
(2) \text { slight decrease from } 0.35- \\
0.45(4.5 \mathrm{~mm} \mathrm{dm}) \text { to } 0.30-0.35 \\
(42 \mathrm{~mm} \mathrm{dm})\end{array}$ & $\begin{array}{l}\text { biphasic: (1) decrease from } 2.30 \\
\text { (1 mm dm) to } 1.80-2.10 \\
(2.3 \mathrm{~mm} \mathrm{dm}) ;(2) \text { nearly stable } \\
\text { until } 42 \mathrm{~mm} \mathrm{dm}\end{array}$ \\
\hline
\end{tabular}

Cymaclymenia formosa, Procymaclymenia ebbighauseni and Postclymenia calceola are, because of their slender conch width, at the lower margin (negative values in PC2).

- Procymaclymenia ebbighauseni, Cymaclymenia subvexa, as well as Cymaclymenia formosa show very similar ontogenetic pathways and cannot be separated from each other. Postclymenia calceola differs from these species in the shortened ontogeny, which does not express the terminal, more narrowly umbilicate stage. Adult specimens of Postclymenia calceola occupy an area in the morphospace, which is typical for intermediate stages of the three species of Cymaclymenia.

\subsection{Morphological disparity of outline shapes (Fourier analysis)}

For a comparison with the results gained in the morphometric analysis, we achieved an alternative method for the depiction of the morphological changes in conch ontogeny the analysis of outline shapes in an elliptic Fourier analysis
(Crampton, 1995; Haines and Crampton, 2000; Simon et al., 2010). The analysis used the variation-covariation mode; of the resulting PCA axes, PC1 expresses $44.7 \%$ of variation and PC2 expresses $19.6 \%$.

We illustrate a second morphospace based on a Fourier analysis of the outline shapes with subsequent PCA (Fig. 10). In this diagram illustrating the first two axes of the PCA, all ontogenetic trajectories migrate along the $x$ axes from positive to negative values. It is striking that in juvenile and adult stages, all species are plotted in similar areas, while the intermediate stages show the largest differences between the species. Another striking fact is that the PCA scatter plots of the morphometric data and the outline data closely resemble each other. Cymaclymenia carnata has a position at the upper margin of the occupied morphospace (e.g. with highest $y$ values), followed downwards by Cymaclymenia lambidia, $C y$ maclymenia formosa, Cymaclymenia subvexa, Procymaclymenia ebbighauseni and Postclymenia calceola, which have a position at the lower margin of the morphospace (negative PC2 values). 

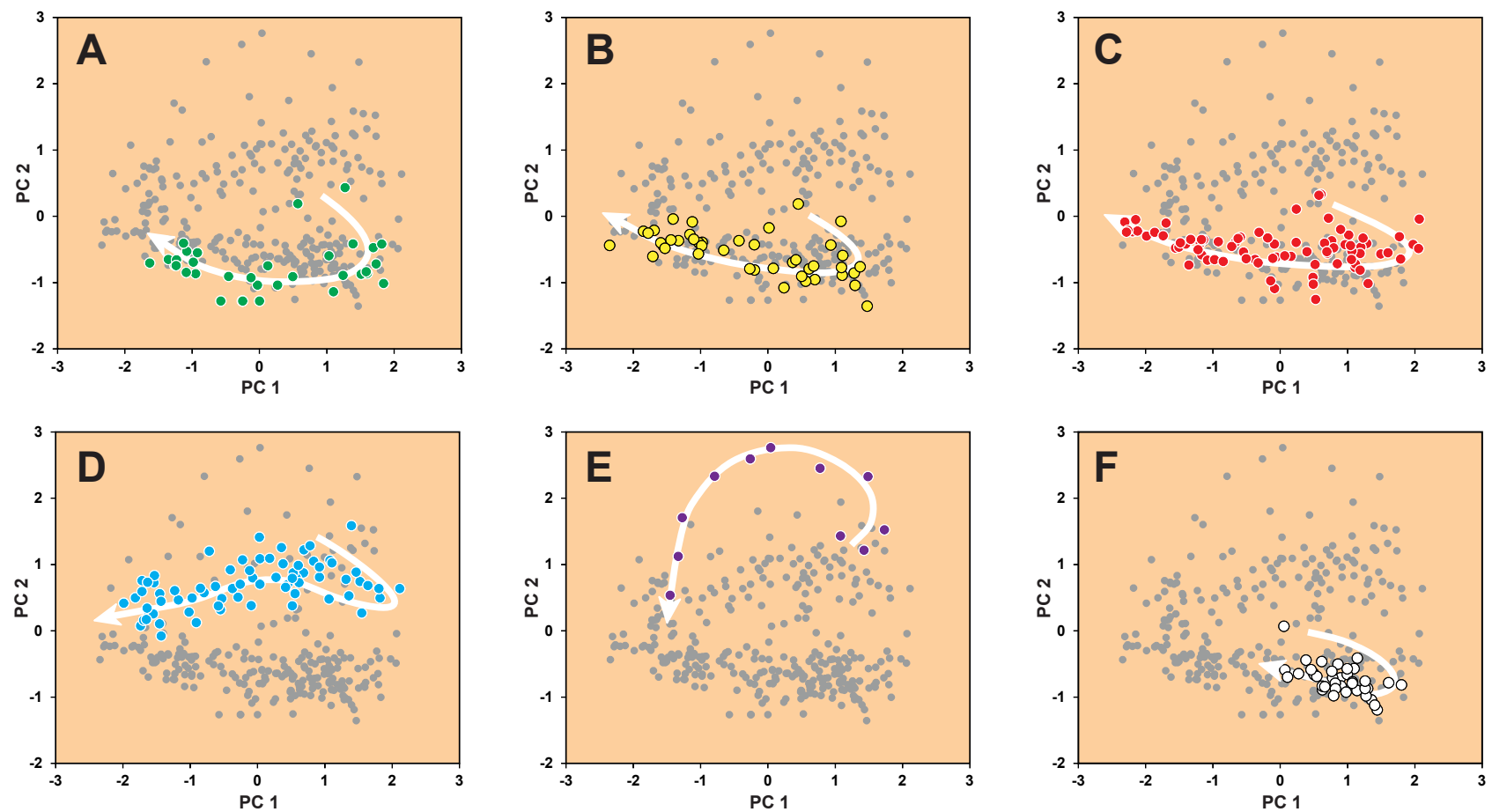

Figure 9. Ontogenetic pathways of six cymaclymeniid species in the morphospace calculated with morphometric data: (A) Procymaclymenia ebbighauseni n. sp., (B) Cymaclymenia subvexa n. sp., (C) Cymaclymenia formosa n. sp., (D) Cymaclymenia lambidia n. sp., (E) Cymaclymenia carnata n. sp. and (F) Postclymenia calceola n. sp.

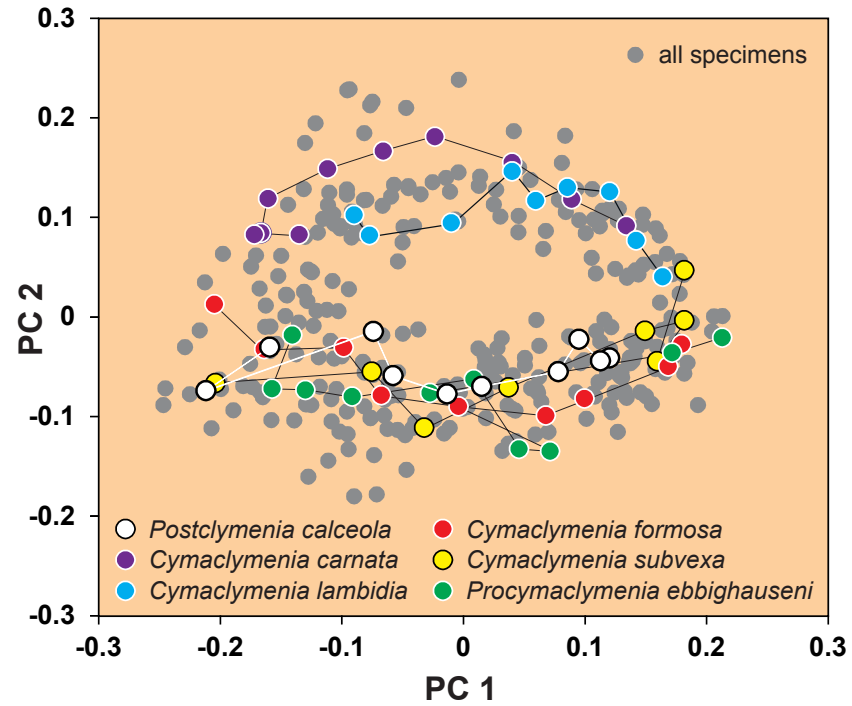

Figure 10. Ontogenetic pathways of six cymaclymeniid species in the morphospace calculated by data using an elliptical Fourier analysis of cross-section shapes.

\section{Discussion}

\subsection{Characters for the separation of species}

The studied conch parameters CWI, WWI, UWI and WER allow for a clear separation of cymaclymeniid species (for the dimensions and conch proportions, see Appendix Table A2). This is confirmed by very similar results gained by the analysis of the metric data and the Fourier data. The analysis of the metric data allows for a separation of five of the species. Procymaclymenia ebbighauseni, Cymaclymenia subvexa and Cymaclymenia formosa are morphologically very similar and therefore hardly separable by morphometric data. A separation of these species is mainly possible by the suture line (Fig. 4).

Cymaclymenia carnata and Cymaclymenia lambidia can be separated from the four species Cymaclymenia formosa, Cymaclymenia subvexa, Procymaclymenia ebbighauseni as well as Postclymenia calceola by the conch width index (CWI or ww /dm). Postclymenia calceola can easily be separated from Cymaclymenia formosa and Cymaclymenia subvexa because Postclymenia calceola is the only one of the analysed species that is widely umbilicate throughout ontogeny. Cymaclymenia formosa and Cymaclymenia subvexa can probably not be separated by means of outline analysis. 


\subsection{Ontogenetic and phylogenetic implications}

The three analysed cymaclymeniid genera have a successive stratigraphic occurrence, but this criterion alone does not mean that they represent a phyletic lineage. According to the increasing complexity of the suture lines, however, it may be postulated that a general lineage from Procymaclymenia over Cymaclymenia and finally Postclymenia is most plausible. However, closer relationships between the analysed species cannot be solved here. As we analysed material from the Anti-Atlas of Morocco only, possible immigrations from other regions may have contributed to the evolution of the lineage.

All investigated species are characterised by very similar ontogenetic trajectories; differences can be seen mainly in the conch width index (CWI) of the three species Cymaclymenia carnata, Cymaclymenia lambidia and Cymaclymenia subvexa. The latter, Cymaclymenia formosa and Procymaclymenia ebbighauseni, do not differ in this respect. This means that, if Cymaclymenia is derived from Procymaclymenia, changes in the ontogenetic trajectories are not traceable and thus not valuable for phylogeny. The two genera are separated by their suture line, which in Cymaclymenia is more derived with a strongly asymmetric, pointed lateral lobe.

Postclymenia calceola, the stratigraphically youngest species, shows a similar CWI like Cymaclymenia formosa and Procymaclymenia ebbighauseni, but does not reach the narrowly umbilicate adult stage like the genera Cymaclymenia and Procymaclymenia; instead it remains in the widely umbilicate stage characteristic of specimens of intermediate size of the other two genera. This shortening of morphological development by the loss of the adult stage, but by maintenance of size, can be regarded as a heterochronic process leading to neoteny (McNamara, 1986). An ontogenetic recapitulation of phylogeny is thus not present in this case.

\section{Systematic descriptions (D. Korn)}

Cymaclymenia is one of the most widespread clymeniid genera and often occurs in large numbers of individuals. It is thus an important genus for the investigation of provincialism and cosmopolitism. However, before detailed global comparison can be made, it is important to answer the following questions:

- How many species of Cymaclymenia (and closely related genera) are possibly represented in existing collections?

- What are the geographic ranges of the various species?

- Does provincialism or cosmopolitism dominate the geographic distribution?

- Are trends in the morphological evolution within the Cymaclymeniidae parallel in the various occurrences?
The regions from which species of Cymaclymenia and related genera have been described are listed here (Pr.: Procymaclymenia, $C$.: Cymaclymenia, Lam.: Laminoclymenia, Lag.: Laganoclymenia, R.: Rodachia, Po.: Postclymenia):

- Cornwall (England): C. quadrifera (McCoy, 1851), C. sagittalis (McCoy, 1851), C. constricta Selwood, 1960, C. globosa Selwood, 1960;

- Cantabrian Mountains (Spain): C. cyrtostriata (Kullmann, 1960);

- Rhenish Mountains (Germany): C. costata (Wedekind, 1908), C. cordata Wedekind, 1914, C. serpentina Schmidt, 1924, Po. evoluta Schmidt, 1924, C. involvens Lange, 1929, P. euryomphala (Schindewolf, 1937), C. warsteinensis Korn, 1979, C. nephroides Korn, 1981, C. nigra Korn, 1991;

- Thuringia (Germany): C. interpres (Schindewolf, 1923);

- Franconia (Germany): C. costellata (Münster, 1832), C. plana (Münster, 1832), C. semistriata (Münster, 1832), C. striata (Münster, 1832), R. dorsocostata (Münster, 1840), C. dorsonodosa (Münster, 1842), C. camerata Schindewolf, 1923;

- Lower Silesia (Poland): C. silesiaca (Renz, 1914), C. sudetica (Renz, 1914);

- Holy Cross Mountains (Poland): C. patula Czarnocki, 1989, Pr. pudica (Czarnocki, 1989), C. sulcata Czarnocki, 1989, Pr. fundilobata (Czarnocki, 1989), Pr. inflata (Czarnocki, 1989);

- South Urals (Russia): C. barbarae (Loewinson-Lessing, 1892), C. crenata (Nikolaeva and Bogoslovsky, 2005), C. decorata Nikolaeva and Bogoslovsky, 2005, C. fabra Nikolaeva and Bogoslovsky, 2005, C. pseudocompressa Nikolaeva and Bogoslovsky, 2005, Lag. levis Bogoslovsky, 1979, Lam. aktubensis Nikolaeva and Bogoslovsky, 2005, Lam. kiensis Nikolaeva and Bogoslovsky, 2005;

- Karaganda (Kazakhstan): C. medoevi (Bogoslovsky, 1979), C. subcompressa Nikolaeva and Bogoslovsky, 2005;

- Semipalatinsk (Kazakhstan): Pr. tuberculata (Nikolaeva and Bogoslovsky, 2005);

- South China: C. aurita Sun and Shen, 1965, C. chaoi Sun and Shen, 1965, C. spiralia Sun and Shen, 1965, C. parinvolvens Ruan and He, 1974;

- New South Wales (Australia): C. borahensis Pickett, 1960;

The long list demonstrates the diversity and widespread geographic occurrence of the family Cymaclymeniidae. However, many of the species are described from insufficient material, often lacking information about ontogeny or details of shell ornament or suture line. A number of the erected species may be synonyms.

In the course of a revision of the cymaclymeniid ammonoids from Morocco, it became obvious that there is general similarity with species from other regions, but that a detailed investigation with the increase of the number of characters revealed morphological differences. These differences 


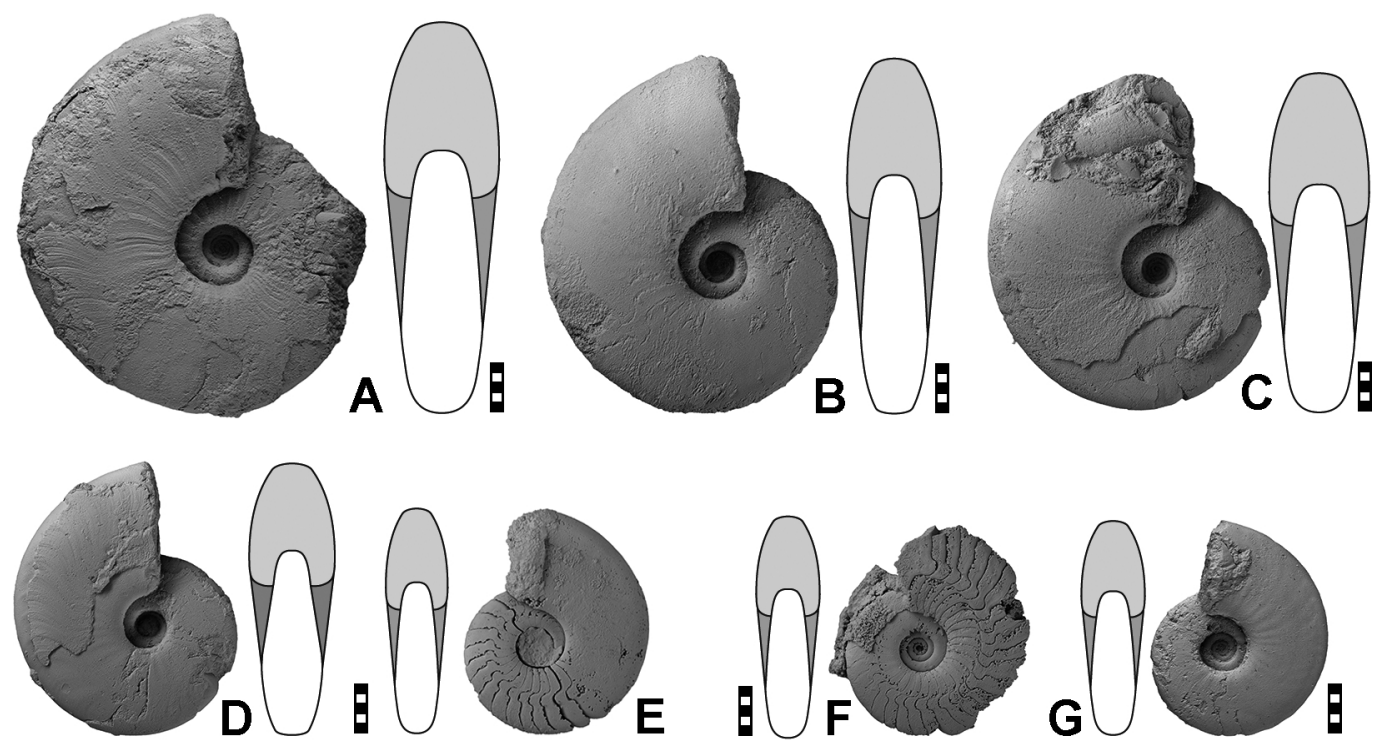

Figure 11. Procymaclymenia ebbighauseni n. sp. from the Anti-Atlas of Morocco; all $\times$ 1.0. (A) Paratype MB.C.22619.1 (Ebbighausen and Korn 2009 Coll.) from Madène el Mrakib. (B) MB.C.22621.1 (Ebbighausen and Korn 2009 Coll.) from Madène el Mrakib. (C) Paratype MB.C.22665.1 (Korn 1995 Coll.) from El Atrous. (D) Paratype MB.C.22665.2 (Korn 1995 Coll.) from El Atrous. (E) Paratype MB.C.22620.2 (Ebbighausen and Korn 2009 Coll.) from Madène el Mrakib. (F) Paratype MB.C.22620.1 (Ebbighausen and Korn 2009 Coll.) from Madène el Mrakib. (G) Paratype MB.C.22622.1 (Ebbighausen and Korn 2009 Coll.) from Madène el Mrakib.

are used here to separate the North African material with the consequence of describing new species.

A total of 1100 specimens of Cymaclymenia and related genera from various localities in the Anti-Atlas of Morocco form the basis for the systematic description below. The entire material is stored in the collection of the Museum für Naturkunde Berlin (MB.C. number prefixes). The description follows the scheme proposed by Korn (2010) for Carboniferous ammonoids.

Order Clymeniida Hyatt, 1884

Suborder Cyrtoclymeniina Korn, 2002

Superfamily Cyrtoclymeniaceae Hyatt, 1884

Family Cymaclymeniidae Hyatt, 1884

\section{Procymaclymenia Korn, 2002}

Type species: Cymaclymenia inflata Czarnocki, 1989, p. 67 (original designation (Korn in Korn and Klug, 2002, p. 220); not " $C y$ maclymenia fundifera Czarnocki, 1989" as erroneously stated on p. 280).

Genus definition: Genus of the Cymaclymeniidae with blunt, slightly asymmetric lateral lobe.

Discussion: Procymaclymenia is a genus that closely resembles Cymaclymenia in conch shape, but differs in the less developed lateral lobe. While this lobe in Cymaclymenia is strongly asymmetric and pointed at the ventral side, it is less asymmetric in Procymaclymenia and does not show the acute ventral side. The genus has thus an intermediate position be- tween Genuclymenia (with widely rounded lateral lobe) and Cymaclymenia (with acute lateral lobe).

The genus has a much more restricted geographic occurrence than Cymaclymenia. Records are so far only known from the Holy Cross Mountains (Czarnocki, 1989), the South Urals (Nikolaeva and Bogoslovsky, 2005) and North Africa.

\section{Procymaclymenia ebbighauseni n. sp.}

Figures 11 and 12

1960 Cymaclymenia striata. - Petter, p. 47, pl. 8, figs. 3, 5, 11, 14. 1999 Cymaclymenia sp. - Korn, p. 170, pl. 4, fig. 6.

2002 Cymaclymenia pudica. - Becker et al., p. 171, pl. 4, figs. 4, 5

Derivation of name: In honour of Volker Ebbighausen (1940-2011), for his contribution to the palaeontology of the Anti-Atlas of Morocco.

Holotype: Specimen MB.C.22621.1 (Ebbighausen and Korn 2009 Coll.); illustrated here in Fig. 11b.

Type locality and horizon: Madène el Mrakib (Anti-Atlas); Procymaclymenia beds (late Famennian).

Material: 252 specimens with a maximum conch diameter of $45 \mathrm{~mm}$.

Diagnosis: Species of Procymaclymenia with thinly discoidal conch in the adult stage $(\mathrm{ww} / \mathrm{dm}=0.28)$; whorl cross section compressed $(\mathrm{ww} / \mathrm{wh}=0.60)$. Conch shape in the intermediate stage $(10 \mathrm{~mm} \mathrm{dm})$ thinly discoidal and subevolute $(\mathrm{ww} / \mathrm{dm}=0.30$ $\mathrm{uw} / \mathrm{dm}=0.32$ ). Umbilical wall steep in the adult stage, flanks subparallel, venter rounded or slightly flattened and separated from the 

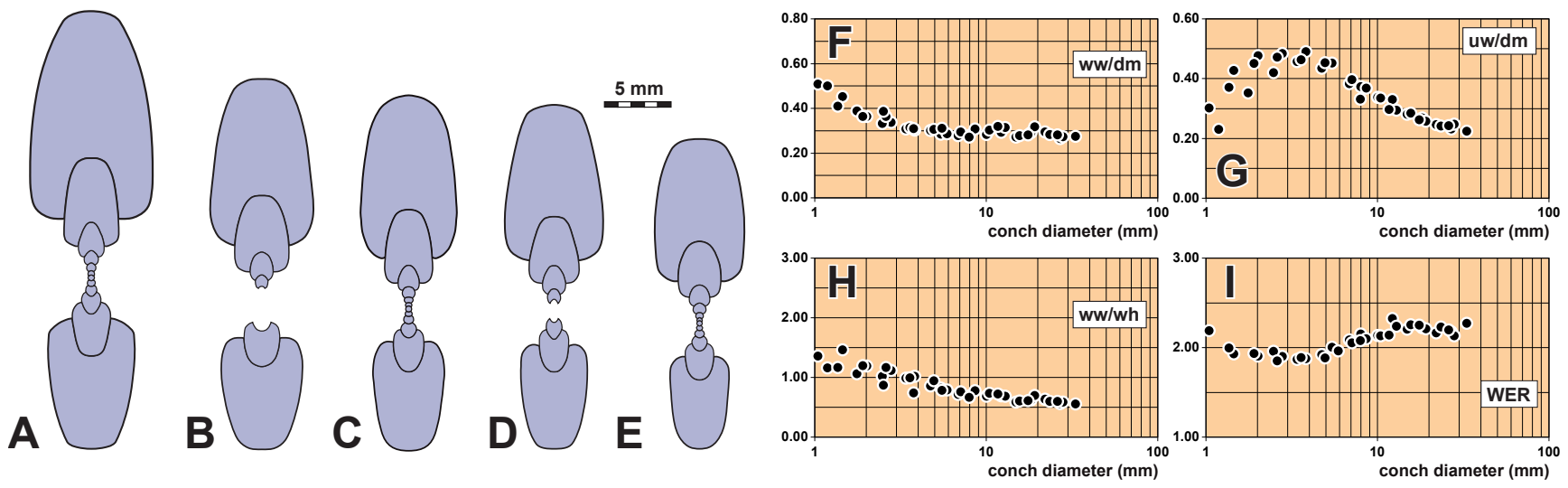

Figure 12. Cross sections $(\mathbf{A}-\mathbf{E}$; all $\times 1.5)$ and ontogenetic trajectories $(\mathbf{F}-\mathbf{I})$ of Procymaclymenia ebbighauseni n. sp. from Madène el Mrakib (Anti-Atlas of Morocco). (A) Paratype MB.C.22619.2 (Ebbighausen and Korn 2009 Coll.). (B) Paratype MB.C.22619.4 (Ebbighausen and Korn 2009 Coll.). (C) Paratype MB.C.22639 (Korn 1998 Coll.). (D) Paratype MB.C.22619.5 (Ebbighausen and Korn 2009 Coll.). (E) Paratype MB.C.22619.3 (Ebbighausen and Korn Coll.). (F) Conch width index (ww/dm). (G) Umbilical width index (ww/wh). (H) Whorl width index (uw / dm). (I) Whorl expansion rate (WER).

Table 2. Conch ontogeny of Procymaclymenia ebbighauseni n. sp. from the Anti-Atlas of Morocco.

\begin{tabular}{llll}
\hline $\mathrm{dm}$ & Conch shape & Whorl cross-section shape & Whorl expansion \\
\hline $2 \mathrm{~mm}$ & thinly discoidal; subevolute & weakly depressed; weakly embracing & moderate \\
& $($ ww $/ \mathrm{dm} \sim 0.38 ;$ uw $/ \mathrm{dm}=0.40-0.45)$ & $($ ww $/$ wh $=1.00-1.25 ;$ IZR $\sim 0.10)$ & $($ WER $\sim 1.90)$ \\
\hline $6 \mathrm{~mm}$ & thinly discoidal; subevolute & weakly compressed; weakly embracing & high \\
& $($ ww $/ \mathrm{dm} \sim 0.30 ;$ uw $/ \mathrm{dm}=0.40-0.45)$ & $($ ww $/$ wh $\sim 0.85 ;$ IZR $\sim 0.20)$ & $($ WER $\sim 2.05)$ \\
\hline \multirow{2}{*}{$15 \mathrm{~mm}$} & thinly discoidal; subinvolute & weakly compressed; weakly embracing & high \\
& $($ ww $/ \mathrm{dm} \sim 0.28 ;$ uw $/ \mathrm{dm} \sim 0.28)$ & $($ ww $/$ wh $\sim 0.62 ;$ IZR $\sim 0.28)$ & $($ WER $\sim 2.20)$ \\
\hline $30 \mathrm{~mm}$ & thinly discoidal; subinvolute & weakly compressed; weakly embracing & high \\
& $($ ww $/ \mathrm{dm} \sim 0.28 ;$ uw $/ \mathrm{dm} \sim 0.24)$ & $($ ww $/$ wh $\sim 0.60 ;$ IZR $=0.25-0.35)$ & $($ WER $\sim 2.20)$ \\
\hline
\end{tabular}

flanks by a subangular margin. Ornament with very fine biconvex growth lines, steinkern without constrictions.

Discussion: Procymaclymenia ebbighauseni differs from $P$. inflata (Czarnocki, 1989) and P. pudica (Czarnocki, 1989) from the Holy Cross Mountains in the smooth steinkern, which in the other two species displays strong constrictions. Furthermore, the other two species possess riblets around the umbilicus, which are very faint in P. ebbighauseni.

The new species was utilised by Becker et al. (2002) as an index for the "Cymaclymenia pudica Zone", which has a position between the "Platyclymenia annulata Zone" and the "Sporadoceras orbiculare Zone". The authors provide a list of co-occurring species, predominantly platyclymeniids and prionoceratids. Recent bed-by-bed research, however, has demonstrated that Procymaclymenia ebbighauseni occurs higher in the section than postulated by Becker et al. (2002); a co-occurrence of typical species of the Platyclymenia annulata Zone and $P$. ebbighauseni does not exist. In the section at Madène el Mrakib, P. ebbighauseni has its lowest occurrences immediately below the oldest horizon with "Sporadoceras orbiculare".

\section{Cymaclymenia Hyatt, 1884}

Type species: Clymenia striata Münster, 1843, p.11 (original designation).

Genus definition: Genus of the Cymaclymeniidae with pointed, strongly asymmetric lateral lobe. Course of the growth-lines biconvex.

Discussion: Cymaclymenia is one of the most species-rich Devonian ammonoid genera; Korn and Klug (2002) listed 40 species within the genus, of which several were regarded as synonymous. A further seven new species were added by Nikolaeva and Bogoslovsky (2005) to Cymaclymenia, but three of these can be regarded as probably belonging to Procymaclymenia, a genus ignored by these authors. This large amount of morphologically similar forms is an obstacle for a clear separation of species, of which only few have been described including the conch ontogeny. Furthermore, 

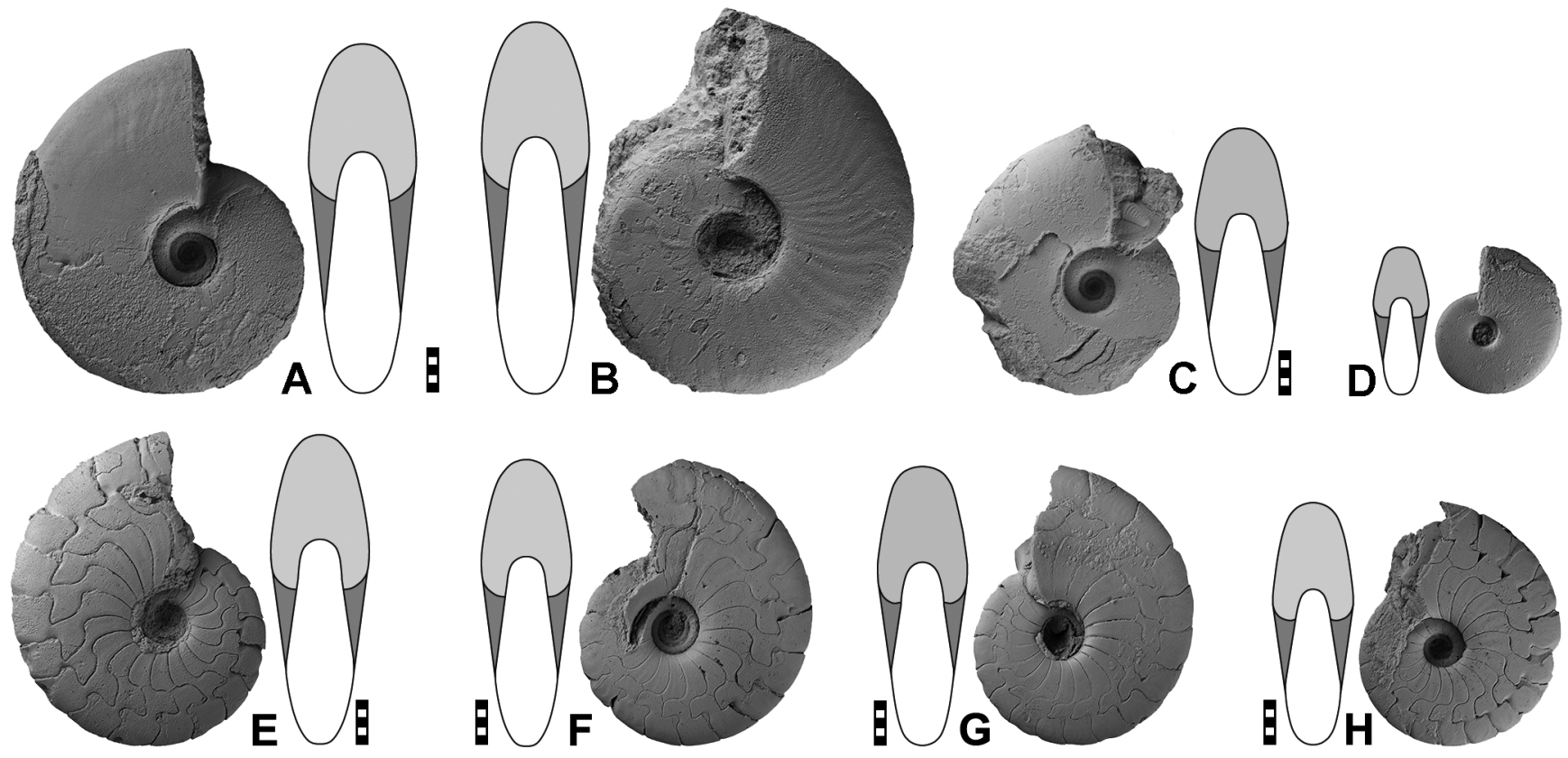

Figure 13. Cymaclymenia subvexa n. sp. from the Anti-Atlas of Morocco; all × 1.0. (A) Holotype MB.C.22658 (Rücklin 2003 Coll.) from Bou Ifarherioun. (B) Paratype MB.C.22636.1 (Korn 1998 Coll.) from Madène el Mrakib. (C) Paratype MB.C.22656.1 (Korn 1993 Coll.) from Bou Tchrafine. (D) Paratype MB.C.22656.2 (Korn 1993 Coll.) from Bou Tchrafine. (E) Paratype MB.C.22691.1 (Ebbighausen 1988 Coll.) from Fezzou. (F) Paratype MB.C.22691.2 (Ebbighausen 1988 Coll.) from Fezzou. (G) Paratype MB.C.22691.3 (Ebbighausen 1988 Coll.) from Fezzou. (H) Paratype MB.C.22689.1 (Ebbighausen 1988 Coll.) from Fezzou.

the precise stratigraphic occurrence is not known for many species for which, if at all, only the stage is known.

The material of Cymaclymenia from Morocco and Algeria has traditionally (e.g. Petter, 1960; Korn, 1999; Becker et al., 2002) been assigned to species previously described from central Europe (e.g. Franconia, Rhenish Mountains). In fact there is some resemblance, but at the same time there are differences when well-preserved material is studied and compared. Generally it appears that the material from the AntiAtlas has a weaker shell ornament when compared with the European species, while differences in conch geometry and suture lines are only minor. The differences in shell ornament are used here as a criterion for the separation of new species within the genus, giving the cymaclymeniid faunas from North Africa an exotic character containing endemic species.

A concept of largely endemic faunas has been used by Nikolaeva and Bogoslovsky (2005), who besides using names from central European species, named four new species from the South Urals and central Kazakhstan.

\section{Cymaclymenia subvexa $\mathbf{n}$. sp.}

Figures 13 and 14

1960 Cymaclymenia striata. - Petter, p. 47, pl. 7, figs. 16, 17, 19, pl. 8, figs. 1, 4, 13.

1999 Cymaclymenia cordata. - Korn, p. 170, pl. 4, fig. 5.
Derivation of name: After Lat. subvexus, - a, -um (adj.) = oblique, because of the shape of the umbilical wall.

Holotype: Specimen MB.C.22658 (Rücklin 2003 Coll.); illustrated here in Fig. 13a.

Type locality and horizon: Bou Ifarherioun $17 \mathrm{~km}$ south of Rissani; Gonioclymenia Assemblage (late Famennian).

Material: 383 specimens with a maximum conch diameter of $50 \mathrm{~mm}$.

Diagnosis: Species of Cymaclymenia with thinly discoidal conch in the adult stage ( $\mathrm{ww} / \mathrm{dm}=0.30-0.35$ ); whorl cross section weakly compressed $(\mathrm{ww} / \mathrm{wh}=0.65)$. Conch shape in the intermediate stage $(10 \mathrm{~mm} \mathrm{dm})$ thinly discoidal and subevolute $(\mathrm{ww} / \mathrm{dm}=0.32$; $\mathrm{uw} / \mathrm{dm}=0.32$ ). Umbilical wall oblique in the adult stage, flanks moderately converging, venter narrowly rounded. Ornament with very fine biconvex growth lines and with weak riblets on the flank.

Discussion: Cymaclymenia subvexa is one of the slender species of the genus. It differs from many of the other species in the presence of riblets on the inner flanks. Of the Uralian species, C. decorata Nikolaeva and Bogoslovsky, 2005 has even stronger and sharper riblets and $C$. crenata Nikolaeva and Bogoslovsky, 2005 has a rather blunt lateral lobe as well as a stronger biconvex course of the growth lines. $C$. silesiaca (Renz, 1914) from Silesia possesses steinkern constrictions at the end of growth. 


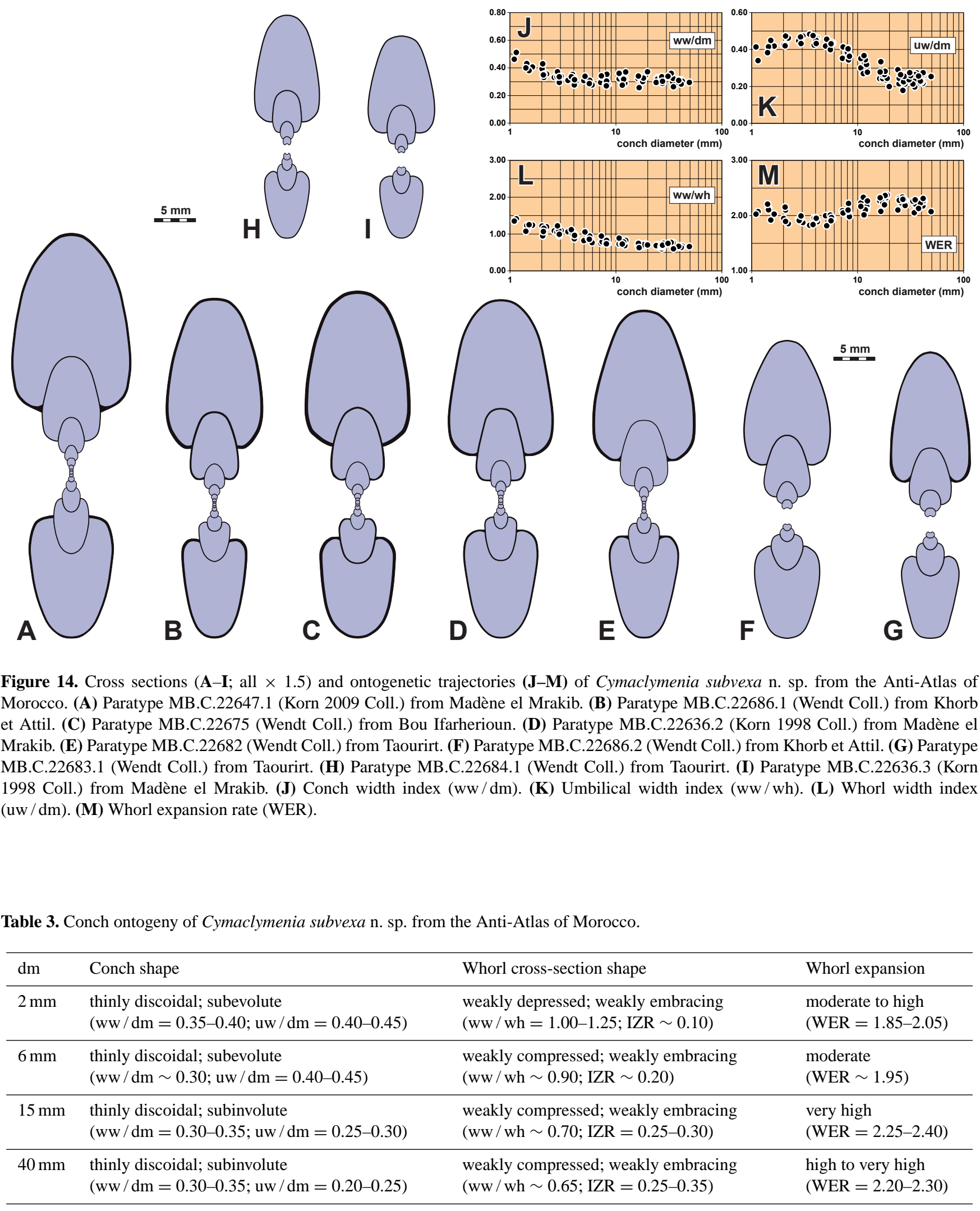



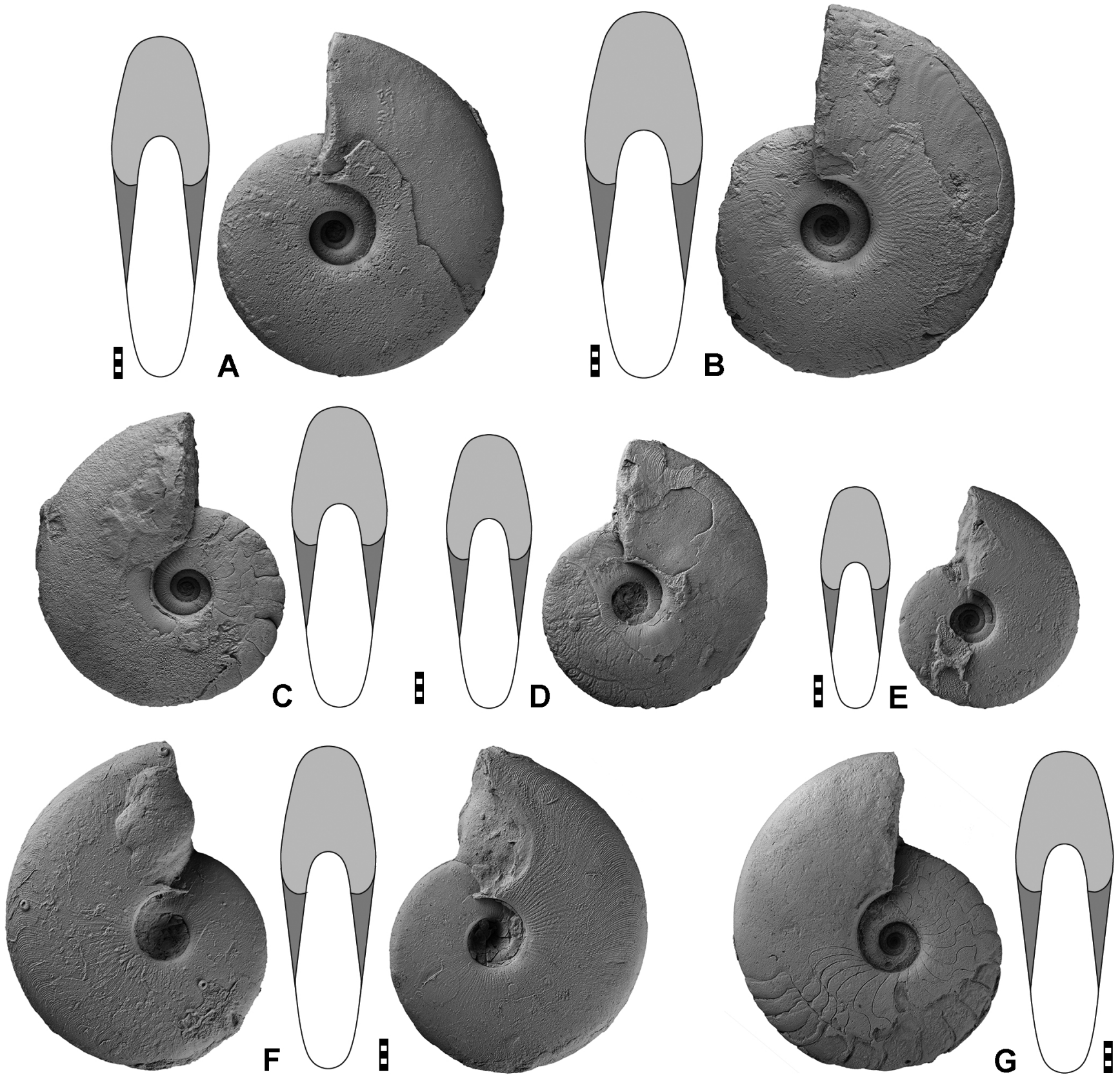

Figure 15. Cymaclymenia formosa n. sp. from the Anti-Atlas of Morocco; all × 1.0. (A) Holotype MB.C.22609.1 (Korn 1995 Coll.) from Erfoud. (B) Paratype MB.C.22669.1 (Wendt Coll.) from Hamar Laghdad. (C) Paratype MB.C.22669.2 (Wendt Coll.) from Hamar Laghdad. (D) Paratype MB.C.22669.3 (Wendt Coll.) from Hamar Laghdad. (E) Paratype MB.C.22649.1 (Korn 2009 Coll.) from Lambidia (Aguelmous). (F) Paratype MB.C.22649.2 (Korn 2009 Coll.) from Lambidia (Aguelmous). (G) Paratype MB.C.22669.4 (Wendt Coll.) from Hamar Laghdad.

The new species resembles Procymaclymenia ebbighauseni and Cymaclymenia formosa in conch geometry and ontogeny. P. ebbighauseni is easily separable by the suture line (blunt in $P$. ebbighauseni, pointed in C. subvexa), but the differences with $C$. formosa are less obvious. The two species can best be separated by the form of the umbilical wall, which is oblique in $C$. subvexa (with an inclination of about $45^{\circ}$ ) but steep in C. formosa. $C$. serotina lacks the flank riblets of $C$. subvexa. 
Table 4. Conch ontogeny of Cymaclymenia formosa n. sp. from the Anti-Atlas of Morocco.

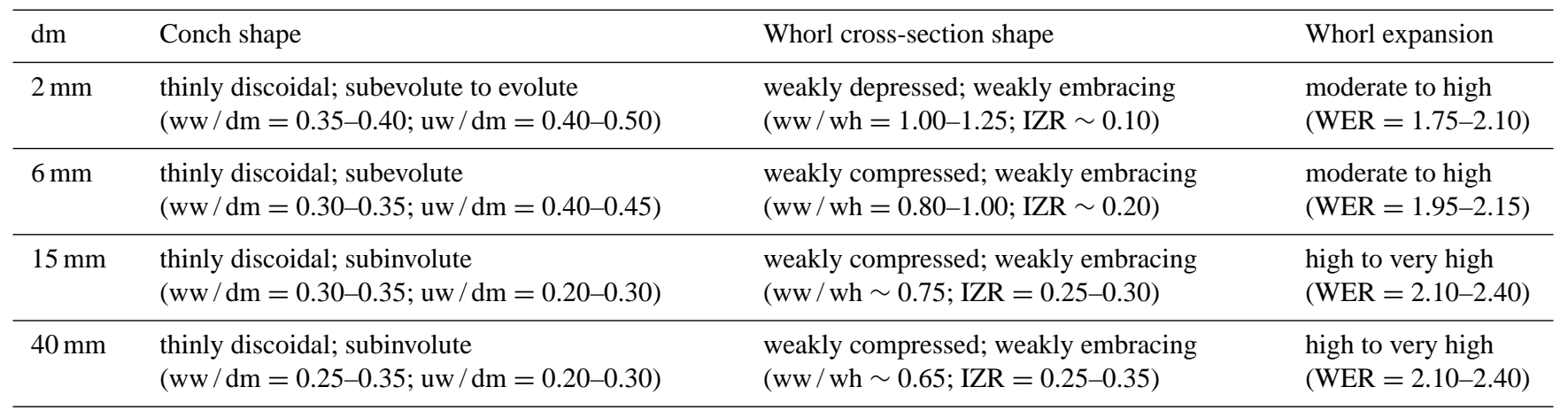

Cymaclymenia formosa $\mathbf{n}$. sp.

Figures 15 and 16

1999 Cymaclymenia striata. - Korn, p. 170, pl. 4, fig. 1.

1999 Cymaclymenia costellata. - Korn, p. 170, pl. 4, fig. 2.

2002 Cymaclymenia involvens. - Becker et al., p. 165.

Derivation of name: After Lat. formosus, - $a$, -um (adj.) = pretty; because of the delicate ornament of the species.

Holotype: Specimen MB.C.22609.1 (Korn 1995 Coll.); illustrated here in Fig. 15a.

Type locality and horizon: Erfoud (Anti-Atlas), immediately east of the Muslim cemetery on the eastern side of the Ziz Valley; bed 4950 of Korn (1999), Parawocklumeria paradoxa Assemblage (late Famennian).

Material: 267 specimens with a maximum conch diameter of $60 \mathrm{~mm}$.

Diagnosis: Species of Cymaclymenia with thinly discoidal conch in the adult stage ( $\mathrm{ww} / \mathrm{dm}=0.30-0.35$ ); whorl cross section weakly compressed $(\mathrm{ww} / \mathrm{wh}=0.65)$. Conch shape in the intermediate stage $(10 \mathrm{~mm} \mathrm{dm})$ thinly discoidal and subevolute $(\mathrm{ww} / \mathrm{dm}=0.35$; $\mathrm{uw} / \mathrm{dm}=0.30-0.35)$. Umbilical wall steep in the adult stage, flanks weakly converging, venter rounded. Ornament with fine biconvex growth lines, without riblets.

Discussion: The new species closely resembles $C$. striata (Münster, 1832), which has a similar conch geometry and ornament. C. semistriata Münster (1832) is another similar and possibly separate species; it shows strong constrictions on the internal mould, which appear to be absent in $C$. striata. C. striata is characterised by very coarse, lamellose growth lines, which are arranged in equal distances of about $0.5 \mathrm{~mm}$ on the outer flanks (topotype specimen MB.C.4173 from Schübelhammer) (Fig. 17). In contrast the growth lines are much finer in C. formosa and stand in distances of about $0.25 \mathrm{~mm}$. The steinkern constrictions, characteristic of $C$. semistriata, are absent in C. formosa.

Another similar species is $C$. costellata (Münster, 1832) (Fig. 18), but this species possesses riblets on the inner flanks. More differences can be seen in the ontogeny of the conch, $C$. formosa shows a clear triphasic ontogeny of the $\mathrm{ww} / \mathrm{dm}$ ratio with a very slender juvenile stage $(\mathrm{ww} / \mathrm{dm}=$ $0.30-0.35$ at $6 \mathrm{~mm} \mathrm{dm})$. The inner whorls are stouter in $C$. costellata $(\mathrm{ww} / \mathrm{dm}=0.40-0.45$ at $6 \mathrm{~mm} \mathrm{dm}$ ) (Fig. 19). Furthermore, $C$. costellata shows adult modifications such as a slightly tabulated venter and a deep terminal steinkern constriction.

C. formosa differs from C. subvexa from the Anti-Atlas in the nearly parallel flanks in the adult stage, which in $C$. subvexa converge more strongly towards the narrow venter. Furthermore $C$. subvexa has a more slender juvenile conch at $4 \mathrm{~mm}$ diameter ( $\mathrm{ww} / \mathrm{dm} \sim 0.34$ in $C$. formosa but $\sim 0.30$ in $C$. subvexa). The best criterion for the separation of the species is the form of the umbilical wall, which in C. formosa is steep, but oblique in $C$. subvexa (about $45^{\circ}$ ). C. serotina differs from $C$. formosa in the almost smooth shell surface.

C. subcompressa Nikolaeva and Bogoslovsky, 2005 and $C$. pseudocompressa Nikolaeva and Bogoslovsky, 2005 have a similar shape, but the first species has an almost smooth shell and the second has lamellar growth lines, much coarser than in C. formosa.

\section{Cymaclymenia lambidia $\mathbf{n}$. sp.}

Figures 20 and 21

1960 Cymaclymenia involvens. - Petter, p. 47, pl. 7, fig. 20, 21, 23, pl. 8, fig. 6, 8-10.

1999 Cymaclymenia involvens. - Korn, p. 170, pl. 4, fig. 3, 4.

2002 Cymaclymenia involvens. - Becker et al., p. 165, 173.

Derivation of name: After the geographic region Lambidia in the Ma'der Basin.

Holotype: Specimen MB.C.22632.1 (Korn 1998 Coll.); illustrated here in Fig. 20a.

Type locality and horizon: Madène el Mrakib; $0-5 \mathrm{~m}$ below Hangenberg Black Shale, probably Parawocklumeria paradoxa Assemblage (late Famennian).

Material: 128 specimens with a maximum conch diameter of $65 \mathrm{~mm}$. 

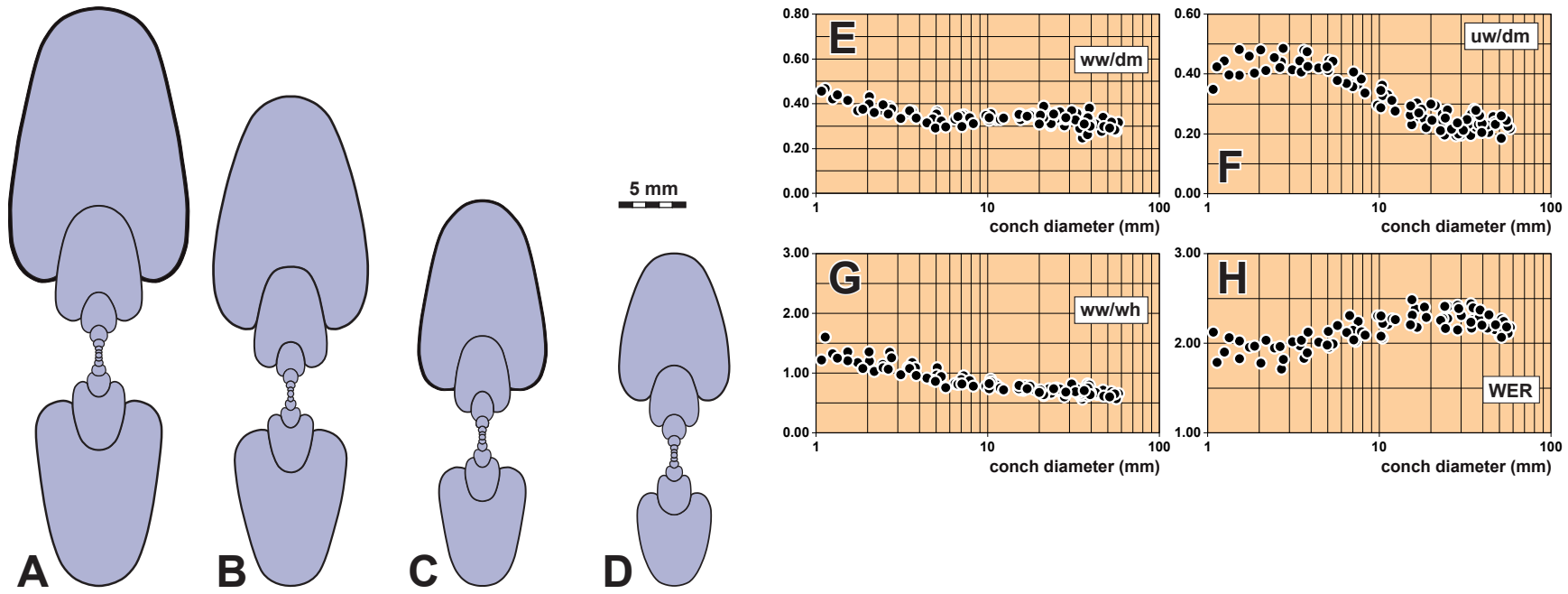

Figure 16. Cross sections $(\mathbf{A}-\mathbf{D}$; all $\times 1.5)$ and ontogenetic trajectories $(\mathbf{E}-\mathbf{H})$ of Cymaclymenia formosa $\mathrm{n}$. sp. from the Anti-Atlas of Morocco. (A) Paratype MB.C.22649.3 (Korn 2009 Coll.) from Lambidia. (B) Paratype MB.C.22646.1 (Korn 2009 Coll.) from Madène el Mrakib. (C) Paratype MB.C.22646.2 (Korn 2009 Coll.) from Madène el Mrakib. (D) Paratype MB.C.22646.3 (Korn 2009 Coll.) from Madène el Mrakib. (E) Conch width index (ww/dm). (F) Umbilical width index (ww/wh). (G) Whorl width index (uw/dm). (H) Whorl expansion rate (WER).
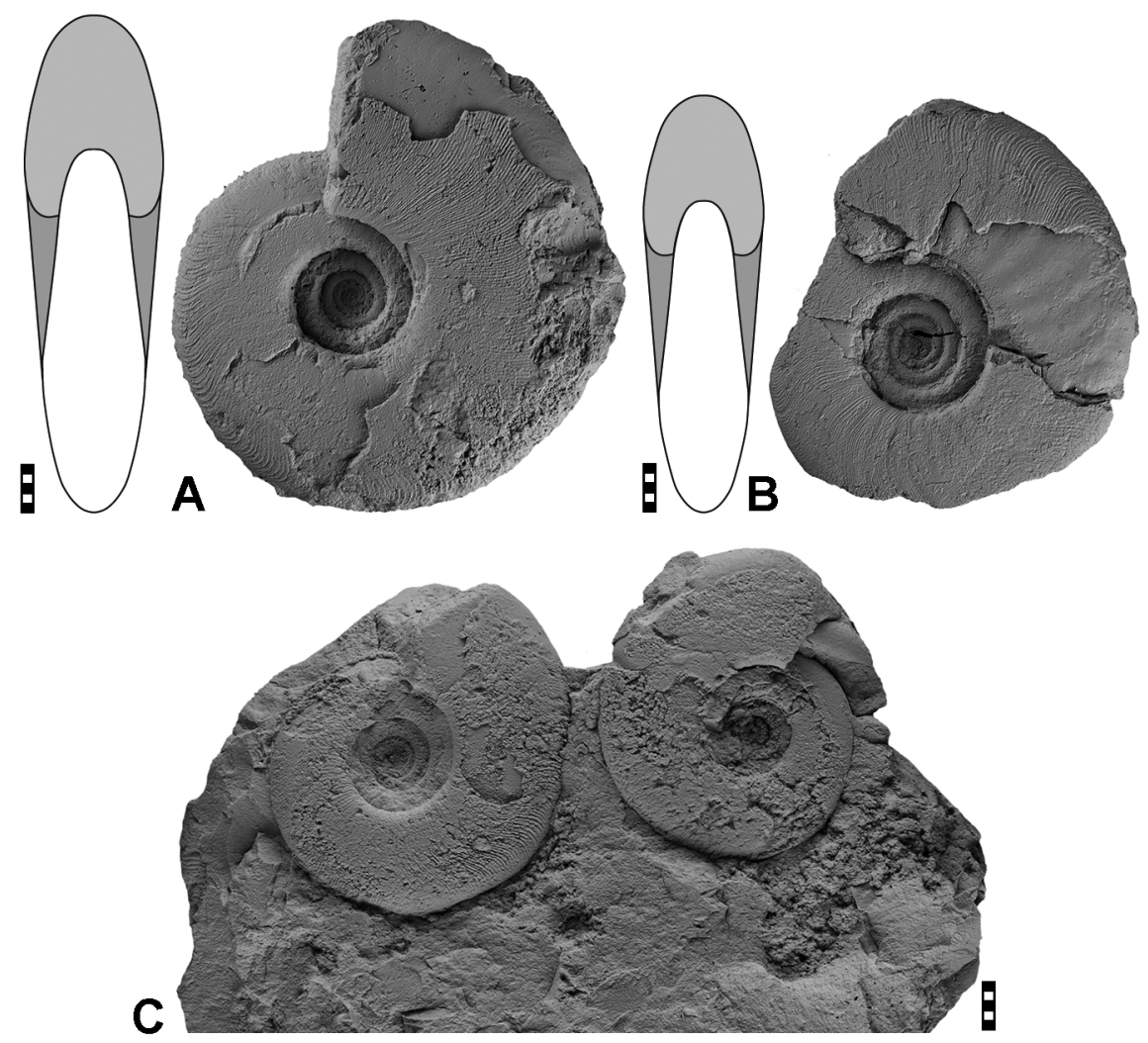

Figure 17. Topotypes of Cymaclymenia striata (Münster, 1832) from Schübelhammer (Upper Franconia, Germany); all × 1.0. (A) Specimen MB.C.4184 (Münster Coll.). (B) Specimen MB.C.4195 (Münster Coll.). (C) Specimen MB.C.4173 (Münster Coll.). 

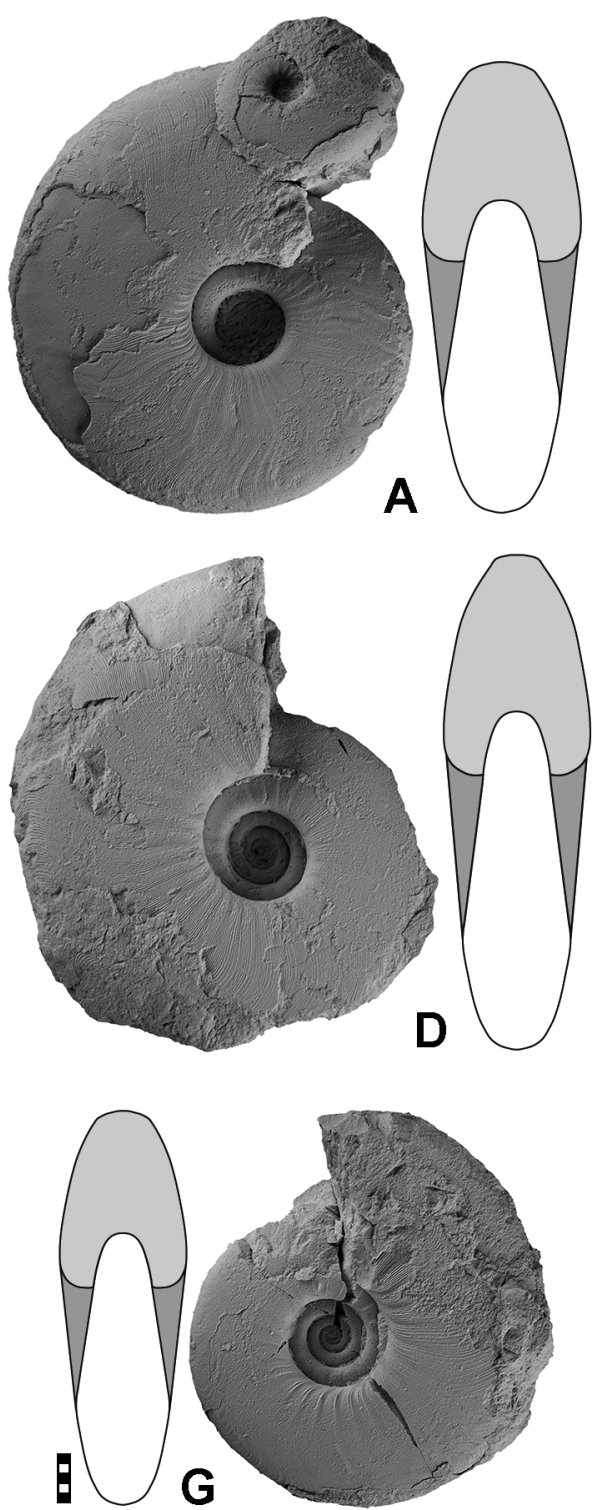
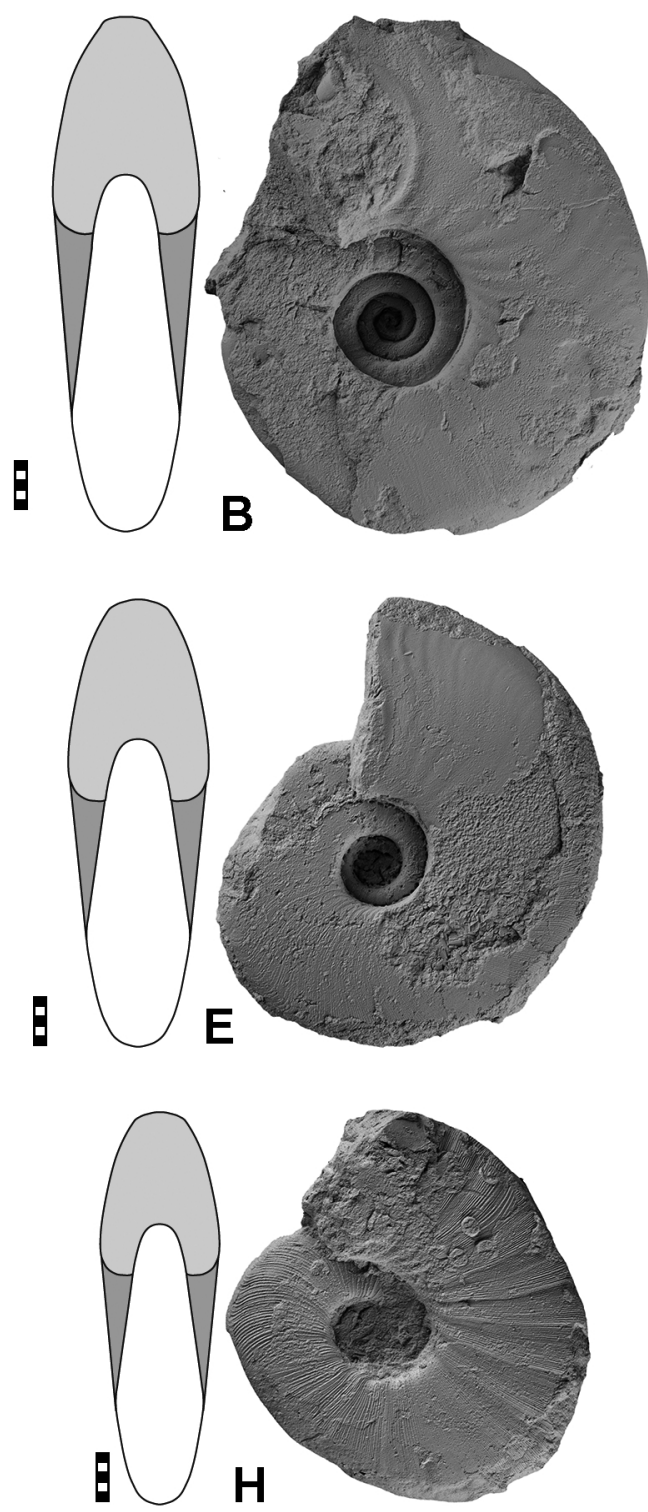
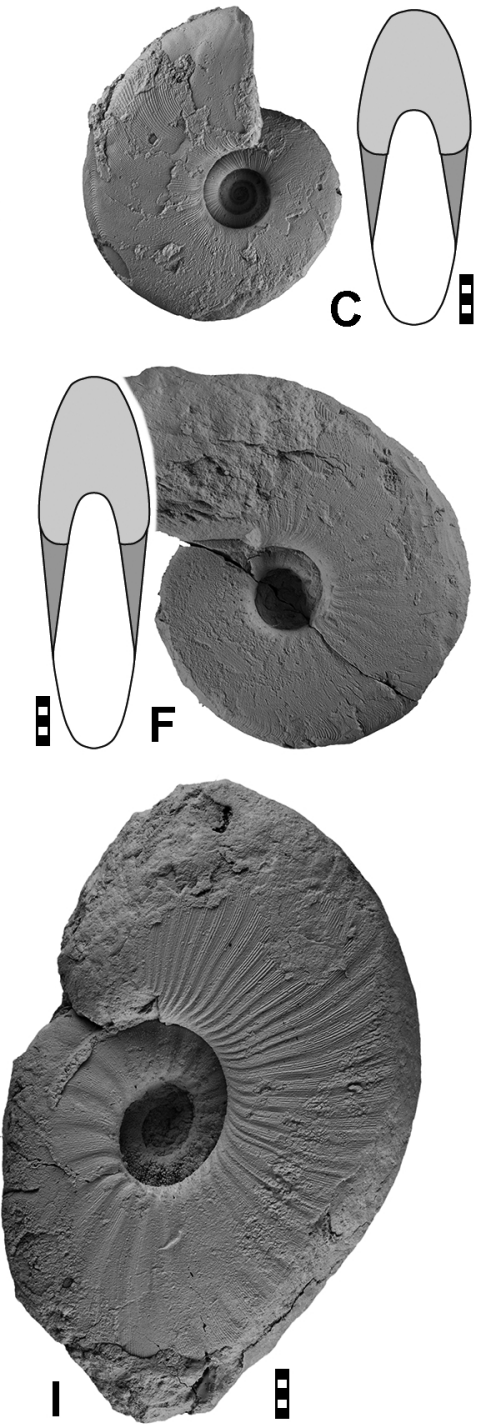

Figure 18. Cymaclymenia costellata (Münster, 1832) from the Rhenish Mountains (Germany); all × 1.0. (A) Specimen MB.C.22692 (Korn 1974 Coll.) from Reigern. (B) Specimen MB.C.4179 (Denckmann 1900 Coll.) from Wettmarsen. (C) Specimen MB.C.22695.1 (Korn 1977 Coll.) from Oberrödinghausen. (D) Specimen MB.C.22700 (Schindewolf 1931 Coll.) from Hauern near Braunau. (E) Specimen MB.C.22697 (Korn 1987 Coll.) from Effenberg. (F) Specimen MB.C.4185 (Lotz and Denckmann 1900 Coll.) from Langenholthausen. (G) Specimen MB.C.22701 (Denckmann 1895 Coll.) from Hauern. (H) Specimen MB.C.4202.2 (purchased 1903) from Hauern. (I) Specimen MB.C.4202.1 (purchased 1903) from Hauern.

Diagnosis: Species of Cymaclymenia with thinly discoidal conch in the adult stage ( $\mathrm{ww} / \mathrm{dm}=0.35-0.40$ ); whorl cross section weakly compressed ( $w w / w h=0.80-1.00)$. Conch shape in the intermediate stage $(10 \mathrm{~mm} \mathrm{dm})$ thickly discoidal and subevolute $(\mathrm{ww} / \mathrm{dm}=$ $0.50 ; \mathrm{uw} / \mathrm{dm}=0.30-0.35$ ). Umbilical wall steep in the adult stage, flanks moderately converging, venter broadly rounded. Ornament with fine biconvex growth lines, without riblets.

Discussion: Cymaclymenia lambidia belongs to the stouter species of the genus and is by this character separated from most of the other species such as the co-occurring $C$. lam- bidia. Only few of the described species reach the adult $\mathrm{ww} / \mathrm{dm}$ ratio of 0.35 .

Specimens belonging to this new species have usually been assigned to Cymaclymenia involvens Lange, 1929. Indeed this species is very similar in conch shape (Fig. 22), and differences are mainly expressed in shell ornament. Two specimens from Wocklum are available from the type material of $C$. involvens: (1) the smaller holotype MB.C.3695 (27 mm dm), which is fairly well preserved with a rather coarse shell ornament, and (2) the larger paratype 

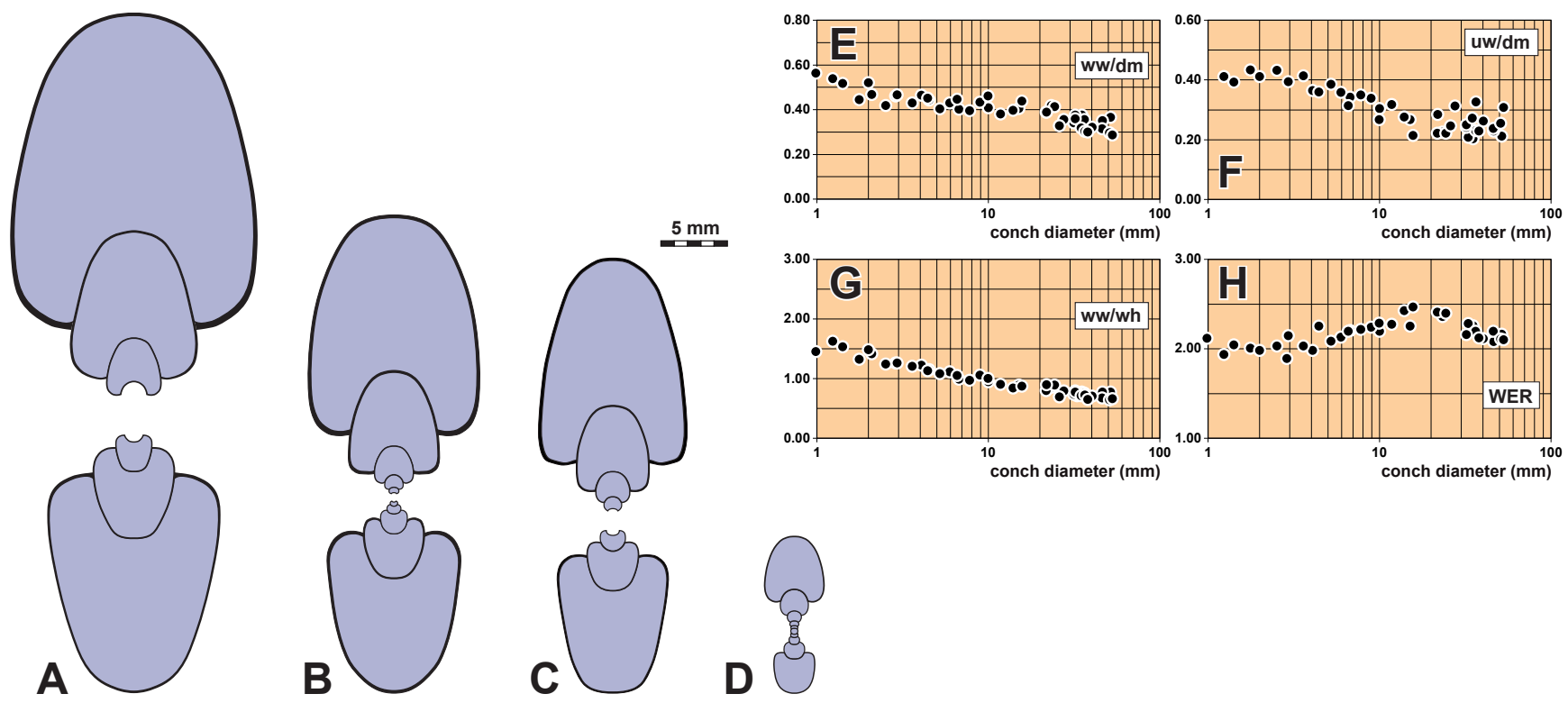

Figure 19. Cross sections $(\mathbf{A}-\mathbf{D}$; all $\times 1.5)$ and ontogenetic trajectories $(\mathbf{E}-\mathbf{H})$ of Cymaclymenia costellata $($ Münster, 1832) from the Rhenish Mountains of Germany. (A) Specimen MB.C.22693 (Korn 1975 Coll.) from Reigern. (B) Specimen MB.C.22694 (Korn 1974 Coll.) from Reigern. (C) Specimen MB.C.22695.2 (Korn 1977 Coll.) from Oberrödinghausen. (D) Specimen MB.C.22695.3 (Korn 1977 Coll.) from Oberrödinghausen. (E) Conch width index (ww/dm). (F) Umbilical width index (ww/wh). (G) Whorl width index (uw/dm). (H) Whorl expansion rate (WER).
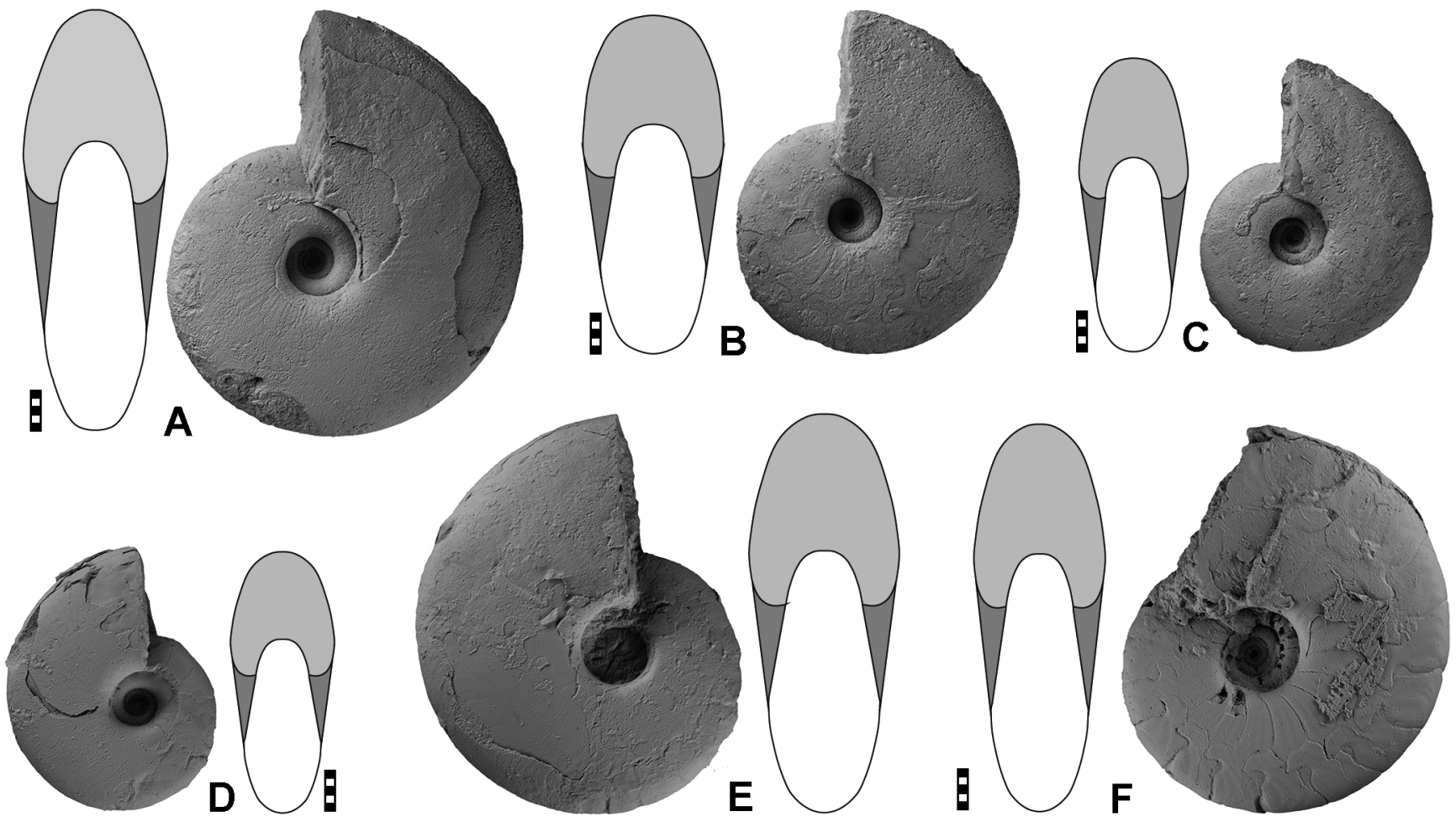

Figure 20. Cymaclymenia lambidia n. sp. from the Anti-Atlas of Morocco; all × 1.0. (A) Holotype MB.C.22632.1 (Korn 1998 Coll.) from Madène el Mrakib. (B) Paratype MB.C.22632.2 (Korn 1998 Coll.) from Madène el Mrakib. (C) Paratype MB.C.22604.1 (Korn 1995 Coll.) from Erfoud. (D) Paratype MB.C.22604.2 (Korn 1995 Coll.) from Erfoud. (E) Paratype MB.C.22604.3 (Korn 1995 Coll.) from Erfoud. (F) Paratype MB.C.22677 (Wendt Coll.) from Aguelmous. 

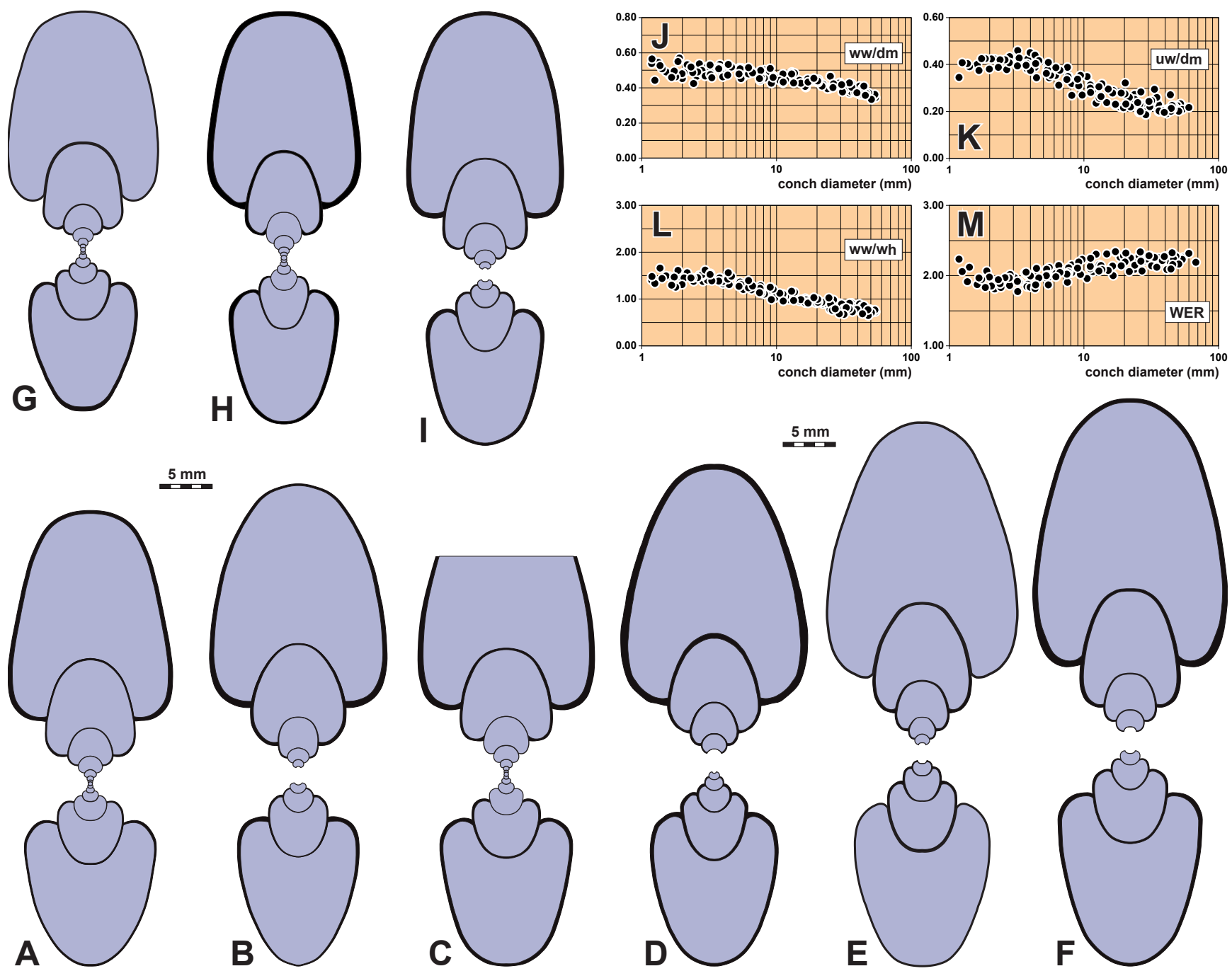

Figure 21. Cross sections $(\mathbf{A}-\mathbf{I}$; all $\times 1.5)$ and ontogenetic trajectories $(\mathbf{J}-\mathbf{M})$ of Cymaclymenia lambidia $\mathrm{n}$. sp. from the Anti-Atlas of Morocco. (A) Paratype MB.C.22632.3 (Korn 1998 Coll.) from Madène el Mrakib. (B) Paratype MB.C.22652.1 (Kullmann Coll.) from Aguelmous. (C) Paratype MB.C.22648.1 (Korn 2009 Coll.) from Lambidia (Aguelmous). (D) Paratype MB.C.22652.2 (Kullmann Coll.) from Aguelmous. (E) Paratype MB.C.22652.3 (Kullmann Coll.) from Aguelmous. (F) Paratype MB.C.22652.4 (Kullmann Coll.) from Aguelmous. (G) Paratype MB.C.22652.5 (Kullmann Coll.) from Aguelmous. (H) Paratype MB.C.22667.1 (Wendt Coll.) from Tizi Ibaouane. (I) Paratype MB.C.22626.1 (Feist 1990 Coll.) from Madène el Mrakib. (J) Conch width index (ww / dm). (K) Umbilical width index (ww / wh). (L) Whorl width index (uw / dm). (M) Whorl expansion rate (WER).

Table 5. Conch ontogeny of Cymaclymenia lambidia n. sp. from the Anti-Atlas of Morocco.

\begin{tabular}{llll}
\hline $\mathrm{dm}$ & Conch shape & Whorl cross-section shape & Whorl expansion \\
\hline $2 \mathrm{~mm}$ & $\begin{array}{l}\text { thickly discoidal; subevolute } \\
(\text { ww } / \mathrm{dm}=0.45-0.60 ; \mathrm{uw} / \mathrm{dm}=0.38-0.42)\end{array}$ & $\begin{array}{l}\text { weakly depressed; weakly embracing } \\
(\text { ww } / \text { wh }=1.30-1.50 ; \text { IZR } \sim 0.10)\end{array}$ & $\begin{array}{l}\text { moderate } \\
(\text { WER }=1.80-2.00)\end{array}$ \\
\hline \multirow{2}{*}{$6 \mathrm{~mm}$} & $\begin{array}{l}\text { thickly discoidal; subevolute } \\
(\text { ww } / \mathrm{dm}=0.45-0.55 ; \mathrm{uw} / \mathrm{dm}=0.35-0.40)\end{array}$ & $\begin{array}{l}\text { weakly depressed; weakly embracing } \\
(\text { ww } / \text { wh }=1.20-1.30 ; \text { IZR }=0.20-0.25)\end{array}$ & $\begin{array}{l}\text { high } \\
(\text { WER }=2.00-2.15)\end{array}$ \\
\hline \multirow{2}{*}{$15 \mathrm{~mm}$} & thinly discoidal; subinvolute & weakly depressed; weakly embracing & high to very high \\
& $($ ww $/ \mathrm{dm}=0.40-0.45 ; \mathrm{uw} / \mathrm{dm}=0.20-0.30)$ & $($ ww $/$ wh $=1.00-1.10 ;$ IZR $=0.25-0.30)$ & $($ WER $=2.10-2.30)$ \\
\hline \multirow{2}{*}{$40 \mathrm{~mm}$} & thinly discoidal; subinvolute & weakly compressed; weakly embracing & high to very high \\
& $($ ww $/ \mathrm{dm}=0.35-0.40 ; \mathrm{uw} / \mathrm{dm}=0.20-0.25)$ & $($ ww $/$ wh $=0.80-1.00 ;$ IZR $=0.25-0.35)$ & $($ WER $=2.10-2.30)$ \\
\hline
\end{tabular}



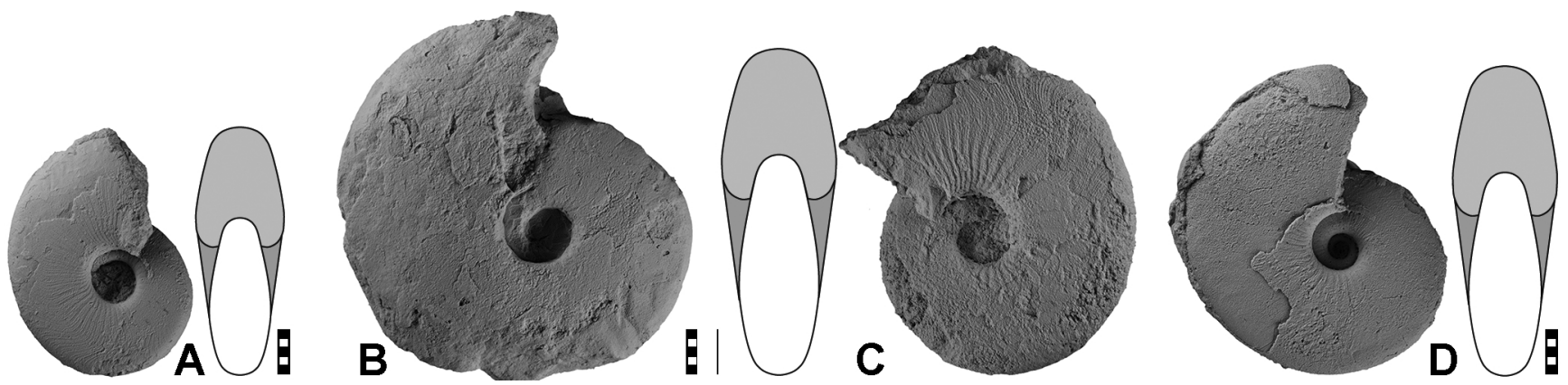

Figure 22. Cymaclymenia involvens Lange, 1929 from the Rhenish Mountains (Germany); all × 1.0. (A) Holotype MB.C.3695 (Lange 1923 Coll.) from Wocklum. (B) Paratype MB.C.3696 (Lange 1923 Coll.) from Wocklum. (C) Specimen MB.C.22698 (Korn 1975 Coll.) from Dasberg. (D) Specimen MB.C.22699 (Korn 1990 Coll.) from Dasberg.

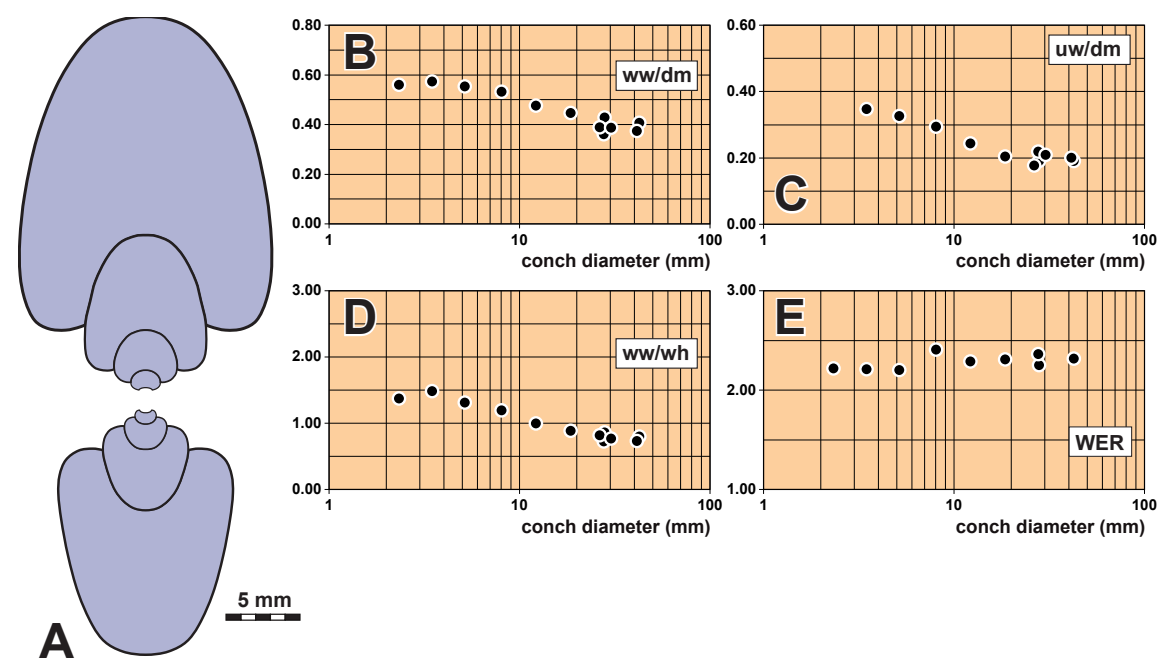

Figure 23. Cross section $(\mathbf{A} ; \times 1.5)$ and ontogenetic trajectories $(\mathbf{B}-\mathbf{E})$ of Cymaclymenia involvens Lange, 1929 from the Rhenish Mountains of Germany. (A) Specimen MB.C.22696 (Korn 1977 Coll.) from Becke-Oese. (B) Conch width index (ww / dm). (C) Umbilical width index (ww/wh). (D) Whorl width index (uw / dm). (E) Whorl expansion rate (WER).

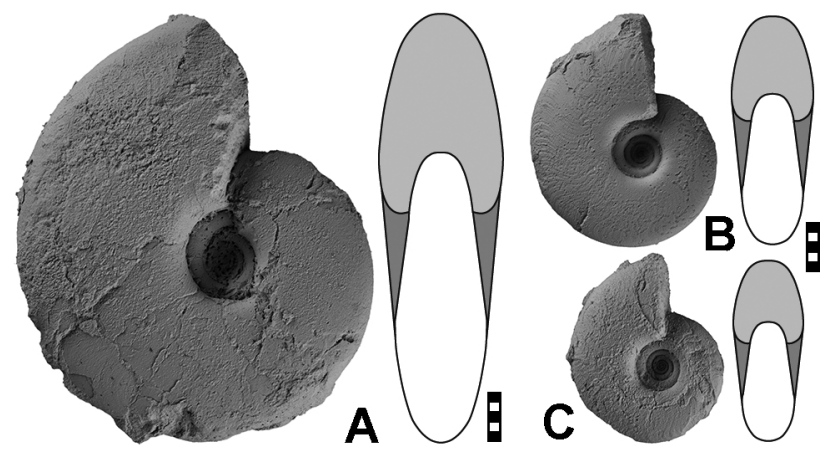

Figure 24. Cymaclymenia serotina $\mathrm{n}$. sp. from the Anti-Atlas of Morocco; all × 1.0. (A) Holotype MB.C.22605.1 (Korn 1995 Coll.) from Erfoud. (B) Paratype MB.C.22605.2 (Korn 1995 Coll.) from Erfoud. (C) Paratype MB.C.22605.3 (Korn 1995 Coll.) from Erfoud.
MB.C.3695 (42 mm dm), which is a poorly preserved, rather strongly corroded internal mould providing insight into the adult conch morphology. It is not certain that the two specimens belong to only one species. However the stratigraphic restriction of the type locality, in which almost exclusively the topmost Wocklum Limestone (Wocklumeria denckmanni Zone) yields ammonoids, suggests that the material is conspecific. The most probable stratigraphic position of the topotypes allows for the designation of time-equivalent specimens for a more precise characterisation of the species.

$C$. involvens differs from the other central European species of the genus in the stouter conch, which only in $C$. nephroides Korn, 1981 is even wider. Like the other two very common species C. striata (Münster, 1832) and C. costellata (Münster, 1832), it possesses a rather coarse shell ornament with bundled growth lines and weak riblets around the umbilicus. 


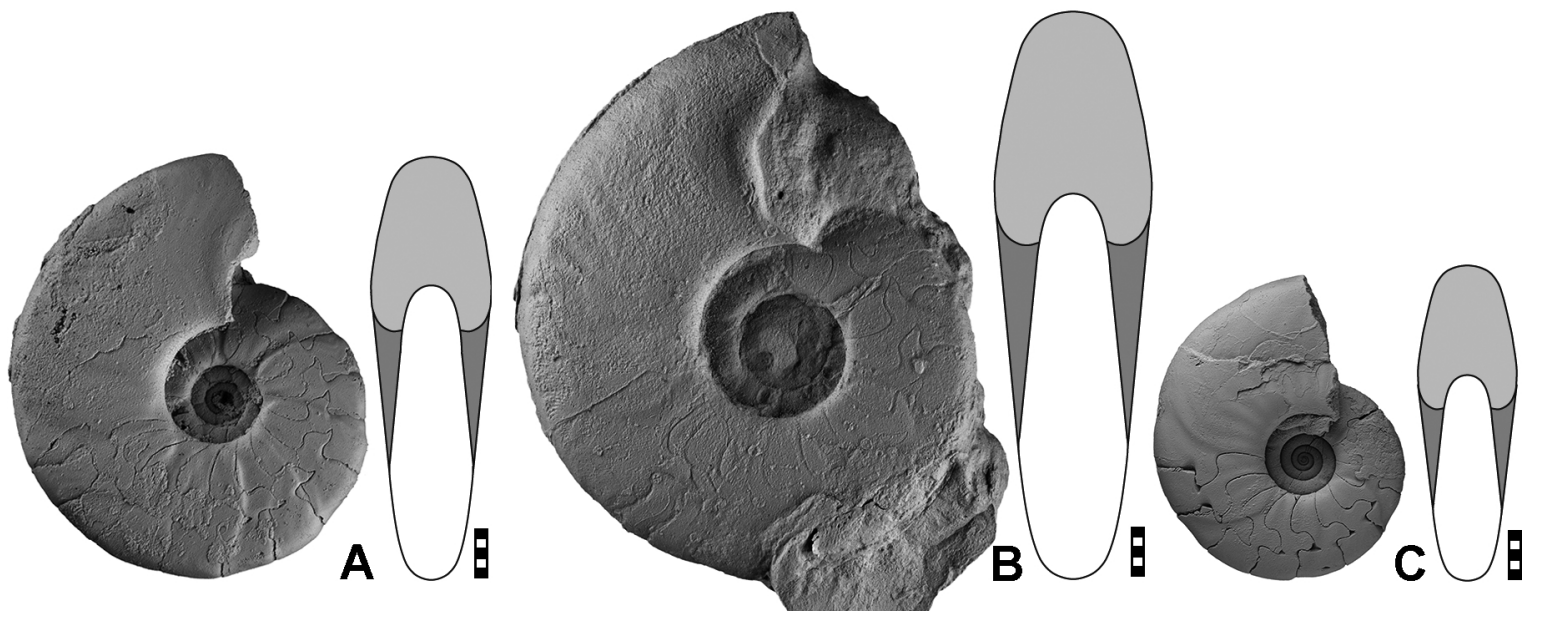

Figure 25. Cymaclymenia aulax n. sp. from the Anti-Atlas of Morocco; all × 1.0. (A) Holotype MB.C.22651 (Ebbighausen 2008 Coll.) from Aguelmous. (B) Paratype MB.C.22650 (Ebbighausen 2003 Coll.) from Lambidia (Aguelmous). (C) Paratype MB.C.22690 (Ebbighausen Coll.) from Fezzou.

Table 6. Conch ontogeny of Cymaclymenia serotina n. sp. from the Anti-Atlas of Morocco.

\begin{tabular}{llll}
\hline $\mathrm{dm}$ & Conch shape & Whorl cross-section shape & Whorl expansion \\
\hline \multirow{2}{*}{$15 \mathrm{~mm}$} & thinly discoidal; subinvolute & weakly compressed; weakly embracing & very high \\
& $(\mathrm{ww} / \mathrm{dm} \sim 0.33 ; \mathrm{uw} / \mathrm{dm} \sim 0.28)$ & $($ ww $/$ wh $\sim 0.80 ;$ IZR $\sim 0.20)$ & (WER $\sim 2.40)$ \\
\hline \multirow{2}{*}{$40 \mathrm{~mm}$} & thinly discoidal; subinvolute & weakly compressed; weakly embracing & very high \\
& $(\mathrm{ww} / \mathrm{dm} \sim 0.30 ; \mathrm{uw} / \mathrm{dm} \sim 0.20)$ & $($ ww $/$ wh $\sim 0.63 ;$ IZR $\sim 0.25)$ & $($ WER $\sim 2.40)$ \\
\hline
\end{tabular}

C. lambidia differs from the European and Uralian species in the much weaker ornament, which particularly in subadult specimens (about $20 \mathrm{~mm}$ conch diameter) appears to be absent and thus suggesting a smooth shell surface. Another difference of the new species from $C$. involvens is the slightly stouter conch in the juvenile stage of $8 \mathrm{~mm}$ conch diameter (ww $/ \mathrm{dm}=0.45-0.50$ in C. lambidia; $\mathrm{ww} / \mathrm{dm}=0.53$ in $C$. involvens) (Fig. 23). This criterion, however, probably does not allow for a clear separation of the two species.

Becker et al. (2002, p. 165, 173) introduced a " $C y$ maclymenia involvens Zone" for specimens of this species. This zone should occur between two sandstone members near the top of the Late Devonian succession at Lambidia (Aguelmous, Ma'der Basin); the zone was placed above the "Hangenberg Black Shale event". However, the authors did not recognise a major fault in the outcrop, which causes duplication of the higher beds; the so-called Cymaclymenia involvens Zone is thus not justified. The beds assigned to this zone (unit R in figure 4 of Becker et al., 2002) are a repetition of unit J1 (i.e. a rock unit below the "Hangenberg Black Shale event").

\section{Cymaclymenia serotina $\mathbf{n} . \mathbf{s p}$.}

\section{Figure 24}

Derivation of name: After Lat. serotinus, - $a$, - um (adj.) = delayed; because of the late stratigraphic occurrence.

Holotype: Specimen MB.C.22605.1 (Korn 1995 Coll.); illustrated here in Fig. 24a.

Type locality and horizon: Erfoud (Anti-Atlas), immediately east of the Muslim cemetery on the eastern side of the Ziz Valley; bed 55 of Korn (1999), Parawocklumeria paradoxa Assemblage (late Famennian).

Material: 10 specimens with a maximum conch diameter of $45 \mathrm{~mm}$.

Diagnosis: Species of Cymaclymenia with thinly discoidal conch in the adult stage $(\mathrm{ww} / \mathrm{dm}=0.30)$; whorl cross section weakly compressed $(\mathrm{ww} / \mathrm{wh}=0.65)$. Conch shape in the intermediate stage $(10 \mathrm{~mm} \mathrm{dm})$ thinly discoidal and subinvolute $(\mathrm{ww} / \mathrm{dm}=0.33$; $\mathrm{uw} / \mathrm{dm}=0.25-0.30)$. Umbilical wall oblique in the adult stage, flanks moderately converging, venter rounded. Ornament with almost smooth and extremely fine biconvex growth lines, without riblets.

Discussion: $C$. serotina differs from nearly all other species of the genus in the very faint conch ornament. The species differs from Cymaclymenia formosa and the other Moroccan species with slender conchs by the extremely fine ornament, 

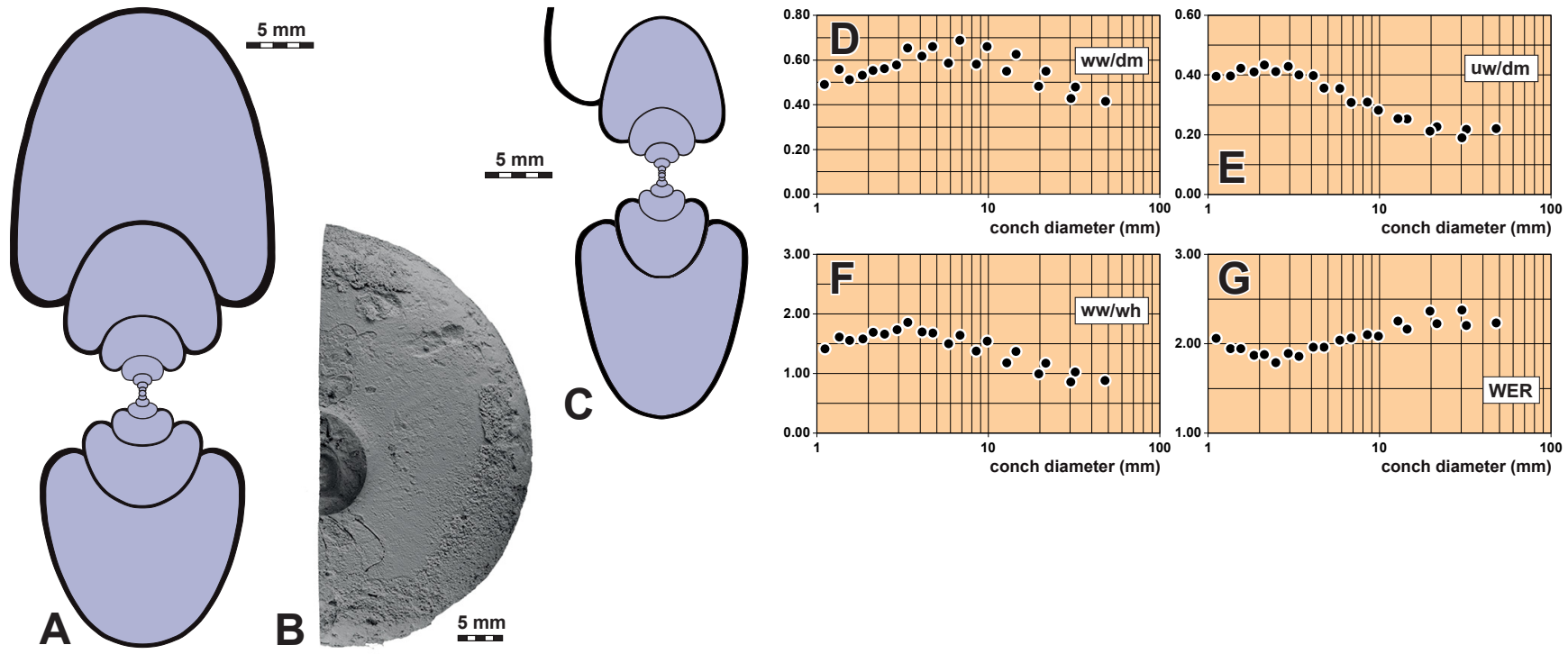

Figure 26. Cross sections $(\mathbf{A}, \mathbf{C}$; all $\times 1.5)$, photograph $(\mathbf{B} ; \times 1.0)$ and ontogenetic trajectories $(\mathbf{D}-\mathbf{G})$ of Cymaclymenia carnata n. sp. from the Anti-Atlas of Morocco. (A, B) Holotype MB.C.22654 (Kullmann Coll.) from Aguelmous. (C) Paratype MB.C.22645 (Korn 2009 Coll.) from Madène el Mrakib. (D) Conch width index (ww/dm). (E) Umbilical width index (ww/wh). (F) Whorl width index (uw/dm). (G) Whorl expansion rate (WER).

Table 7. Conch ontogeny of Cymaclymenia carnata n. sp. from the Anti-Atlas of Morocco.

\begin{tabular}{|c|c|c|c|}
\hline $\mathrm{dm}$ & Conch shape & Whorl cross-section shape & Whorl expansion \\
\hline $2 \mathrm{~mm}$ & $\begin{array}{l}\text { thickly discoidal; subevolute } \\
\text { (ww / dm } \sim 0.65 ; \text { uw / dm } \sim 0.42 \text { ) }\end{array}$ & $\begin{array}{l}\text { moderately depressed; weakly embracing } \\
\text { (ww / wh } \sim 1.60 ; \mathrm{IZR} \sim 0.15 \text { ) }\end{array}$ & $\begin{array}{l}\text { moderate } \\
(\text { WER } \sim 1.85)\end{array}$ \\
\hline $6 \mathrm{~mm}$ & $\begin{array}{l}\text { thinly pachyconic; subevolute } \\
(\mathrm{ww} / \mathrm{dm} \sim 0.65 ; \mathrm{uw} / \mathrm{dm} \sim 0.35)\end{array}$ & $\begin{array}{l}\text { moderately depressed; weakly embracing } \\
\text { (ww / wh } \sim 1.60 ; \text { IZR } \sim 0.25 \text { ) }\end{array}$ & $\begin{array}{l}\text { high } \\
(\text { WER 2.05) }\end{array}$ \\
\hline $15 \mathrm{~mm}$ & $\begin{array}{l}\text { thinly pachyconic; subinvolute } \\
\text { (ww/ dm } \sim 0.60 ; \mathrm{uw} / \mathrm{dm} \sim 0.25 \text { ) }\end{array}$ & $\begin{array}{l}\text { weakly depressed; weakly embracing } \\
(\mathrm{ww} / \mathrm{wh} \sim 1.30 ; \mathrm{IZR}=0.25-0.30)\end{array}$ & $\begin{array}{l}\text { high } \\
(\text { WER } \sim 2.20)\end{array}$ \\
\hline $40 \mathrm{~mm}$ & $\begin{array}{l}\text { thinly discoidal; subinvolute } \\
(\mathrm{ww} / \mathrm{dm} \sim 0.45 ; \mathrm{uw} / \mathrm{dm} \sim 0.20 \text { ) }\end{array}$ & $\begin{array}{l}\text { weakly compressed; weakly embracing } \\
(\mathrm{ww} / \mathrm{wh} \sim 0.90 ; \mathrm{IZR}=0.25-0.30)\end{array}$ & $\begin{array}{l}\text { high } \\
(\text { WER } \sim 2.25)\end{array}$ \\
\hline
\end{tabular}

which consists of very delicate growth lines. In this respect it is similar to $C$. lambidia, but this species has a stouter conch.

\section{Cymaclymenia aulax $\mathbf{n}$. sp.}

Figure 25

Derivation of name: After Lat. aulax (noun) = furrow; because of the steinkern constrictions.

Holotype: Specimen MB.C.22651 (Ebbighausen 2008 Coll.); illustrated here in Fig. 25a.

Type locality and horizon: Aguelmous (Anti-Atlas); probably Kalloclymenia Assemblage (late Famennian).

Material: 3 specimens with a maximum conch diameter of $60 \mathrm{~mm}$.

Diagnosis: Species of Cymaclymenia with thinly discoidal and subevolute conch in the adult stage $(\mathrm{ww} / \mathrm{dm}=0.30 ; \mathrm{uw} / \mathrm{dm}=$ 0.30 ); whorl cross section weakly compressed ( $\mathrm{ww} / \mathrm{wh}=0.65$ ).
Umbilical wall steep in the adult stage, flanks weakly converging, venter rounded. Ornament with rather coarse biconvex growth lines, without riblets; steinkern with curved constrictions on the flanks.

Discussion: $C$. aulax belongs to the few species of the genus with coarse steinkern constrictions. Münster (1832) described the species "Planulites semistriatus" from Franconia, which also belongs to Cymaclymenia. This species also possesses steinkern constrictions on the flanks and venter. $C$. semistrata has a very slender conch $(\mathrm{ww} / \mathrm{dm}=0.26$ at $30 \mathrm{~mm} \mathrm{dm}$ ) in contrast to the stouter $C$. aulax (ww/ dm = 0.32 at a comparable diameter). C. sudetica (Renz, 1914) from Silesia possesses steinkern constrictions, but has a stouter conch shape.

The new species differs from the other species of Cymaclymenia from the Anti-Atlas by the presence of conspicuous steinkern constrictions. $C$. formosa is the most similar of the 

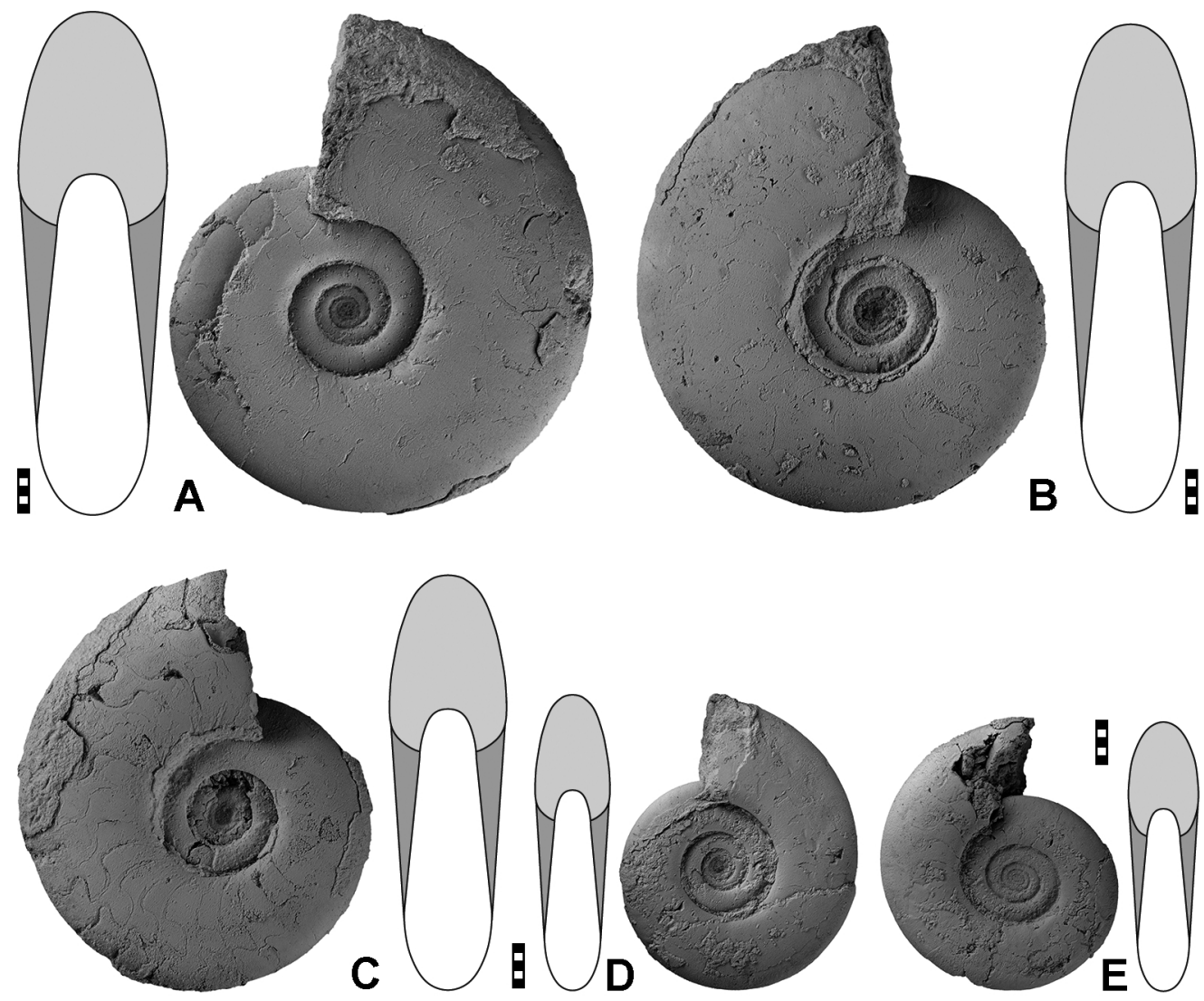

Figure 27. Postclymenia calceola n. sp. from Lalla Mimouna (Anti-Atlas of Morocco); all × 1.0. (A) Paratype MB.C.22662.2 (Ebbighausen 2005 Coll.). (B) Holotype MB.C.22662.1 (Ebbighausen 2005 Coll.). (C) Paratype MB.C.22662.3 (Ebbighausen 2005 Coll.). (D) Paratype MB.C.22663.1 (Korn 2005 Coll.). (E) Paratype MB.C.22663.2 (Korn 2005 Coll.).

other species, but $C$. aulax also differs in the increasing umbilical width index in the adult stage.

\section{Cymaclymenia carnata $\mathbf{n}$. sp.}

Figure 26

Derivation of name: After Lat. carnatus, $-a$, $-u m$ (adj.) = thick; because of the stout conch form.

Holotype: Specimen MB.C.22654 (Kullmann Coll.); illustrated here in Fig. 26a, b.

Type locality and horizon: Aguelmous; probably Kalloclymenia Assemblage (late Famennian).

Material: 2 specimens with a maximum conch diameter of $55 \mathrm{~mm}$.

Diagnosis: Species of Cymaclymenia with thinly discoidal conch in the adult stage ( $\mathrm{ww} / \mathrm{dm}=0.42$ ); whorl cross section weakly compressed $(\mathrm{ww} / \mathrm{wh}=0.90)$. Conch shape in the intermediate stage $(10 \mathrm{~mm} \mathrm{dm})$ thinly pachyconic and subinvolute $(\mathrm{ww} / \mathrm{dm}=0.62$; $\mathrm{uw} / \mathrm{dm}=0.28$ ). Umbilical wall steep in the adult stage, flanks moderately converging, venter broadly rounded. Ornament with fine biconvex growth lines, without riblets.
Discussion: Cymaclymenia carnata has, together with $C$. nephroides, the stoutest conch of all Cymaclymenia species. The two species can be separated by the umbilical width; $C$. carnata is more involute $(\mathrm{ww} / \mathrm{dm}=0.20)$ than $C$. nephroides $(\mathrm{uw} / \mathrm{dm}=$ $0.25)$.

\section{Postclymenia Schmidt, 1924}

Type species: Postclymenia evoluta Schmidt, 1924, p. 154 (by monotypy).

Genus definition: Genus of the Cymaclymeniidae with thinly discoidal, weakly ornamented conch. Suture line with large, extremely asymmetric and ventrally elongated lateral lobe. Umbilical lobe widely rounded.

The genus consists only of two species: the type species and a new species described here. For a discussion of the genus, see Korn et al. (2004) and Korn et al. (2007).

\section{Postclymenia calceola $\mathbf{n}$. sp.}

Figures 27 and 28

2004 Postclymenia evoluta. - Korn et al., p. 315, fig. 6A-D, 8.

2007 Postclymenia evoluta. - Korn et al., p. 137, fig. 8. 

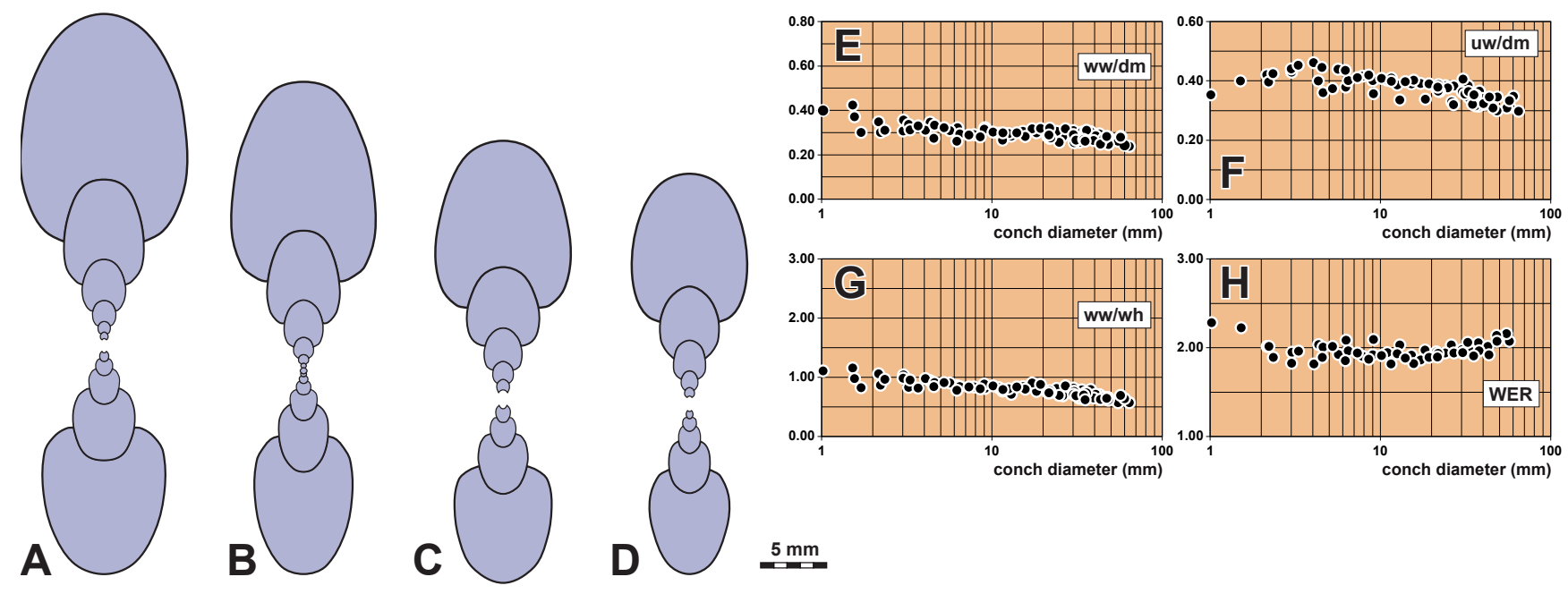

Figure 28. Cross sections $(\mathbf{A}-\mathbf{D}$; all $\times 1.5)$ and ontogenetic trajectories $(\mathbf{E}-\mathbf{H})$ of Postclymenia calceola $\mathrm{n}$. sp. from Lalla Mimouna (AntiAtlas of Morocco). (A) Paratype MB.C.9302.2 (Ebbighausen 2005 Coll.). (B) Paratype MB.C.9302.1 (Ebbighausen 2005 Coll.). (C) Paratype MB.C.9302.3 (Ebbighausen 2005 Coll.). (D) Paratype MB.C.9302.4 (Ebbighausen 2005 Coll.). (E) Conch width index (ww / dm). (F) Umbilical width index (ww/wh). (G) Whorl width index (uw/dm). (H) Whorl expansion rate (WER).

Table 8. Conch ontogeny of Postclymenia calceola n. sp. from the Anti-Atlas of Morocco.

\begin{tabular}{|c|c|c|c|}
\hline $\mathrm{dm}$ & Conch shape & Whorl cross-section shape & Whorl expansion \\
\hline $2 \mathrm{~mm}$ & $\begin{array}{l}\text { thinly discoidal; subevolute } \\
(\mathrm{ww} / \mathrm{dm}=0.30-0.35 ; \mathrm{uw} / \mathrm{dm}=0.40-0.42)\end{array}$ & $\begin{array}{l}\text { weakly depressed or weakly compressed; } \\
\text { weakly embracing } \\
(\text { ww } / \text { wh }=0.90-1.10 ; \mathrm{IZR}=0.10-0.15)\end{array}$ & $\begin{array}{l}\text { moderate } \\
(\mathrm{WER}=1.90-2.00)\end{array}$ \\
\hline $6 \mathrm{~mm}$ & $\begin{array}{l}\text { thinly discoidal; subevolute } \\
(\mathrm{ww} / \mathrm{dm}=0.30-0.35 ; \mathrm{uw} / \mathrm{dm}=0.40-0.45)\end{array}$ & $\begin{array}{l}\text { weakly compressed; weakly embracing } \\
(\mathrm{ww} / \mathrm{wh}=0.90-1.00 ; \mathrm{IZR}=0.15-0.20)\end{array}$ & $\begin{array}{l}\text { moderate } \\
(\mathrm{WER}=1.90-2.00)\end{array}$ \\
\hline $15 \mathrm{~mm}$ & $\begin{array}{l}\text { thinly discoidal; subevolute } \\
(\mathrm{ww} / \mathrm{dm}=0.30-0.35 ; \mathrm{uw} / \mathrm{dm}=0.38-0.42)\end{array}$ & $\begin{array}{l}\text { weakly depressed or weakly compressed; } \\
\text { weakly embracing } \\
(\text { ww } / \text { wh }=0.80-0.90 ; \text { IZR }=0.20-0.25 \text { ) }\end{array}$ & $\begin{array}{l}\text { moderate } \\
(\mathrm{WER}=1.90-2.00)\end{array}$ \\
\hline $40 \mathrm{~mm}$ & $\begin{array}{l}\text { thinly discoidal; subevolute } \\
(\mathrm{ww} / \mathrm{dm}=0.25-0.30 ; \mathrm{uw} / \mathrm{dm}=0.30-0.35)\end{array}$ & $\begin{array}{l}\text { weakly depressed or weakly compressed; } \\
\text { weakly embracing } \\
(\mathrm{ww} / \mathrm{wh}=0.70-0.75 ; \mathrm{IZR}=0.25)\end{array}$ & $\begin{array}{l}\text { high } \\
(\text { WER }=2.00-2.10)\end{array}$ \\
\hline
\end{tabular}

Derivation of name: After Lat. calceolus (noun) = little boot; because of the shape of the lateral lobe.

Holotype: Specimen MB.C.22662.1 (Ebbighausen 2005 Coll.); illustrated here in Fig. 27b.

Type locality and horizon: Lalla Mimouna (Anti-Atlas); latest Famennian.

Material: 119 specimens with a maximum phragmocone diameter of $60 \mathrm{~mm}$.

Diagnosis: Species of Postclymenia with thinly discoidal conch in the adult stage ( $w w / d m=0.25-0.30)$; whorl cross section weakly compressed $(\mathrm{ww} / \mathrm{wh}=0.70)$. Suture line with strongly asymmetric, pouched boot-shaped lateral lobe.
Discussion: Postclymenia evoluta has a very similar or nearly identical conch but differs from the new species in the suture line, which possesses a smaller adventive lobe with a vertical ventral side of the adventive lobe, as figured by Schmidt (1924, pl. 8, fig. 19) and Price and Korn (1989, fig. 11A). For a detailed description and discussion of the new species, see Korn et al. (2004) and Korn et al. (2007).

Acknowledgements. We are indebted to the Moroccan authorities for their permission for us to undertake field work. We greatly acknowledge the late Volker Ebbighausen (deceased 2011), Raimund Feist (Montpellier), Jürgen Kullmann (Tübingen), Martin Rücklin (Leiden), Jobst Wendt (Tübingen) and Dieter Weyer (Berlin) for providing specimens. Evelin Stenzel (Berlin) cleaned the specimens from the matrix. Jonas Jahn (Berlin) is acknowledged for taking the photographs, and Sonny A. Walton (Potsdam) revised 
the language of the manuscript. We acknowledge the reviews of the article by Jürgen Bockwinkel (Leverkusen), Claude Monnet (Lille) and Alan L. Titus (Kanab, Utah).

Edited by: F. Witzmann

Reviewed by: J. Bockwinkel, C. Monnet, and A. Titus

\section{References}

Adams, D., Rohlf, F. J., and Slice, D.: Geometric morphometrics: Ten years of progress following the "revolution", Ital. J. Zool., 71, 5-16, 2004.

Becker, R. T., Bockwinkel, J., Ebbighausen, V., and House, M. R.: Jebel Mrakib, Anti-Atlas (Morocco), a potential Upper Famennian substage boundary stratotype section, Notes et Mémoires, Service des Mines et de la carte géologique du Maroc, 399, 75$86,2000$.

Becker, R. T., House, M. R., Bockwinkel, J., Ebbighausen, V., and Aboussalam, Z. S.: Famennian ammonoid zones of the eastern Anti-Atlas (southern Morocco), Münstersche Forschungen zur Geologie und Paläontologie, 93, 159-205, 2002.

Bogoslovsky, B. I.: Sistematika i filogeniya klimeniin, Paleontol. Zh., 1979, 32-47, 1979.

Bookstein, F. L.: Morphometric tools for landmark data: geometry and biology, New York, Cambridge Univsity Press, 1991.

Bookstein, F. L.: A hundred years of morphometrics, Acta Zool. Acad. Sci. H., 44, 7-59, 1998.

Cheverud, J. M.: Relationships Among Ontogenetic, Static, and Evolutionary Allometry, Am. J. Phys. Anthropol., 59, 139-149, 1982.

Clausen, C.-D., Korn, D., and Uffenorde, H.: Das Devon/KarbonProfil am alten Schießstand bei der Bilsteinhöhle (Blat 4515 Hirschberg, Warsteiner Sattel, Rheinisches Schiefergebirge), Aufschluß, 29, 47-68, 1979.

Crampton, J. S.: Elliptic Fourier shape analysis of fossil bivalves: some practical considerations, Lethaia, 28, 179-186, 1995.

Czarnocki, J.: Klimenie Gór Swietokrzyskich, Prace Panstwowego Instytutu Geologicznego, 127, 1-91, 1989.

Ferson, S., Rohlf, F. J., and Koehn, R. K.: Measuring shape variation of two-dimensional outlines, Syst. Biol., 34, 59-68, 1985.

Fisher, R. A.: The logic of inductive inference, J. R. Stat. Soc., 98, 39-82, 1935.

Gould, S. J.: Allometry and size in ontogeny and phylogeny, Biol. Rev., 41, 587-638, 1966.

Gould, S. J.: Ontogeny and phylogeny, Boston, Massachusetts, Harvard University Press, 1977.

Haines, A. J. and Crampton, J. S.: Improvements to the method of Fourier shape analysis as applied in morphometric studies, Palaeontology, 43, 765-783, 2000.

Hotelling, H.: Analysis of a complex of statistical variables into principal components, J. Educ. Psychol., 24, 417-441, 1933.

Huxley, J. S.: Constant differential growth-ratios and their significance, Nature, 114, 895-896, 1924.

Huxley, J. S.: Problems of Relative Growth, Reprinted 1993, Baltimore, Johns Hopkins University Press, 1932.

Huxley, J. S. and Teissier, G.: Terminology of relative growth, Nature, 137, 780-781, 1936.

Hyatt, A.: Genera of fossil cephalopods, Proceedings of the Boston Society of Natural History, 253-338, 1984.
Kant, R.: Allometrisches Wachstum paläozoischer Ammonoideen: Variabilität und Korrelation einiger Merkmale, Neues Jahrb. Geol. P.-A., 143, 153-192, 1973.

Klingenberg, C. P.: Multivariate allometry, in: Advances in morphometrics. NATO advanced science institutes series, Series A, Life Sciences, edited by: Marcus, L., Corti, M., Loy, A., Naylor, G., and Slice, D., 1996.

Klingenberg, C. P.: Heterochrony and allometry: the analysis of evolutionary change in ontogeny, Biol. Rev., 73, 79-123, 1998.

Klingenberg, C. P. and Froese, R.: A multivariate comparison of allometric growth-patterns, Syst. Zool., 40, 410-419, 1991.

Korn, D.: Cymaclymenia - eine besonders langlebige ClymenienGattung (Ammonoidea, Cephalopoda), Neues Jahrb. Geol. P.-A., 161, 172-208, 1981.

Korn, D.: Threedimensionally preserved clymeniids from the Hangenberg Black Shale of Drewer (Cephalopoda, Ammonoidea; Devonian-Carboniferous boundary; Rhenish Massif), Neues Jahrb. Geol. P.-A., Monatshefte, 1991, 553-563, 1991.

Korn, D.: Famennian Ammonoid Stratigraphy of the Ma'der and Tafilalt (Eastern Anti-Atlas, Morocco, Abhandlungen der Geologischen Bundesanstalt, 54, 147-179, 1999.

Korn, D.: A key for the description of Palaeozoic ammonoids, Fossil Record, 13, 5-12, doi:10.1002/mmng.200900008, 2010.

Korn, D.: Quantification of ontogenetic allometry in ammonoids, Evol. Dev., 14, 501-514, 2012.

Korn, D. and Ilg, A.: AMMON. Database of Palaeozoic Ammonoidea, http://www.wahre-staerke.com/ammon/, 2007.

Korn, D. and Klug, C.: Ammoneae Devonicae, edited by: Riegraf, W., Vol. 138, Fossilium Catalogus, I: Animalia, Backhuys, 2002.

Korn, D. and Klug, C.: Morphological pathways in the evolution of Early and Middle Devonian ammonoids, Paleobiology, 29, 329348, 2003.

Korn, D. and Klug, C.: Conch form analysis, variability, morphological disparity, and mode of life of the Frasnian (Late Devonian) ammonoid Manticoceras from Coumiac (Montagne Noire, France), in: Cephalopods Present and Past: New Insights and Fresh Perspectives, edited by: Landman, N. H., Davis, R. A., and Mapes, R. H., New York, Springer, 2007.

Korn, D., Belka, Z., Fröhlich, S., Rücklin, M., and Wendt, J.: The youngest African clymeniids (Ammonoidea, Late Devonian) failed survivors of the Hangenberg Event, Lethaia, 37, 307-315, 2004.

Korn, D., Bockwinkel, J., and Ebbighausen, V.: Tournaisian and Visean ammonoid stratigraphy in North Africa, Neues Jahrb. Geol. P.-A., 243, 127-148, 2007.

Kuhl, F. and Giardinia, C. R.: Elliptic Fourier features of a closed contour, Comput. Vision Graph., 18, 236-258, 1982.

Kullmann, J.: Die Ammonoidea des Devon im Kantabrischen Gebirge (Nordspanien), Abhandlungen der Akademie der Wissenschaften und der Literatur in Mainz, mathematischnaturwissenschaftliche Klasse, 1960, 1-105, 1960.

Kullmann, J. and Scheuch, J.: Wachstums-Änderungen in der Ontogenese paläozoischer Ammonoideen, Lethaia, 3, 397-412, 1970.

Lange, W.: Zur Kenntnis des Oberdevons am Enkeberg und bei Balve (Sauerland), Abhandlungen der Preußischen Geologischen Landesanstalt, Neue Folge 119, 1-132, 1929.

Loewinson-Lessing, F.: Les ammonées de la zone a Sporadoceras Münsteri dans les monts Gouberlinskya Gory (gouv. 
d'Orenburg), Oural méridional, Bulletin de la Societé belge de Géologie, 6, 15-25, 1892.

MacLeod, N.: Phylogenetic signals in morphometric data, in: Morphology, Shape and Phylogeny, edited by: MacLeod, N., and Forey, P. L., London, New York, Taylor \& Francis, 2002.

McCoy, F.: On some new Devonian Fossils, Annual Magazine of Natural History, 28, 481-489, 1851.

McNamara, K. J.: A guide to the nomenclature of heterochrony, J. Paleontol., 60, 4-13, 1986.

Mitteroecker, P. and Gunz, P.: Advances in geometric morphometrics, Evol. Biol., 36, 235-247, 2009.

Münster, G. Graf zu: Ueber die Planuliten und Goniatiten im Uebergangs-Kalk des Fichtelgebirges, Bayreuth, Birner, 1832.

Münster, G. Graf zu: Die Versteinerungen des Uebergangskalkes mit Clymenien und Orthoceratiten von Oberfranken, Beiträge zur Petrefactenkunde, 3, 33-121, 1840.

Münster, G. Graf zu: Nachtrag zu den Versteinerungen des Uebergangskalkes mit Clymenien, Beiträge zur Petrefactenkunde, 6, 112-130, 1842.

Nikolaeva, S. V. and Bogoslovsky, B. I.: Devonskie ammonoidei: IV. Klimenii (podotryad Clymeniina), Trudy Paleontologicheskogo Instituta Rossiyskaya Akademiya Nauk, 1, 1-214, 2005.

Pearson, K.: Note on regression and inheritance in the case of two parents, P. R. Soc. London, 58, 240-242, 1895.

Pearson, K.: On lines and planes of closest fit to systems of points in space, The London, Edinburgh, and Dublin Philosophical Magazine and Journal of Science, 2, 559-572, 1901.

Petter, G.: Goniatites dévoniennes du Sahara, Publications du Service de la Carte géologique de l'Algérie (nouvelle série), Paléontologie, 2, 1-313, 1959.

Petter, G.: Clymènies du Sahara, Publications du Service de la Carte géologique de l'Algérie (nouvelle série), Paléontologie, 6, 1-58, 1960.

Pickett, J. W.: A clymeniid from the Wocklumeria zone of New South Wales, Palaeontology, 3, 237-241, 1960.

Price, J. D. and Korn, D.: Stratigraphically important Clymeniids (Ammonoidea) from the Famennian (Later Devonian) of the Rhenish Massif, West Germany, Cour. For. Sekenbg., 11, 257294, 1989.

Raup, D. M.: Geometric analysis of shell coiling: general problems, J. Paleontol., 40, 1178-1190, 1966.

Raup, D. M.: Geometric analysis of shell coiling: coiling in ammonoids, J. Paleontol., 41, 43-65, 1967.

Raup, D. M. and Michelson, A.: Theoretical Morphology of the Coiled Shell, Science, 147, 1294-1295, 1965.

Renz, C.: Neue Arten aus dem Clymenienkalk von Ebersdorf in Schlesien, Jahrbuch der Preußischen Geologischen Landesanstalt, 34, 99-129, 1914.

Rohlf, F. J.: tpsDig 2.10, Stony Brook, NY: Department of Ecology and Evolution, State University of New York, 2006.

Rohlf, F. J. and Marcus, L. F.: A revolution morphometrics, Trends Ecol. Evol., 8, 129-132, 1993.
Ruan, Y.-p. and He, G.: Devonian Ammonoids, in: A handbook of the stratigraphy and paleontology in Southwest China, edited by: Nanjing Institute of Geology and Paleontology, Academia Sinica, 238-239, 1974.

Schindewolf, O. H.: Beiträge zur Kenntnis des Paläozoikums in Oberfranken, Ostthüringen und dem Sächsischen Vogtlande. I. Stratigraphie und Ammoneenfauna des Oberdevons von Hof a.S., Neues Jahrbuch für Mineralogie, Geologie und Paläontologie, Beilage-Band, 49, 250-357, 393-509, 1923.

Schindewolf, O. H.: Zur Stratigraphie und Paläontologie der Wocklumer Schichten (Oberdevon), Abhandlungen der Preußischen Geologischen Landesanstalt, Neue Folge, 178, 1-132, 1937.

Schmidt, H.: Zwei Cephalopodenfaunen an der DevonCarbongrenze im Sauerland, Jahrbuch der Preußischen Geologischen Landesanstalt, 44, 98-171, 1924.

Selwood, E. B.: Amonoids and Trilobites from the Upper Devonian and lowest Carboniferous of the Launceston area of Cornwall, Palaeontology, 3, 153-185, 1960.

Simon, M. S., Korn, D., and Koenemann, S.: Disparity fluctuations in Jurassic ammonoids by means of conch geometry, Palaeogeogr. Palaeocl., 292, 520-531, 2010.

Simon, M. S., Korn, D., and Koenemann, S.: Temporal patterns in disparity and diversity of the Jurassic ammonoids of southern Germany, Fossil Record, 14, 77-94, doi:10.1002/mmng.201000016, 2011.

Sun, Y.-z. and Shen, Y.-t.: On the late Upper Devonian ammonite fauna of the Wocklumeria beds of south Kweichow and its stratigraphical significance, Professional Papers of the Academy of Geological Science, Ministry of Geology, section B, 1, 33-100, 1965.

Temple, J. T.: The progress of quantitative methods in palaeontology, Palaeontology, 35, 475-484, 1992.

Wedekind, R.: Die Cephalopodenfauna des höheren Oberdevon am Enkeberge, Neues Jahrbuch für Mineralogie, Geologie und Paläontologie, Beilage-Band, 26, 565-633, 1908.

Wedekind, R.: Monographie der Clymenien des Rheinischen Gebirges, Abhandlungen kgl. Ges. Wiss. Göttingen, Math.-Phys. K1., N.F., 10, 1-73, 1914.

Wendt, J.: Disintegration of the continental margin of northwestern Gondwana: Late Devonian of the eastern Anti-Atlas (Morocco), Geology, 13, 815-818, 1985.

Wendt, J.: Facies pattern and palaeogeography of the Middle and Late Devonian in the eastern Anti-Atlas (Morocco), in: Devonian of the world. Proceedings of the 2nd International Symposium on the Devonian System, Calgary, edited by: McMillan, N. J., Embry, A. F., and Glass, D. J., Calgary, 1988.

Wills, M. A.: Morphological disparity: a primer, in: Fossils phylogeny and form. An analytical approach, edited by: Adrain, J. M., Edgecombe, G. D., and Lieberman, B. S., New York, Boston, Dordrecht, London, Moscow, Kluwer Academic/Plenum Publishers, 2001. 


\section{Appendix A}

Table A1. List of the studied material from the Anti-Atlas of Morocco.

\begin{tabular}{|c|c|c|c|}
\hline Locality & Collection & Species & $n$ \\
\hline Bordj d'Erfoud, bed 55 & Korn 1995 & Cymaclymenia lambidia & 58 \\
\hline Bordj d'Erfoud, bed 55 & Korn 1995 & Cymaclymenia serotina & 10 \\
\hline Bordj d'Erfoud, bed 54 & Korn 1995 & Cymaclymenia formosa & 1 \\
\hline Bordj d'Erfoud, bed 52 & Korn 1995 & Cymaclymenia formosa & 3 \\
\hline Bordj d'Erfoud, bed 50 & Korn 1995 & Cymaclymenia formosa & 1 \\
\hline Bordj d'Erfoud, bed 49-50 & Korn 1995 & Cymaclymenia formosa & 8 \\
\hline Bordj d'Erfoud, bed 49 & Korn 1995 & Cymaclymenia formosa & 31 \\
\hline Bordj d'Erfoud, bed 48 & Korn 1995 & Cymaclymenia formosa & 48 \\
\hline Bordj d'Erfoud, bed $47+48$ & Korn 1995 & Cymaclymenia formosa & 3 \\
\hline Bordj d'Erfoud, bed 47 & Korn 1995 & Cymaclymenia formosa & 19 \\
\hline Bordj d'Erfoud, bed 45-46 & Korn 1995 & Cymaclymenia formosa & 2 \\
\hline Bordj d'Erfoud, bed 43-44 & Korn 1995 & Cymaclymenia formosa & 2 \\
\hline Bordj d'Erfoud, bed $41+42$ & Korn 1995 & Cymaclymenia formosa & 2 \\
\hline Bordj d'Erfoud, bed 39-40 & Korn 1995 & Cymaclymenia formosa & 4 \\
\hline Madène el Mrakib, sample 19 & Korn 1998 & Procymaclymenia ebbighauseni & 32 \\
\hline Madène el Mrakib, surface collection & Ebbighausen and Korn 2009 & Procymaclymenia ebbighauseni & 4 \\
\hline Madène el Mrakib, Procymacl. Lst. & Ebbighausen and Korn 2009 & Procymaclymenia ebbighauseni & 19 \\
\hline Madène el Mrakib, sample 2009-14 & Ebbighausen and Korn 2009 & Procymaclymenia ebbighauseni & 5 \\
\hline Madène el Mrakib, sample 2009-13 & Ebbighausen and Korn 2009 & Procymaclymenia ebbighauseni & 2 \\
\hline Madène el Mrakib, sample 2009-10 & Ebbighausen and Korn 2009 & Procymaclymenia ebbighauseni & 5 \\
\hline Madène el Mrakib, sample 2008 2.x & Ebbighausen and Korn 2008 & Procymaclymenia ebbighauseni & 15 \\
\hline Madène el Mrakib, sample 20082.6 & Ebbighausen and Korn 2008 & Procymaclymenia ebbighauseni & 14 \\
\hline Madène el Mrakib, sample 2010-3 & Ebbighausen and Korn 2010 & Procymaclymenia ebbighauseni & 34 \\
\hline Madène el Mrakib, top 10 m & Feist 1990 & Cymaclymenia lambidia & 2 \\
\hline Madène el Mrakib, top $10 \mathrm{~m}$ & Feist 1990 & Cymaclymenia formosa & 2 \\
\hline Madène el Mrakib, $10-15 \mathrm{~m}$ from top & Feist 1990 & Cymaclymenia lambidia & 2 \\
\hline Madène el Mrakib, $10-15 \mathrm{~m}$ from top & Feist 1990 & Cymaclymenia subvexa & 3 \\
\hline Madène el Mrakib, $30-40 \mathrm{~m}$ from top & Feist 1990 & Procymaclymenia ebbighauseni & 2 \\
\hline Madène el Mrakib, $15 \mathrm{~m}$ from top & Korn 1998 & Cymaclymenia subvexa & 1 \\
\hline Madène el Mrakib, 0-5 m from top & Korn 1998 & Cymaclymenia lambidia & 10 \\
\hline Madène el Mrakib, 0-5 m from top & Korn 1998 & Cymaclymenia formosa & 1 \\
\hline Madène el Mrakib, float & Korn 1998 & Cymaclymenia subvexa & 6 \\
\hline Madène el Mrakib, sample 15 & Korn 1998 & Cymaclymenia subvexa & 10 \\
\hline Madène el Mrakib, float & Korn 2010 & Cymaclymenia formosa & 6 \\
\hline Madène el Mrakib, float & Korn 2009 & Cymaclymenia formosa & 6 \\
\hline Madène el Mrakib, float & Korn 2009 & Cymaclymenia lambidia & 2 \\
\hline Madène el Mrakib, float & Korn 2009 & Cymaclymenia carnata & 1 \\
\hline Madène el Mrakib, float & Korn 2009 & Cymaclymenia subvexa & 2 \\
\hline Madène el Mrakib, float & Weyer 2009 & Cymaclymenia formosa & 1 \\
\hline Madène el Mrakib, float & Ebbighausen & Cymaclymenia subvexa & 24 \\
\hline Madène el Mrakib, float & Ebbighausen 2005 & Cymaclymenia subvexa & 1 \\
\hline Madène el Mrakib, float & Ebbighausen 2009 & Cymaclymenia subvexa & 2 \\
\hline Madène el Mrakib, float & Ebbighausen 2008 & Cymaclymenia subvexa & 17 \\
\hline Madène el Mrakib, float & Ebbighausen 1994 & Cymaclymenia subvexa & 4 \\
\hline Madène el Mrakib, float & Ebbighausen 1999 & Cymaclymenia subvexa & 9 \\
\hline Madène el Mrakib, float & Ebbighausen & Cymaclymenia lambidia & 1 \\
\hline Lambidia (Aguelmous), float & Korn 2009 & Cymaclymenia lambidia & 2 \\
\hline Lambidia (Aguelmous), float & Korn 2009 & Cymaclymenia formosa & 10 \\
\hline Lambidia (Aguelmous), float & Ebbighausen 2003 & Cymaclymenia aulax & 1 \\
\hline Lambidia (Aguelmous), bed K & Ebbighausen 2000 & Cymaclymenia lambidia & 18 \\
\hline Lambidia (Aguelmous), float & Ebbighausen 2009 & Cymaclymenia lambidia & 6 \\
\hline Lambidia (Aguelmous), float & Ebbighausen 2000 & Cymaclymenia formosa & 37 \\
\hline Lambidia (Aguelmous), float & Ebbighausen 2008 & Cymaclymenia aulax & 1 \\
\hline
\end{tabular}


Table A1. Continued.

\begin{tabular}{|c|c|c|c|}
\hline Locality & Collection & Species & $n$ \\
\hline Lambidia (Aguelmous), float & Kullmann & Cymaclymenia lambidia & 5 \\
\hline Lambidia (Aguelmous), float & Kullmann & Cymaclymenia carnata & 1 \\
\hline Lambidia (Aguelmous), float & Ebbighausen and Weyer 2006 & Cymaclymenia lambidia & 6 \\
\hline Lambidia (Aguelmous), float & Korn 2006 & Cymaclymenia formosa & 1 \\
\hline Bou Tchrafine, Gonioclymenia bed & Korn 1993 & Cymaclymenia subvexa & 18 \\
\hline Bou Ifarherioun $S$ & Korn 1993 & Cymaclymenia formosa & 8 \\
\hline Bou Ifarherioun & Rücklin 2003 & Cymaclymenia subvexa & 1 \\
\hline Bou Ifarherioun & Wendt & Cymaclymenia lambidia & 3 \\
\hline Bou Ifarherioun & Wendt & Cymaclymenia formosa & 1 \\
\hline Bou Ifarherioun & Wendt & Cymaclymenia subvexa & 1 \\
\hline Ouidane Chebbi, float & Korn 1993 & Cymaclymenia subvexa & 12 \\
\hline Ouidane Chebbi SE & Korn 1993 & Cymaclymenia formosa & 6 \\
\hline Ouidane Chebbi S & Korn 1993 & Cymaclymenia formosa & 4 \\
\hline El Atrous, $80 \mathrm{~cm}$ above Platycl. & Korn 1995 & Procymaclymenia ebbighauseni & 40 \\
\hline Taourirt (Fezzou), sample 5 & Ebbighausen 2009 & Cymaclymenia lambidia & 1 \\
\hline Taourirt (Fezzou), sample 5 & Ebbighausen 2009 & Cymaclymenia formosa & 7 \\
\hline Taourirt (Fezzou), sample 4 & Ebbighausen 2009 & Cymaclymenia subvexa & 37 \\
\hline Taourirt (Fezzou), sample 3 & Ebbighausen 2009 & Cymaclymenia subvexa & 1 \\
\hline Taourirt (Fezzou), sample 2 & Ebbighausen 2009 & Cymaclymenia subvexa & 16 \\
\hline Taourirt (Fezzou), sample 1 & Ebbighausen 2009 & Procymaclymenia ebbighauseni & 14 \\
\hline Taourirt (Fezzou), Goniocl. horizon & Ebbighausen 2007 & Cymaclymenia subvexa & 65 \\
\hline Taourirt (Fezzou), float & Ebbighausen 2007 & Cymaclymenia lambidia & 3 \\
\hline Tanout el Bidiya & Ebbighausen & Procymaclymenia ebbighauseni & 3 \\
\hline Southern Ma'der Basin & Ebbighausen 1997 & Cymaclymenia subvexa & 104 \\
\hline Rich Bou Kourazia & Ebbighausen & Cymaclymenia subvexa & 2 \\
\hline Rich Bou Kourazia & Ebbighausen 1994 & Procymaclymenia ebbighauseni & 15 \\
\hline Rich Bou Kourazia & Ebbighausen 1997 & Procymaclymenia ebbighauseni & 46 \\
\hline Hamar Laghdad & Wendt & Cymaclymenia formosa & 1 \\
\hline Hamar Laghdad E & Wendt & Cymaclymenia formosa & 18 \\
\hline Bou Dib-Aguelmous & Wendt & Cymaclymenia formosa & 11 \\
\hline Rich Sidi Ali & Wendt & Procymaclymenia ebbighauseni & 2 \\
\hline Aguelmous NNE & Wendt & Cymaclymenia formosa & 3 \\
\hline Hassi Tissedimine & Wendt & Cymaclymenia formosa & 1 \\
\hline Fezzou-Aguelmous & Wendt & Cymaclymenia lambidia & 1 \\
\hline Fezzou-Aguelmous & Wendt & Cymaclymenia formosa & 1 \\
\hline Fezzou-Aguelmous & Wendt & Cymaclymenia subvexa & 13 \\
\hline Taourirt & Wendt & Cymaclymenia subvexa & 3 \\
\hline Taourirt & Wendt & Cymaclymenia formosa & 2 \\
\hline Rich bel Ras & Wendt & Cymaclymenia formosa & 2 \\
\hline Rich bel Ras & Wendt & Cymaclymenia subvexa & 3 \\
\hline Khorb el Attil & Wendt & Cymaclymenia subvexa & 2 \\
\hline Fezzou & Ebbighausen & Cymaclymenia subvexa & 3 \\
\hline Fezzou & Ebbighausen & Cymaclymenia aulax & 1 \\
\hline Fezzou & Ebbighausen 1988 & Cymaclymenia subvexa & 23 \\
\hline Bou Tlidat (Aguelmous) & Ebbighausen & Cymaclymenia lambidia & 4 \\
\hline Bou Tlidat (Aguelmous) & Ebbighausen & Cymaclymenia formosa & 9 \\
\hline Bou Tlidat (Aguelmous) & Ebbighausen 2008 & Cymaclymenia lambidia & 4 \\
\hline Bou Tlidat (Aguelmous) & Ebbighausen & Cymaclymenia formosa & 5 \\
\hline Lalla Mimouna & Ebbighausen 2005 & Postclymenia calceola & 73 \\
\hline Lalla Mimouna & Ebbighausen 2010 & Postclymenia calceola & 13 \\
\hline Lalla Mimouna & Korn 2005 & Postclymenia calceola & 33 \\
\hline
\end{tabular}


Table A2. Conch measurements and ratios of selected specimens of Cymaclymenia and related genera.

\begin{tabular}{|c|c|c|c|c|c|c|c|c|c|c|}
\hline & $\mathrm{dm}$ & ww & wh & uw & ah & $\mathrm{ww} / \mathrm{dm}$ & ww / wh & $\mathrm{uw} / \mathrm{dm}$ & WER & IZR \\
\hline \multicolumn{11}{|c|}{ Procymaclymenia ebbighauseni $\mathrm{n}$. sp. } \\
\hline MB.C.22619.1 & 40.24 & 12.19 & 18.29 & 9.39 & 13.04 & 0.30 & 0.67 & 0.23 & 2.19 & 0.29 \\
\hline MB.C.22621.1 & 35.57 & 9.45 & 16.22 & 8.86 & 11.52 & 0.27 & 0.58 & 0.25 & 2.19 & 0.29 \\
\hline MB.C.22665.2 & 27.80 & 8.78 & 13.33 & 5.44 & 9.35 & 0.32 & 0.66 & 0.20 & 2.27 & 0.30 \\
\hline MB.C. 22620.2 & 22.66 & 6.53 & 9.80 & 5.73 & 7.33 & 0.29 & 0.67 & 0.25 & 2.18 & 0.25 \\
\hline MB.C.22622.1 & 21.53 & 6.22 & 9.85 & 5.46 & 7.25 & 0.29 & 0.63 & 0.25 & 2.27 & 0.26 \\
\hline \multirow[t]{10}{*}{ MB.C.22639 } & 26.71 & 7.24 & 12.24 & 6.26 & 8.60 & 0.27 & 0.59 & 0.23 & 2.17 & 0.30 \\
\hline & 18.12 & 5.37 & 8.22 & 4.90 & 5.96 & 0.30 & 0.65 & 0.27 & 2.22 & 0.28 \\
\hline & 12.16 & 3.61 & 5.30 & 4.01 & 4.18 & 0.30 & 0.72 & 0.33 & 2.32 & 0.16 \\
\hline & 7.98 & 2.27 & 3.15 & 2.97 & 2.54 & 0.28 & 0.72 & 0.37 & 2.15 & 0.19 \\
\hline & 5.44 & 1.58 & 1.86 & 2.44 & 1.60 & 0.29 & 0.85 & 0.45 & 2.01 & 0.14 \\
\hline & 3.84 & 1.18 & 1.14 & 1.86 & 1.04 & 0.31 & 1.04 & 0.49 & 1.88 & 0.08 \\
\hline & 2.80 & 0.95 & 0.84 & 1.34 & 0.77 & 0.34 & 1.13 & 0.48 & 1.91 & 0.08 \\
\hline & 2.03 & 0.74 & 0.62 & 0.96 & 0.56 & 0.37 & 1.20 & 0.47 & 1.91 & 0.09 \\
\hline & 1.47 & 0.66 & 0.45 & 0.62 & 0.41 & 0.45 & 1.47 & 0.42 & 1.94 & 0.09 \\
\hline & 1.05 & 0.53 & 0.39 & 0.32 & 0.34 & 0.51 & 1.37 & 0.30 & 2.19 & 0.13 \\
\hline \multicolumn{11}{|c|}{ Cymaclymenia subvexa $\mathrm{n}$. sp. } \\
\hline MB.C. 22658 & 39.17 & 12.14 & 18.06 & 9.00 & 12.90 & 0.31 & 0.67 & 0.23 & 2.22 & 0.29 \\
\hline \multirow[t]{11}{*}{ MB.C. 22675} & 42.25 & 12.84 & 18.94 & 10.98 & 14.14 & 0.30 & 0.68 & 0.26 & 2.26 & 0.25 \\
\hline & 28.12 & 9.25 & 12.34 & 6.88 & 9.08 & 0.33 & 0.75 & 0.24 & 2.18 & 0.26 \\
\hline & 19.04 & 6.57 & 8.90 & 4.64 & 6.67 & 0.35 & 0.74 & 0.24 & 2.37 & 0.25 \\
\hline & 12.37 & 4.58 & 5.50 & 3.43 & 4.15 & 0.37 & 0.83 & 0.28 & 2.26 & 0.25 \\
\hline & 8.22 & 2.92 & 3.44 & 2.83 & 2.70 & 0.36 & 0.85 & 0.34 & 2.22 & 0.21 \\
\hline & 5.52 & 1.74 & 1.96 & 2.21 & 1.62 & 0.31 & 0.89 & 0.40 & 2.01 & 0.17 \\
\hline & 3.90 & 1.37 & 1.36 & 1.65 & 1.11 & 0.35 & 1.01 & 0.42 & 1.96 & 0.18 \\
\hline & 2.79 & 0.94 & 0.89 & 1.25 & 0.78 & 0.34 & 1.06 & 0.45 & 1.93 & 0.12 \\
\hline & 2.01 & 0.79 & 0.65 & 0.85 & 0.57 & 0.39 & 1.22 & 0.43 & 1.94 & 0.13 \\
\hline & 1.44 & 0.62 & 0.50 & 0.60 & 0.45 & 0.43 & 1.24 & 0.42 & 2.10 & 0.11 \\
\hline & 0.99 & 0.53 & 0.34 & 0.32 & 0.30 & 0.53 & 1.55 & 0.32 & 2.07 & 0.11 \\
\hline \multicolumn{11}{|c|}{ Cymaclymenia formosa n. sp. } \\
\hline MB.C.22609.1 & 52.90 & 15.16 & 23.40 & 12.60 & 17.58 & 0.29 & 0.65 & 0.24 & 2.24 & 0.25 \\
\hline MB.C.22669.1 & 57.71 & 18.25 & 27.33 & 12.52 & 18.62 & 0.32 & 0.67 & 0.22 & 2.18 & 0.32 \\
\hline MB.C. 22649.2 & 51.22 & 15.22 & 23.43 & 10.38 & 16.90 & 0.30 & 0.65 & 0.20 & 2.23 & 0.28 \\
\hline MB.C. 22669.4 & 50.29 & 15.16 & 22.73 & 12.02 & 15.42 & 0.30 & 0.67 & 0.24 & 2.08 & 0.32 \\
\hline MB.C. 22669.2 & 46.87 & 15.91 & 22.05 & 11.20 & 14.94 & 0.34 & 0.72 & 0.24 & 2.15 & 0.32 \\
\hline MB.C. 22669.3 & 42.47 & 13.14 & 19.20 & 9.70 & 13.66 & 0.31 & 0.68 & 0.23 & 2.17 & 0.29 \\
\hline MB.C.22649.1 & 35.39 & 10.74 & 16.42 & 8.38 & 12.37 & 0.30 & 0.65 & 0.24 & 2.36 & 0.25 \\
\hline \multirow[t]{12}{*}{ MB.C.22649.3 } & 43.43 & 13.55 & 20.68 & 8.87 & 14.92 & 0.31 & 0.66 & 0.20 & 2.32 & 0.28 \\
\hline & 28.51 & 9.43 & 13.88 & 6.01 & 10.21 & 0.33 & 0.68 & 0.21 & 2.43 & 0.26 \\
\hline & 18.31 & 6.49 & 8.62 & 4.57 & 6.50 & 0.35 & 0.75 & 0.25 & 2.40 & 0.25 \\
\hline & 11.81 & 3.88 & 5.11 & 3.68 & 3.97 & 0.33 & 0.76 & 0.31 & 2.27 & 0.22 \\
\hline & 7.83 & 2.65 & 3.02 & 2.99 & 2.47 & 0.34 & 0.88 & 0.38 & 2.13 & 0.18 \\
\hline & 5.37 & 1.73 & 1.82 & 2.37 & 1.57 & 0.32 & 0.95 & 0.44 & 2.00 & 0.14 \\
\hline & 3.80 & 1.29 & 1.18 & 1.80 & 1.04 & 0.34 & 1.09 & 0.47 & 1.90 & 0.12 \\
\hline & 2.76 & 1.04 & 0.82 & 1.34 & 0.72 & 0.38 & 1.26 & 0.48 & 1.83 & 0.13 \\
\hline & 2.04 & 0.81 & 0.60 & 0.98 & 0.51 & 0.40 & 1.36 & 0.48 & 1.78 & 0.14 \\
\hline & 1.53 & 0.63 & 0.46 & 0.73 & 0.40 & 0.41 & 1.36 & 0.48 & 1.83 & 0.14 \\
\hline & 1.13 & 0.53 & 0.33 & 0.48 & 0.29 & 0.47 & 1.60 & 0.42 & 1.79 & 0.13 \\
\hline & 0.84 & 0.50 & 0.32 & 0.25 & 0.24 & 0.59 & 1.54 & 0.30 & 1.93 & 0.26 \\
\hline
\end{tabular}


Table A2. Continued.

\begin{tabular}{|c|c|c|c|c|c|c|c|c|c|c|}
\hline & $\mathrm{dm}$ & ww & wh & uw & ah & $\mathrm{ww} / \mathrm{dm}$ & ww/wh & $\mathrm{uw} / \mathrm{dm}$ & WER & IZR \\
\hline \multicolumn{11}{|c|}{ Cymaclymenia lambidia $\mathrm{n}$. sp. } \\
\hline MB.C.22632.1 & 50.69 & 16.98 & 23.90 & 10.21 & 16.24 & 0.33 & 0.71 & 0.20 & 2.17 & 0.32 \\
\hline MB.C. 22604.3 & 48.25 & 17.73 & 23.76 & 9.97 & 17.08 & 0.37 & 0.75 & 0.21 & 2.40 & 0.28 \\
\hline MB.C.22632.2 & 41.33 & 16.95 & 19.00 & 7.90 & 12.71 & 0.41 & 0.89 & 0.19 & 2.09 & 0.33 \\
\hline MB.C.22604.1 & 33.22 & 12.79 & 15.88 & 7.69 & 11.37 & 0.39 & 0.81 & 0.23 & 2.31 & 0.28 \\
\hline MB.C.22604.2 & 31.73 & 12.46 & 14.86 & 6.47 & 10.87 & 0.39 & 0.84 & 0.20 & 2.31 & 0.27 \\
\hline \multirow[t]{12}{*}{ MB.C.22632.3 } & 43.58 & 15.76 & 20.26 & 9.36 & 14.16 & 0.36 & 0.78 & 0.21 & 2.19 & 0.30 \\
\hline & 29.42 & 12.65 & 13.96 & 6.07 & 9.76 & 0.43 & 0.91 & 0.21 & 2.24 & 0.30 \\
\hline & 19.66 & 8.61 & 9.40 & 4.24 & 6.64 & 0.44 & 0.92 & 0.22 & 2.28 & 0.29 \\
\hline & 13.02 & 6.36 & 6.03 & 3.33 & 4.16 & 0.49 & 1.06 & 0.26 & 2.16 & 0.31 \\
\hline & 8.87 & 4.37 & 3.66 & 2.83 & 2.71 & 0.49 & 1.19 & 0.32 & 2.07 & 0.26 \\
\hline & 6.16 & 3.13 & 2.37 & 2.17 & 1.81 & 0.51 & 1.32 & 0.35 & 2.01 & 0.24 \\
\hline & 4.35 & 2.29 & 1.61 & 1.69 & 1.29 & 0.53 & 1.42 & 0.39 & 2.02 & 0.20 \\
\hline & 3.06 & 1.52 & 1.05 & 1.27 & 0.88 & 0.50 & 1.46 & 0.42 & 1.97 & 0.16 \\
\hline & 2.18 & 1.16 & 0.74 & 0.92 & 0.56 & 0.53 & 1.56 & 0.42 & 1.81 & 0.24 \\
\hline & 1.62 & 0.76 & 0.51 & 0.65 & 0.44 & 0.47 & 1.48 & 0.40 & 1.87 & 0.15 \\
\hline & 1.18 & 0.64 & 0.46 & 0.41 & 0.39 & 0.54 & 1.40 & 0.35 & 2.23 & 0.14 \\
\hline & 0.79 & 0.50 & 0.32 & 0.21 & 0.24 & 0.63 & 1.57 & 0.27 & 2.08 & 0.24 \\
\hline \multicolumn{11}{|c|}{ Cymaclymenia serotina $\mathrm{n}$. sp. } \\
\hline MB.C.22605.1 & 42.74 & 12.75 & 20.40 & 9.07 & 15.10 & 0.30 & 0.63 & 0.21 & 2.39 & 0.26 \\
\hline MB.C. 22605.2 & 22.95 & 8.23 & 10.64 & 5.72 & 8.40 & 0.36 & 0.77 & 0.25 & 2.49 & 0.21 \\
\hline MB.C. 22605.3 & 19.10 & 6.94 & 8.55 & 5.17 & 6.81 & 0.36 & 0.81 & 0.27 & 2.42 & 0.20 \\
\hline \multicolumn{11}{|c|}{ Cymaclymenia aulax $\mathrm{n} . \mathrm{sp}$. } \\
\hline MB.C. 22651 & 43.05 & 12.15 & 18.55 & 11.55 & 13.50 & 0.28 & 0.65 & 0.27 & 2.12 & 0.27 \\
\hline CYM580 & 30.54 & & 14.70 & 7.90 & 10.70 & & & 0.26 & 2.37 & 0.27 \\
\hline \multicolumn{11}{|c|}{ Cymaclymenia carnata n. sp. } \\
\hline \multirow[t]{12}{*}{ MB.C.22654 } & 47.93 & 19.90 & 22.37 & 10.58 & 15.85 & 0.42 & 0.89 & 0.22 & 2.23 & 0.29 \\
\hline & 32.08 & 15.38 & 14.99 & 7.01 & 10.48 & 0.48 & 1.03 & 0.22 & 2.21 & 0.30 \\
\hline & 21.60 & 11.89 & 10.09 & 4.90 & 7.12 & 0.55 & 1.18 & 0.23 & 2.22 & 0.29 \\
\hline & 14.49 & 9.07 & 6.62 & 3.65 & 4.63 & 0.63 & 1.37 & 0.25 & 2.16 & 0.30 \\
\hline & 9.85 & 6.51 & 4.22 & 2.78 & 3.03 & 0.66 & 1.54 & 0.28 & 2.09 & 0.28 \\
\hline & 6.82 & 4.69 & 2.86 & 2.10 & 2.08 & 0.69 & 1.64 & 0.31 & 2.07 & 0.27 \\
\hline & 4.74 & 3.14 & 1.86 & 1.69 & 1.36 & 0.66 & 1.68 & 0.36 & 1.96 & 0.27 \\
\hline & 3.39 & 2.22 & 1.19 & 1.36 & 0.90 & 0.65 & 1.86 & 0.40 & 1.86 & 0.24 \\
\hline & 2.48 & 1.39 & 0.84 & 1.02 & 0.63 & 0.56 & 1.66 & 0.41 & 1.79 & 0.25 \\
\hline & 1.86 & 0.99 & 0.62 & 0.76 & 0.50 & 0.53 & 1.58 & 0.41 & 1.87 & 0.20 \\
\hline & 1.36 & 0.76 & 0.47 & 0.54 & 0.38 & 0.56 & 1.61 & 0.40 & 1.95 & 0.18 \\
\hline & 0.97 & 0.63 & 0.35 & 0.24 & 0.31 & 0.65 & 1.80 & 0.25 & 2.16 & 0.11 \\
\hline \multicolumn{11}{|c|}{ Cymaclymenia involvens Lange, 1929} \\
\hline MB.C.3695 & 27.49 & 9.86 & 13.10 & 5.98 & 9.60 & 0.36 & 0.75 & 0.22 & 2.36 & 0.27 \\
\hline MB.C.3696 & 40.92 & 15.24 & 20.09 & 8.18 & & 0.37 & 0.76 & 0.20 & & \\
\hline MB.C.22698 & 30.06 & 11.60 & 14.68 & 6.26 & & 0.39 & 0.79 & 0.21 & & \\
\hline MB.C.22699 & 26.17 & 10.12 & 12.07 & 4.62 & & 0.39 & 0.84 & 0.18 & & \\
\hline \multirow[t]{8}{*}{ MB.C.22696 } & 42.24 & 17.09 & 20.82 & 8.01 & 14.49 & 0.40 & 0.82 & 0.19 & 2.32 & 0.30 \\
\hline & 27.76 & 11.83 & 13.42 & 5.28 & 9.26 & 0.43 & 0.88 & 0.19 & 2.25 & 0.31 \\
\hline & 18.50 & 8.22 & 9.06 & 3.75 & 6.32 & 0.44 & 0.91 & 0.20 & 2.31 & 0.30 \\
\hline & 12.17 & 5.77 & 5.69 & 2.95 & 4.13 & 0.47 & 1.01 & 0.24 & 2.29 & 0.28 \\
\hline & 8.05 & 4.26 & 3.53 & 2.36 & 2.86 & 0.53 & 1.21 & 0.29 & 2.41 & 0.19 \\
\hline & 5.19 & 2.86 & 2.16 & 1.68 & 1.69 & 0.55 & 1.32 & 0.32 & 2.20 & 0.22 \\
\hline & 3.49 & 2.00 & 1.34 & 1.21 & 1.14 & 0.57 & 1.49 & 0.34 & 2.21 & 0.15 \\
\hline & 2.35 & 1.31 & 0.95 & & 0.77 & 0.56 & 1.38 & & 2.22 & 0.19 \\
\hline
\end{tabular}


Table A2. Continued.

\begin{tabular}{|c|c|c|c|c|c|c|c|c|c|c|}
\hline & $\mathrm{dm}$ & ww & wh & uw & ah & $\mathrm{ww} / \mathrm{dm}$ & ww/wh & $\mathrm{uw} / \mathrm{dm}$ & WER & IZR \\
\hline \multicolumn{11}{|c|}{ Cymaclymenia costellata (Münster, 1832) } \\
\hline MB.C.4179 & 52.20 & 14.90 & 22.10 & 15.90 & 16.20 & 0.29 & 0.67 & 0.30 & 2.10 & 0.27 \\
\hline MB.C. 22700 & 50.30 & 14.80 & 22.60 & 12.70 & 15.70 & 0.29 & 0.65 & 0.25 & 2.11 & 0.31 \\
\hline MB.C.22692 & 45.90 & 16.00 & 20.50 & 10.40 & 14.10 & 0.35 & 0.78 & 0.23 & 2.08 & 0.31 \\
\hline MB.C. 22697 & 45.50 & 14.20 & 20.70 & 10.70 & 14.80 & 0.31 & 0.69 & 0.24 & 2.20 & 0.29 \\
\hline MB.C.22701 & 40.00 & 12.80 & 17.90 & 10.40 & 12.50 & 0.32 & 0.72 & 0.26 & 2.12 & 0.30 \\
\hline MB.C.4185 & 37.60 & 11.20 & 16.90 & 8.50 & 11.80 & 0.30 & 0.66 & 0.23 & 2.12 & 0.30 \\
\hline MB.C.22695.1 & 31.90 & 11.40 & 14.60 & 7.90 & 10.20 & 0.36 & 0.78 & 0.25 & 2.16 & 0.30 \\
\hline \multirow[t]{6}{*}{ MB.C.22693 } & 51.14 & 18.57 & 23.85 & 10.71 & 16.39 & 0.36 & 0.78 & 0.21 & 2.17 & 0.31 \\
\hline & 34.74 & 13.01 & 16.59 & 6.98 & 11.64 & 0.37 & 0.78 & 0.20 & 2.26 & 0.30 \\
\hline & 23.10 & 9.61 & 11.18 & 5.14 & 8.07 & 0.42 & 0.86 & 0.22 & 2.36 & 0.28 \\
\hline & 15.03 & 6.07 & 6.78 & 3.97 & 5.03 & 0.40 & 0.90 & 0.26 & 2.26 & 0.26 \\
\hline & 10.00 & 4.06 & 4.28 & 3.02 & 3.26 & 0.41 & 0.95 & 0.30 & 2.20 & 0.24 \\
\hline & 6.75 & 2.69 & 2.71 & 2.29 & 2.20 & 0.40 & 0.99 & 0.34 & 2.21 & 0.19 \\
\hline \multirow[t]{8}{*}{ MB.C.22695.3 } & 11.77 & 4.46 & 4.91 & 3.71 & 3.97 & 0.38 & 0.91 & 0.32 & 2.28 & 0.19 \\
\hline & 7.80 & 3.07 & 3.15 & 2.70 & 2.57 & 0.39 & 0.97 & 0.35 & 2.22 & 0.19 \\
\hline & 5.24 & 2.11 & 1.95 & 2.00 & 1.61 & 0.40 & 1.08 & 0.38 & 2.09 & 0.17 \\
\hline & 3.63 & 1.55 & 1.29 & 1.49 & 1.09 & 0.43 & 1.21 & 0.41 & 2.04 & 0.16 \\
\hline & 2.54 & 1.06 & 0.85 & 1.09 & 0.76 & 0.42 & 1.24 & 0.43 & 2.03 & 0.11 \\
\hline & 1.78 & 0.79 & 0.60 & 0.77 & 0.53 & 0.44 & 1.32 & 0.43 & 2.01 & 0.12 \\
\hline & 1.26 & 0.67 & 0.42 & 0.51 & 0.35 & 0.54 & 1.61 & 0.41 & 1.94 & 0.15 \\
\hline & 0.90 & 0.55 & 0.33 & 0.33 & 0.25 & 0.61 & 1.69 & 0.36 & 1.90 & 0.24 \\
\hline \multicolumn{11}{|c|}{ Postclymenia calceola $\mathrm{n}$. sp. } \\
\hline MB.C. 22662.2 & 56.66 & 16.23 & 23.30 & 17.66 & 17.31 & 0.29 & 0.70 & 0.31 & 2.07 & 0.26 \\
\hline MB.C.22662.1 & 54.28 & 14.44 & 24.10 & 16.80 & 17.30 & 0.27 & 0.60 & 0.31 & 2.15 & 0.28 \\
\hline MB.C. 22662.3 & 47.54 & 13.52 & 19.70 & 14.24 & 15.02 & 0.28 & 0.69 & 0.30 & 2.14 & 0.24 \\
\hline MB.C.22663.1 & 32.33 & 8.45 & 12.55 & 12.35 & 9.81 & 0.26 & 0.67 & 0.38 & 2.06 & 0.22 \\
\hline MB.C.22663.2 & 30.17 & 7.81 & 9.90 & 12.18 & 8.56 & 0.26 & 0.79 & 0.40 & 1.95 & 0.14 \\
\hline \multirow[t]{10}{*}{ MB.C.9302.2 } & 42.41 & 12.63 & 17.23 & 14.09 & 12.55 & 0.30 & 0.73 & 0.33 & 2.02 & 0.27 \\
\hline & 29.86 & 9.32 & 11.10 & 10.81 & 8.63 & 0.31 & 0.84 & 0.36 & 1.98 & 0.22 \\
\hline & 21.23 & 6.05 & 7.95 & 7.87 & 6.04 & 0.28 & 0.76 & 0.37 & 1.95 & 0.24 \\
\hline & 15.19 & 4.69 & 5.41 & 5.88 & 4.23 & 0.31 & 0.87 & 0.39 & 1.92 & 0.22 \\
\hline & 10.96 & 3.30 & 3.89 & 4.37 & 3.10 & 0.30 & 0.85 & 0.40 & 1.95 & 0.20 \\
\hline & 7.85 & 2.32 & 2.69 & 3.24 & 2.17 & 0.29 & 0.86 & 0.41 & 1.91 & 0.19 \\
\hline & 5.69 & 1.77 & 1.92 & 2.48 & 1.59 & 0.31 & 0.92 & 0.44 & 1.93 & 0.17 \\
\hline & 4.09 & 1.28 & 1.29 & 1.87 & 1.06 & 0.31 & 1.00 & 0.46 & 1.82 & 0.17 \\
\hline & 3.03 & 0.94 & 0.94 & 1.33 & 0.79 & 0.31 & 1.00 & 0.44 & 1.83 & 0.16 \\
\hline & 2.24 & 0.68 & 0.77 & 0.88 & 0.66 & 0.30 & 0.89 & 0.39 & 2.02 & 0.14 \\
\hline
\end{tabular}

